\title{
Peacekeepers Facilitating Human Rights Violations: The Liability of the Dutch State in the Mothers of Srebrenica Cases
}

\section{Cedric Ryngaert ${ }^{1}$}

\begin{abstract}
This article provides a critical reading of the judgments of The Hague District Court and especially The Hague Court of Appeal in the case of Mothers of Srebrenica $v$. the State of the Netherlands, which concerned the liability in tort of the Dutch State for facilitating the massacre of Bosnian Muslims in 1995. It engages with the courts' considerations regarding the attribution of conduct to the State in UN peacekeeping operations, the extraterritorial application of human rights treaties, the State obligation to prevent genocide, and the State's liability for damages. While not fully agreeing with the courts' argumentation, the author concludes that the judgments contribute to the refinement of the law and practice of State responsibility in respect of wrongful acts committed in complex multinational peace operations.
\end{abstract}

Keywords Liability · Responsibility · United Nations · Peacekeeping · Member states · Attribution

\section{Introduction}

In the case of Mothers of Srebrenica v. the State of the Netherlands, the Court of Appeal of The Hague decided on 27 June 2017 that the State of the Netherlands committed wrongful acts by (a) facilitating, in July 1995, the separation of male

Cedric Ryngaert

C.M.J.Ryngaert@uu.nl

1 Professor of Public International Law, Department of Law, Utrecht University, Utrecht, The Netherlands 
Bosnian Muslim refugees by the Bosnian Serbs in a mini safe area created close to Srebrenica, as well as (b) evacuating the male refugees from the compound of the Dutch UN battalion (Dutchbat). ${ }^{1}$ After being handed over to the Bosnian Serb militia led by Ratko Mladić, most of these refugees were killed. According to the Court, Dutchbat was aware of the serious risk of the refugees being tortured, treated inhumanely or degradingly, or executed, and nevertheless went on to evacuate them from the mini safe area. However, as the Court considered that these refugees would have been killed anyway by the Bosnian Serbs, even if Dutchbat had refrained from the wrongful separation, it dismissed the next-of-kin's claims for damages. In addition, holding that it was uncertain whether the men on the compound would have survived had they been kept there, the Court ruled that the next-of-kin would be entitled to only $30 \%$ of the damage they had suffered. On 20 September 2017, the State filed a cassation appeal against the Court of Appeal's decision, as a result of which the Dutch Supreme Court will now hear the case.

The Court of Appeal's judgment in Mothers of Srebrenica contributes to a better understanding of the question of attribution of conduct in complex UN peace operations, and of the circumstances under which wrongful acts may be committed. It builds on the seminal (and related) Dutch cases of Mustafic and Nuhanovic v. the State of Netherlands (2008-2013), in which the courts held the Dutch State liable for the evacuation from the same Dutchbat compound of a Bosnian electrician and interpreter working for Dutchbat. ${ }^{2}$ However, the judgment differs considerably, both in terms of reasoning and actual outcome, from the first instance judgment rendered by the District Court of The Hague in 2014, commented previously in this Review. ${ }^{3}$ Even if both courts held the State (partly) liable, they did so on other grounds. ${ }^{4}$ This note explains the main differences between the first instance and appeal judgments in Mothers of Srebrenica. It focuses on the four main issues of (international) legal relevance addressed by the courts: (1) the attribution of conduct to the State in UN peacekeeping operations; (2) the extraterritorial application of human rights treaties; (3) the State obligation to prevent genocide; (4) the State's

\footnotetext{
${ }^{1}$ Court of Appeal of The Hague, $X$ and Stichting Mothers of Srebrenica $v$. State of the Netherlands, judgment of 27 June 2017, ECLI:NL:GHDHA:2017:1761. The ECLI number of the (unofficial) English translation is ECLI:NL:GHDHA:2017:3376, available at <http://deeplink.rechtspraak.nl/uitspraak?id= ECLI:NL:GHDHA:2017:3376>. The translation of the judgment is reproduced in the appendix to this annotation.

${ }^{2}$ Final decision by Dutch Supreme Court, State of the Netherlands v. Mustafić, State of the Netherlands v. Nuhanović, judgments of 6 September 2013, ECLI:NL:HR:2013:BZ9228; ECLI:NL:HR:2013:BZ9225 (decisions available in English). Note that in Mothers of Srebrenica the Dutch Supreme Court had earlier dismissed the parallel case against the UN for reason of immunity, a decision upheld by the European Court of Human Rights (ECtHR) in 2013. Supreme Court, X and Stichting Mothers of Srebrenica v. State of the Netherlands and the United Nations, judgment of 13 April 2012, ECLI:NL:HR:2012:BW1999; ECtHR, Stichting Mothers of Srebrenica v. State of the Netherlands, Appl. No. 65542/12, judgment of 27 June 2013.

3 District Court of The Hague, $X$ and Stichting Mothers of Srebrenica $v$. State of the Netherlands and the United Nations, judgment of 16 July 2014, ECLI:NL:RBDHA:2014:8748, ECLI:NL:RBDHA:2014:8562. This decision is available in English. District Court of The Hague, Mothers of Srebrenica et al. v. State of the Netherlands, judgment of 16 July 2014-Introductory note by C. Ryngaert, 61 NILR (2014) pp. 365-454.

4 Accordingly, the Court of Appeal quashed the District Court's judgment and decided anew.
} 
liability for damages. ${ }^{5}$ These issues are likely to be salient for any peace operation deployed in an environment where gross human rights violations, including genocide, are committed by one or more parties.

\section{Attribution of Conduct in UN Peacekeeping Operations}

At the first instance, the District Court determined that the question of attribution of conduct in UN peacekeeping operations must be answered according to public international law, and-like the Dutch Supreme Court's decisions in Mustafić and Nuhanović - considered the 'effective control' standard laid down in Article 7 of the Draft Articles on the Responsibility of International Organizations for Internationally Wrongful Acts (DARIO 2011) to be the appropriate yardstick to attribute conduct to the State and/or the UN. On that basis, it went on to attribute a number of acts which occurred in the vicinity of Srebrenica to the Dutch State. ${ }^{6}$ According to the District Court, in UN peacekeeping operations, attribution to the State would be a function of the State acting ultra vires, i.e., if the national military force, after having transferred command and control to the UN, goes on 'to act beyond the authority given it by the UN or on its own initiative acts against the instructions of the UN'? Because Dutchbat's actions were held to be in conflict with the orders given by the $\mathrm{UN}$-Dutch government instructions were considered to interfere with the management of the operational implementation of the mandate by Dutchbatthose actions would automatically be attributed to the State. This reasoning however appeared to misconstrue the notion of ultra vires in the law of responsibility. Notably, pursuant to Article 8 DARIO, also conduct which exceeds the authority of an organ or agent of an international organization or contravenes instructions (ultra vires conduct), is considered an act of the organization under international law 'if the organ or agent acts in an official capacity and within the overall functions of that organization'. Such conduct does not suddenly become an act of the State whose troops acted as organs or agents of the organization.

The Court of Appeal has corrected this mistake. Also relying on the DARIO, it has limited attribution to the State to the situation of troops acting truly outside the official capacity and overall functions of the UN, rather than derogating from the UN's instructions. In addition, the Court espoused a narrow interpretation of the terms 'acts in an official capacity' and 'overall functions of the UN' of Article 8 DARIO. Applying the presumption that the UN normally exercises overall control over UN peacekeepers, it ruled that operational combat actions belong to the powers and tasks of the UN peacekeepers. Accordingly, in the Court's opinion, the Netherlands had no control whatsoever over estimations of the reality of the

\footnotetext{
5 Note that the Mothers of Srebrenica judgments against the State are partly based on common Dutch tort law, laid down in Art. 6:162 of the Dutch Civil Code, and partly on international law given the international nature of the abuses committed around Srebrenica (genocide and gross human rights violations) and the presence of a UN troop contingent.

6 District Court, para. 4.30.

7 Ibid., para. 4.57.
} 
dangers, over reinforcements, or over exchanging fire with the Bosnian Serbs. Control over these decisions instead rested with the UN.

In terms of attribution, this made a major difference. The District Court, relying in particular on specific 'instructions' given by the Netherlands which arguably interfered with the UN mandate, determined that the State had effective control over a host of acts that took place after the fall of Srebrenica on 10 July 1995, e.g., Dutchbat surrendering weapons to the Serbs, providing humanitarian assistance to the refugees, and preparing their evacuation. The Court of Appeal, in contrast, espousing the narrow interpretation of Article 8 DARIO, attributed far fewer acts to the State. It pointed out that the so-called 'instructions' given by the State were only non-binding communications, which could not lead to a finding of effective control of the State over specific actions. The Court only found 'effective control' by the State over a number of actions taken from the evening of 11 July 1995 onwards, when a transitional period started after the decision of the State and the UN to evacuate Dutchbat and the Bosnian Muslim population which had sought refuge in the mini safe area created outside the compound of Dutchbat. It was only during this period that the State had effective control over Dutchbat's acts concerning humanitarian assistance to, and the evacuation of refugees in the mini safe area.

\section{The Extraterritorial Application of Human Rights Treaties}

The range of acts attributable to the State pursuant to the District Court's model may be much wider than the range of acts attributable to the State under the Court of Appeal's model. Ultimately, however, the District Court found the State liable (responsible in international law terms) in respect of only one act, namely the act of carrying off men from the compound who were then killed by the Bosnian Serbs. The Court of Appeal, for its part, while seemingly approaching attribution narrowly, established that the State committed wrongful acts in two situations, not only when carrying off the men from the compound but also when separating the men queuing for the buses that would take them away from the mini safe area, i.e., outside the compound. The District Court did not establish liability for any acts committed outside the compound, even if such acts had been attributed to the State.

The discrepancy between the large number of acts which the District Court attributed to the State and the fact that the State was liable for only one act, can be explained by the workings of the concept of 'jurisdiction' in human rights law. Relying on the ECtHR's judgment in Al-Skeini (2011), which required the exercise of 'public powers' by the State in the form of 'executive or judicial functions' for an individual to be within the jurisdiction of the State for purposes of the extraterritorial application of the European Convention on Human Rights (ECHR), ${ }^{8}$ the District Court stated that 'by means of Dutchbat the State was only able to supervise observance of the human rights anchored in the ECHR and ICCPR vis-à-vis those persons who as of the fall of Srebrenica were in the compound', and that 'the State was not able to do this for the populace of the safe area prior to the fall of Srebrenica and even less after that vis-à-vis the refugees in the

\footnotetext{
${ }^{8}$ ECtHR, Al-Skeini and Others v. United Kingdom, Appl. No. 55721/07, judgment of 7 July 2011.
} 
mini safe area that lay beyond the compound or beyond the mini safe area' 9 Accordingly, the State only had human rights obligations vis-à-vis refugees on the compound, and not vis-à-vis refugees outside the compound, regardless of whether relevant conduct could be attributed to the State. ${ }^{10}$

The Court of Appeal appeared to concur with the District Court, where it held, relying on the Supreme Court's judgment in Mustafić and Nuhanovic, that the State had jurisdiction over the compound in the sense of Article 1 ECHR and Article 2.1 of the International Covenant on Civil and Political Rights (ICCPR). However, this cannot explain why the Court of Appeal then went on to consider acts carried out by Dutchbat outside the compound-Dutchbat facilitating the separation of the men queuing for the buses in the mini safe area-to be wrongful. The only explanation appears to be that jurisdiction is in the end not decisive for the determination of the wrongfulness of an act committed extraterritorially. This appears to flow from the Court's observation that even if the ECHR and ICCPR provisions were not to apply due to the absence of jurisdiction, this would not make a difference for the actions at bar. The Court of Appeal reached this conclusion by reasoning that the (substantive) norms borrowed from the ECHR and the ICCPR are part of Dutch law anyway, in the sense that a breach of those norms is to be considered as a violation of the duty of care under Dutch tort law. ${ }^{11}$ This is a defensible position. The question is indeed not whether the Dutch State owed human rights obligations to the individuals around Srebrenica, but rather whether Dutchbat's actions constituted an unlawful act according to the law of the Netherlands. The District Court had earlier held that the agreement between the Netherlands and the UN intending the Dutch battalion to function under the command structure of the UN in Bosnia 'is governed by the law of The Netherlands since it is The Netherlands that has the distinctive characteristic of putting its troops at the disposal of the UN and there is nothing to show that the agreement is more closely connected to any other country not even Bosnia-Herzegovina whither Dutchbat was sent'. ${ }^{12}$ On appeal, it was not disputed by the parties that Dutch law was the applicable law. When Dutchbat's conduct is directly reviewed in light of Dutch law, there is no need to consider whether the relevant individuals fall within the Netherlands' jurisdiction: as soon as such conduct is attributed to the State, it can be subjected to a substantive law review. As the District Court's judgment demonstrates, a jurisdictional analysis can only serve to restrict the number of actions subject to such a review, to the detriment of the individuals concerned. For that matter, carrying out such a limiting analysis on the basis of the ECHR appears to be in tension with Article 53 ECHR, pursuant to which nothing in the ECHR 'shall be construed as limiting or derogating from any of the human rights and fundamental freedoms which may be ensured under the laws of any High Contracting Party or under any other agreement to which it is a party'. It has been observed that this safeguard clause is of a pro homine nature, in that it ensures that the legal regime

\footnotetext{
9 District Court, para. 4.161.

${ }^{10}$ I have criticized this restrictive reading of the control standard in C. Ryngaert, introductory note, NILR 2014, supra n. 3.

11 Court of Appeal, para. 38.7.

12 District Court, para. 4.26. The Court based this on Art. 4 of the EU Treaty concerning the law applicable to contractual obligations, June 19th 1980, Trb. [= Treaty Series] 1980 No. 156, later changed into Regulation (EC) No. 593/2008 of June 17th 2008 on the law applicable to contractual obligations, OJ 2008 L 177 ('Rome I Regulation').
} 
which is most in favour of the individual applies. ${ }^{13}$ In the case at hand, the favourable legal regime, at least as far as the geographic scope of rights protection is concerned, is Dutch tort law rather than the ECHR.

That Dutch tort law applies does not mean that international human rights law becomes irrelevant, however. In fact, the Dutch law of tort has a remarkably open character and defines a 'wrongful act' as a breach of a right, or an act or omission in violation of a legal duty or of what is proper in societal relations according to unwritten law. ${ }^{14}$ Going by this definition, substantive international human rights law can inform the determination of whether a wrongful act has been committed. Thus, in Mothers of Srebrenica, Dutch courts inquired whether Dutchbat had discharged its obligation to protect the rights to life and physical integrity as laid down in Articles 2 and 3 ECHR and Article 7 ICCPR. ${ }^{15}$ Eventually, they found that Dutchbat had, in some respects, not done so, as they had evacuated the Bosnian refugees, being aware of the serious risk of the refugees being tortured, mistreated, or killed.

\section{The Obligation to Prevent Genocide}

The Srebrenica massacre has been characterized as a genocide by both the International Criminal Tribunal for the former Yugoslavia (ICTY) and the International Court of Justice (ICJ). ${ }^{16}$ Therefore, it is arguable that the international norm requiring that States prevent and punish genocide, laid down in Article 1 of the Genocide Convention, ${ }^{17}$ should also play a role in domestic cases pertaining to the events in Srebrenica. Arguably, a court determination on facilitating the commission of genocide has a particular expressive function, as genocide is 'the crime of crimes ${ }^{18}$ that heaps moral opprobrium on the facilitator in ways that other violations cannot. In non-criminal cases, domestic courts can make a genocide determination in two ways. Either they issue a declaratory judgment stating that the State has infringed its obligation to prevent genocide, or they hold the State liable in tort for infringing that obligation. Both the District Court and the Court of Appeal dismissed the claimants' application for a declaratory judgment, but the District Court-although not the Court of Appeal—held the State liable in tort.

The courts refused to issue a judgment declaring that the State had violated its obligation to prevent genocide, on the grounds that the Genocide Convention only holds between States, ${ }^{19}$ and does not contain specific obligations of prevention, but

\footnotetext{
13 Negishi (2017).

14 Art. 6:162 Dutch Civil Code.

15 See notably District Court, para. 4.176.

16 ICTY, Prosecutor v. Krstić, IT-98-33, judgment of 2 August 2001; ICJ, Application of the Convention on the Prevention and Punishment of the Crime of Genocide (Bosnia and Herzegovina v. Serbia and Montenegro), judgment of 26 February 2007, ICJ Reports 2007, p. 43, para. 430.

17 Convention on the Prevention and Punishment of the Crime of Genocide 1948, 78 UNTS 1021.

18 On 'the crime of crimes': Schabas (2009).

19 District Court, para. 4.164 ('as evidenced by the text of the Convention and the history of how it came about').
} 
only a general conduct obligation to make maximum efforts to prevent genocide, which requires more specific rules. ${ }^{20}$ The decision that the Genocide Convention is not self-executing (does not have direct effect) is in line with other domestic practice. ${ }^{21}$

That the Genocide Convention is not self-executing need not mean, however, that it has no relevance to proceedings like Mothers of Srebrenica: the Convention could well inform the open duty of care norm in Dutch tort law. Thus, when determining whether the State had committed a tort, the District Court set great store by the State's obligation to prevent genocide: it ruled, in the context of the evacuation of the refugees from the compound, that 'Dutchbat must have been aware of a serious risk of the male refugees being killed in a genocide', ${ }^{22}$ and thus, that 'the State is liable for the deportation of the able-bodied men who had been staying at the compound $[\ldots]$ on account of unlawful acts'. ${ }^{23}$ When contextualizing the duty of care through reliance on relevant norms, including international norms, courts need not be hamstrung by the lack of direct effect of such norms. What is more, in giving shape to the duty of care in specific situations, they could even rely on norms that are not formally binding in the first place, ${ }^{24}$ as long as these norms contain relevant precepts on proper conduct.

One may then fail to understand why the Court of Appeal declined to factor in the obligation to prevent genocide in its tort law analysis, and limited itself to the rights to life and physical integrity. ${ }^{25}$ Still, this may be understandable to the extent that the State may have been aware of imminent acts of torture and killings that in all likelihood would be inflicted upon the refugees, but not that these acts would also constitute genocide. ${ }^{26}$ Awareness of genocide would, after all, require awareness of the Bosnian Serbs' intent to destroy, in whole or in part, the Bosnian Muslims as a distinct national, ethnical, racial or religious group, in addition to awareness of the material acts of torture and killings. At the time of the evacuation of the refugees, immediately following the fall of Srebrenica, Dutchbat may possibly not have had such knowledge. Given informational deficits, it is in fact not uncommon for 'facilitators' to be held liable for other crimes than genocide, even if it later turns out that genocide has effectively been committed. In a 2007 Dutch criminal case, for instance, Dutch businessman A., who had sold chemicals to Saddam Hussein that

\footnotetext{
${ }^{20}$ Court of Appeal, para. 34.4.

21 E.g., US, 132 Congressional Record S1377, 19 February 1986 (US Senate making ratification of the Genocide Convention conditional upon the US passing implementing legislation, thereby resisting direct effect of the Genocide Convention). See also Saul (2009).

22 District Court, para. 4.328.

23 District Court, para. 4.332.

24 This can be gleaned from a Dutch court decision on climate change, in which the court held the Dutch State responsible for not doing enough to diminish greenhouse gas emissions, citing the recommendations of climate scientists and a legally non-binding Dutch political commitment to substantially reduce emissions. District Court of The Hague, Urgenda v. State of the Netherlands, judgment of 24 June 2015, ECLI:NL:RBDHA:2015:7145, para. 4.31.

25 In its judgment, the Court of Appeal cross-references the paragraph in which it held that Art. 1 of the Genocide Convention does not have direct effect (paras. 34.1 and 50.1). However, as argued, direct effect of a norm is no requirement for such a norm to be relevant to tort law.

26 The Court of Appeal hints at this in para. 50.1, where it holds that attribution of the actions does not require that there was awareness of the imminent genocide by the Bosnian Serbs during the evacuation.
} 
could (only) be used to make chemical weapons, was convicted for complicity in war crimes committed by the Iraqi regime against the Kurdish population, but not for complicity in genocide, ${ }^{27}$ even if those crimes had been recognized as amounting to genocide. ${ }^{28}$

\section{The State's Liability for Damages}

The consequence of a finding of State liability or responsibility for an unlawful or wrongful act is that the State is put under obligation to provide reparation for the injury caused, which typically means that the State becomes liable for damages vis-à-vis the victims. Thus, at first instance, the District Court held the State liable for damages incurred by the men who had been deported from the Dutchbat compound and had subsequently been killed by the Bosnian Serbs. The District Court held the State fully (100\%) liable as 'it is determined with a sufficient degree of certainty that the able-bodied men staying at the compound would have survived if Dutchbat had not cooperated with their deportation' ${ }^{29}$ The Court of Appeal, however, did not derive from its findings that the State committed unlawful acts by facilitating the separation of the male Bosnian Muslim refugees in the mini safe area, and by evacuating the male refugees from the Dutchbat compound, that the State was necessarily also liable for damages: it could not establish an unambiguous causal link between the State's unlawful acts and the injury suffered by the victims. In particular, the Court refused to hold the State liable for damages with respect to the separation of the refugees in the mini safe area, as these would likely have been killed by the Bosnian Serbs even if Dutchbat had refrained from the wrongful separation. ${ }^{30}$ It held the Dutch State $30 \%$ liable for damages vis-à-vis the next-of-kin of the men on the compound, as these menunlike what the District Court had decided - were held to only have had a $30 \%$ chance of surviving had they been kept there. ${ }^{31}$

The Court of Appeal's decision evinces that holding the State ultimately liable for damages is not obvious. Even if it can be established that the State facilitated violations committed by others (in the case the Bosnian Serbs) and thus acted wrongfully, a causal connection may not, or may only partially, be drawn between that conduct and the damage suffered by the victims or their next-of-kin. Other causal factors may have contributed to the damage, or the damage may have

\footnotetext{
27 Court of Appeal of The Hague, A., judgment of 9 May 2007, ECLI:NL:GHSGR:2007:BA4676. The Court held that it was insufficiently established that the accused, prior to, or at the time of his conduct, disposed of information enabling him to know that he would facilitate genocide by his conduct.

28 E.g., UK Parliament, 'Debate on Kurdish Genocide', House of Commons Hansard vol. 559, 28 February 2013, column 565, https://hansard.parliament.uk/Commons/2013-02-28/debates/ 13022853000002/KurdishGenocide (accessed 21 July 2017).

29 District Court, para. 4.330, adding as follows in para. 4.331: 'Not cooperating with the deportation of the able-bodied men at the compound would in practice have meant that these men would have remained at the compound, together with Dutchbat and the local personnel and MSF personnel who were going to be evacuated along with Dutchbat. The Bosnian Serbs would have been unable to carry these men off and subsequently kill them.'

30 Court of Appeal, para. 64.

31 Court of Appeal, para. 68.
} 
occurred anyway, even absent the State's wrongful act. Given the uncertainty surrounding the contributory factors, there is a whiff of informed guesswork regarding the calculation of the damages to which the victims are entitled. One should thus forgive the next-of-kin for being exasperated by the Court of Appeal's decision that they were entitled to only $30 \%$ of the damage they had suffered, as the victims sent away from the compound were considered to only have had a $30 \%$ chance of survival anyway. Why the Court decided that this chance was $30 \%$, rather than 20 or $40 \%$, remains unexplained. ${ }^{32}$ Yet perhaps it cannot be explained as one cannot possibly know what exactly would have happened had the Bosnian men stayed on the compound.

The only option to do fuller justice to victims' interests would be for the State to be held jointly and severally liable for the damage, assuming that some causal contribution by the State can be established. Joint and several liability means that the State is liable vis-à-vis the victims for $100 \%$ of the damage, and that it is subsequently incumbent on the State to recover from other parties (potentially) liable for the damage. In the case at hand, these parties would be the Bosnian Serb militia which actually committed the massacre, and the United Nations, to which the Court of Appeal had co-attributed, together with the Dutch State, the decision to evacuate the refugees. ${ }^{33}$ However, joint and several liability does not exist in all legal systems, and it is not clear to what extent it exists in international law. ${ }^{34}$ In particular, Article 48 DARIO, which provides that '[w]here an international organization and one or more States or other international organizations are responsible for the same internationally wrongful act, the responsibility of each State or organization may be invoked in relation to that act', adds that this rule is 'without prejudice to any right of recourse that the State or international organization providing reparation may have against the other responsible States or international organizations' ${ }^{35}$ While such a right of recourse may exist against the UN, it is unlikely to exist against the Bosnian Serb militia, which committed another internationally wrongful act, and, for that matter, is no longer in existence. ${ }^{36}$ Therefore, all in all, the Court of Appeal's determination that the State is liable for only $30 \%$ of the damage, while appearing unsatisfactory, is not

\footnotetext{
32 See also the lead editorial of the NRC Handelsblad quality newspaper of 27 June 2017 ('Het leed van Srebrenica is niet uit te drukken in procenten' [The suffering of Srebrenica cannot be expressed in percentages]).

33 Court of Appeal, para. 32.2. See on dual attribution regarding the Srebrenica situation also Nollkaemper (2011); Bakker (2013). See on dual attribution in military operations more generally: Dannenbaum (2015); d'Argent (2014).

34 Noyes and Smith (1988). See on shared responsibility in general: Nollkaemper and Jacobs (20122013).

35 Art. 48(3)(b) DARIO.

36 Moreover, even if it were still in existence, given that the Bosnian Serb militia is a non-state armed group, it is uncertain to what extent its conduct is governed by international liability rules. Still, a relatively far-fetched argument could possibly be made that the militia's conduct can be attributed to the State of Bosnia and Herzegovina, in that the Republika Srpska, one of the constitutional entities of the Bosnian Federation, is the successor of the Bosnian Serb militia. Art. 10 of the ILC Articles on State Responsibility provides that ' $[\mathrm{t}] \mathrm{he}$ conduct of an insurrectional movement which becomes the new government of a State shall be considered an act of that State under international law'.
} 
irrational. What is more, even if (full) damages are not granted, some satisfaction is inherent in a declaratory judgment attesting that the State committed a wrongful act by facilitating human rights violations committed by the Bosnian Serbs. ${ }^{37}$

\section{Concluding Observations}

A 2015 special issue of this Review highlighted the impact of the events in Srebrenica on the development of several fields of international law, including the law of State responsibility. ${ }^{38}$ As the Mothers of Srebrenica judgments of the District Court and the Court of Appeal show, this development is on-going even twenty years down the road. Despite the courts' different legal appreciation of the relevant facts, the judgments contribute to the refinement of the law and practice of State responsibility in respect of wrongful acts committed in complex, out-of-area multinational peace operations for a number of reasons. Most importantly, they further cement the 'effective control' standard of Article 7 DARIO as the applicable standard for attribution of conduct in UN peace operations, and allow for dual attribution to the troop-contributing State and the UN in cases where both are involved in decision-making. The judgments also confirm that States remain bound by international human rights law when conducting extraterritorial operations, as well as that violations of human rights obligations can lead to liability in tort. Finally, they acknowledge the difficulties of determining a responsible State's liability for damages in case responsibility is shared with other actors. They are likely to offer inspiration and even guidance to foreign courts confronted with similar questions, provided obviously that tort cases concerning combat operations brought against the State are considered as justiciable. ${ }^{39}$

Acknowledgements The research which resulted in this publication has been funded by the European Research Council under the Starting Grant Scheme (Proposal 336230-UNIJURIS) and the Dutch Organization for Scientific Research under the VIDI Scheme (No. 016.135.322).

Open Access This article is distributed under the terms of the Creative Commons Attribution 4.0 International License (http://creativecommons.org/licenses/by/4.0/), which permits unrestricted use, distribution, and reproduction in any medium, provided you give appropriate credit to the original author(s) and the source, provide a link to the Creative Commons license, and indicate if changes were made.

\footnotetext{
37 Note that Art. 34 of the ILC Articles on State Responsibility provides that 'reparation for the injury caused by the internationally wrongful act shall take the form of restitution, compensation and satisfaction, either singly or in combination'.

38 NILR 2015 issue 2.

39 This is not self-evident. See United States Foreign Claims Act, 10 USC § 2734 (2006) (excluding damage incurred from combat activities); German Federal Court of Justice, judgment of 2 November 2006, No. III ZR 190/05, BGHZ 169, 348 (excluding compensation under German domestic State tort liability law); Groves v. Commonwealth (1982) 150 CLR 113, para 3; Smith and Others v. the Ministry of Defence [2013] UKSC 41. These cases are discussed in Krieger (2015).
} 


\section{Appendix}

\section{ECLI:NL:GHDHA:2017:3376}

\section{COURT OF APPEAL AT DEN HAAG}

Civil-law sector

Case numbers: 200.158.313/01 and 200.160.317/01

Case number District Court: C/09/295247/HA ZA 07-2973

Judgment on appeal of 27 June 2017

in the case of

1. [appellant 1],

living in [place of residency], Bosnia and Herzegovina,

2. [appellant 2],

living in [place of residency], Bosnia and Herzegovina,

3. [appellant 3],

living in [place of residency], Bosnia and Herzegovina,

4. [appellant 4],

living in [place of residency], Bosnia and Herzegovina,

5. [appellant 5],

living in [place of residency], Bosnia and Herzegovina,

6. [appellant 6],

living in [place of residency], Bosnia and Herzegovina,

7. [appellant 7],

living in [place of residency], Bosnia and Herzegovina,

8. [appellant 8],

living in [place of residency]), Bosnia and Herzegovina,

9. [appellant 9],

living in [place of residency], Bosnia and Herzegovina,

10. [appellant 10],

living in [place of residency], Bosnia and Herzegovina,

11. the Association MOTHERS OF SREBRENICA, registered in Amsterdam,

in the case with case number 200.160.317:

appellants in the principal appeal,

respondents in the cross-appeal,

in the case with case number 200.158.313:

respondents in the principal appeal,

appellants in the cross-appeal,

hereinafter referred to as: the Association et al. (plural), attorney: M.R. Gerritsen, LLM of Haarlem, $\mathrm{v}$.

THE STATE OF THE NETHERLANDS (Ministry of General Affairs, Ministry of Defence and Ministry of Foreign Affairs),

having its seat in The Hague

in the case with case number 200.160.317:

respondent in the principal appeal, 
appellant in the cross-appeal,

in the case with case number 200.158.313:

appellant in the principal appeal,

respondent in the cross-appeal,

hereinafter referred to as: the State,

attorney: G.J.H. Houtzagers, LLM, of The Hague.

\section{Appeal proceedings}

In the case with case number 200.160.317:

1.1 By writ of 14 October 2014, the Association et al. summoned the State to appear in appeal proceedings, moving that the Court of Appeal should reverse the judgment of the District Court of 16 July 2014 in so far as the claims of the Association et al. against the State were dismissed, and that the Court of Appeal, in a new judgment, should allow the claims in their entirety in second instance.

In their statement of appeal (with exhibits) of 7 July 2015, the Association et al. changed their claim and put forward 48 grounds for appeal against the judgment. On 26 January 2016, the State contested these grounds in their defence on appeal, also statement of appeal in cross-appeal, and in turn brought a cross-appeal, referring to the grounds submitted in the case with case number 200.158.313 for the details.

In the case with case number 200.158.313

1.2 By writ of 9 October 2014, the State summoned the Association et al. to appear in appeal proceedings, moving that the Court of Appeal should reverse the judgment of the District Court of 16 July 2014 and dismiss the claims of the Association et al. in their entirety.

In their statement of appeal of 7 July 2015, the State put forward 5 grounds for appeal against the judgment. The Association et al. contested these grounds in their defence on appeal, also statement of appeal in cross-appeal, and in turn brought a cross-appeal referring for the details to the grounds submitted in the case with case number 200.160.137.

Furthermore, in both cases:

1.3 By an instrument of deposit dated 12 September 2016, the Association et al. filed a flash drive containing images. The following documents that had been filed with the District Court before were not filed with the Court of Appeal: the NIOD [Netherlands Institute for War Documentation] (hereinafter: the NIOD) report of 2002, "Srebrenica. Een 'veilig gebied'. Reconstructie, achtergronden, gevolgen en analyses van de val van de Safe area" [Srebrenica. A 'Safe Area'. Reconstruction, backgrounds, consequences and analyses of the fall of the Safe Area], parts I through III (hereinafter: the NIOD report), the Parliamentary Inquiry on Srebrenica: "Missie zonder Vrede" [Mission without Peace], final report submitted to the House of Representatives on 27 January 2003 (Parliamentary Papers II 2002/2003, 28506, nos. 2-3), and the Parliamentary Inquiry on Srebrenica "Missie zonder Vrede", the interviews (Parliamentary Papers II 2002-2003, 28506, no. 5). These documents are public documents and can be consulted via the Internet. In accordance with the manifest wish of both parties, these documents are part of the case files via the public domain.

1.4 On 6 October 2016, the parties had their cases pleaded submitting and referring to memoranda of oral pleading; the Association et al. by M.R. Gerritsen, 
LLM and S.A. van der Sluijs, LLM, attorneys of Haarlem, and the State by G.J.H. Houtzagers, LLM and K. Teuben, LLM, attorneys of The Hague. In conclusion, the parties applied for judgment on appeal in both cases.

\section{Facts acknowledged between the parties on appeal}

In both cases:

2.1 The Court of Appeal considers that the following has been acknowledged as having been argued by one party and not contested or not contested on sufficiently reasoned grounds by the other party, as well as in view of the facts found (in Finding of Fact sub 2 or in Assessment sub 4) by the The Hague District Court and what is not contested or no longer contested on appeal.

2.2 Until 1991, the Socialist Federal Republic of Yugoslavia consisted of six (constituent) republics, i.e. Bosnia and Herzegovina, Croatia, Macedonia, Montenegro, Serbia, and Slovenia. These republics were inhabited by different ethnic groups (Croats, Serbs, Muslims, and others) who formed a majority or a minority in the various republics. Throughout the ages there was both peaceful coexistence and conflict. Conflict always moved along the said ethnic lines.

In 1991, the constituent republics Slovenia and Croatia declared themselves independent of the Socialist Federal Republic of Yugoslavia. Subsequently, fighting erupted in both republics.

2.3 The warring factions in Croatia reached an armistice agreement on 2 January 1992 and accepted a peace plan, which provided for deploying a UN peacekeeping force. The United Nations Security Council (hereinafter: the Security Council), by Resolution 743 of 21 February 1992, formed the United Nations Protection Force (hereinafter: UNPROFOR) with its headquarters in Sarajevo. The Resolution reads, inter alia:

"Concerned that the situation in Yugoslavia continues to constitute a threat to international peace and security (...),

Recalling its primary responsibility under the Charter of the United Nations for the maintenance of international peace and security,

(...)

Convinced that the implementation of the United Nations peace-keeping plan will assist the Conference on Yugoslavia in reaching a peaceful political settlement,

1. Approves the report of the Secretary-General of 15 and 19 February 1992 (...);

2. Decides to establish, under its authority, a United Nations Protection Force in accordance with the above-mentioned report and the United Nations peace-keeping plan, and requests the Secretary-General to take the measures necessary to ensure its earliest possible deployment;

(...)

5. Recalls that, in accordance with paragraph 1 of the United Nations peacekeeping plan, the Force should be an interim arrangement to create the conditions of peace and security required for the negotiation of an overall settlement of the Yugoslav crisis;

(...)

8. Urges all parties and others concerned to comply strictly with the cease-fire arrangements signed at Geneva on 23 November 1991 and at Sarajevo on 2 January 
1992, and to cooperate fully and unconditionally in the implementation of the peace-keeping plan;

9. Demands that all parties and others concerned take all the necessary measures to ensure the safety of the personnel sent by the United Nations (...)"

As from 1 April 1995 UNPROFOR was renamed United Nations Peace Forces (hereinafter: (also) UNPROFOR or UNPF).

2.4 On 3 March 1992, the (constituent) republic of Bosnia and Herzegovina also declared itself independent of the Socialist Federal Republic of Yugoslavia after a referendum. On 27 March 1992, the Bosnian Serbs (the Serbs living in Bosnia) in turn declared themselves independent of this new state of Bosnia and Herzegovina and declared their own independent state, the Republika Srpska. Subsequently, fighting erupted between the army of Bosnia and Herzegovina, dominated by Bosnian Muslims (Armija Bosna I Herzegovina (hereinafter: ABiH)) and the Bosnian Serb army (supported by the rump state Yugoslavia under the command of S. Milošović) (Bosnian Serb Army (hereinafter: BSA) or Vojska Republijke Srpske (hereinafter: VRS)).

2.5 By Resolution 758 of 8 June 1992, the Security Council extended the UNPROFOR mandate to include Bosnia and Herzegovina.

2.6 Srebrenica is a city situated in eastern Bosnia and Herzegovina (hereinafter: the city of Srebrenica). From 1992, eastern Bosnia and Herzegovina was the scene of fighting, first between Muslim fighters and Serbian militias, later between the AbiH and the VRS. As a result, Muslim enclaves developed. The enclave 'Srebrenica' was one of them. This enclave, which was controlled by the Muslim fighters and later by the $\mathrm{ABiH}$, consisted of an area of almost 900 square kilometres around the city of Srebrenica in January 1993. After fights with the Bosnian Serbs, this area was reduced to approximately 150 square kilometres around the city of Srebrenica in March 1993.

2.7 In early 1993, Srebrenica was surrounded and became isolated. Relief convoys sent by the United Nations High Commissioner for Refugees (hereinafter: UNHCR) were stopped by the VRS. Helicopters were fired at by the VRS. A humanitarian crisis developed with lack of water, food, electricity and medication.

2.8 Under the circumstances, the then Commander of UNPROFOR, the (French) general Ph.P.L.A. Morillon (hereinafter: Morillon), accompanied by officials from Médecins Sans Frontières (hereinafter: MSF), visited the besieged and overpopulated Srebrenica on 10 March 1993. On 14 March 1993, he addressed a crowd of Bosnian Muslims, promising them that they were under UN protection and that he would not forsake them.

2.9 On 16 April 1993 the Security Council adopted Resolution 819, which included:

"1. Demands that all parties and others concerned treat Srebrenica and its surroundings as a safe area which should be free from any armed attack or any other hostile act;

2. Demands also to that effect the immediate cessation of armed attacks by Bosnian Serb paramilitary units against Srebrenica and their immediate withdrawal from the areas surrounding Srebrenica; 
3. Demands that the Federal Republic of Yugoslavia (Serbia and Montenegro) immediately cease the supply of military arms, equipment and services to the Bosnian Serb paramilitary units in the Republic of Bosnia and Herzegovina;

4. Requests the Secretary-General, with a view to monitoring the humanitarian situation in the safe area, to take immediate steps to increase the presence of UNPROFOR in Srebrenica and its surroundings; demands that all parties and others concerned cooperate fully and promptly with UNPROFOR towards that end; and requests the Secretary-General to report urgently thereon to the Security Council;

5. Reaffirms that any taking or acquisition of territory by the threat or use of force, including through the practice of "ethnic cleansing", is unlawful and unacceptable;

6. Condemns and rejects the deliberate actions of the Bosnian Serb Party to force the evacuation of the civilian population from Srebrenica and its surrounding areas as well as from other parts of the Republic of Bosnia and Herzegovina as part of its overall abhorrent campaign of "ethnic cleansing";

(...)

8. Demands the unimpeded delivery of humanitarian assistance to all parts of the Republic of Bosnia and Herzegovina, in particular to the civilian population of Srebrenica and its surrounding areas and recalls that such impediments to the delivery of humanitarian assistance constitute a serious violation of international humanitarian law;

(...)

10. Further demands that all parties guarantee the safety and full freedom of movement of UNPROFOR and of all other United Nations personnel as well as members of humanitarian organizations;

11. Further requests the Secretary-General, in consultation with UNHCR and UNPROFOR, to arrange for the safe transfer of the wounded and ill civilians from Srebrenica and its surrounding areas and to urgently report thereon to the Council;

(...)"

2.10 On 18 April 1993, VRS general R. Mladić (hereinafter: Mladić) and AbiH general S. Halilovic (hereinafter: Halilovic), in the presence of the commander of UNPROFOR, concluded a demilitarisation agreement under which all arms in the city of Srebrenica should be handed over to UNPROFOR. On 8 May 1993, they entered into a supplementary demilitarisation agreement pursuant to which the zone to be demilitarised was extended to include the entire enclave of Srebrenica and it surrounding areas. Subsequently, the Bosnian Serbs were to withdraw their heavy weapons which constituted a threat to the demilitarised zones. These agreements will be referred to hereinafter as the demilitarisation agreements.

2.11 On 6 May 1993, the Security Council adopted Resolution 824, which extended the regime of Resolution 819 to five other enclaves within Bosnia and Herzegovina.

2.12 On 15 May 1993, the UN and Bosnia and Herzegovina signed the Agreement on the status of the United Nations Protection Force in Bosnia and Herzegovina (also known as the Status of Forces Agreement, hereinafter: SOFA), which set out the (legal) status of UNPROFOR in Bosnia and Herzegovina. 
2.13 By Resolution 836 of 4 June 1993 the Security Council decided, inter alia:

"Reaffirming in particular its resolutions 819 (...) and 824 (...)

Reaffirming the sovereignty, territorial integrity and political independence of the Republic of Bosnia and Herzegovina and the responsibility of the Security Council in this regard,

Condemning military attacks, and actions that do not respect the sovereignty, territorial integrity and political independence of the Republic of Bosnia and Herzegovina (...)

(...)

Reaffirming once again that any taking of territory by force or any practice of "ethnic cleansing" is unlawful and totally unacceptable,

(...)

Deeply concerned by the continuing armed hostilities in the territory of the Republic of Bosnia and Herzegovina which run totally counter to the Peace Plan, (...)

Determined to ensure the protection of the civilian population in safe areas and to promote a lasting political solution,

(...)

Determining that the situation in the Republic of Bosnia and Herzegovina continues to be a threat to international peace and security,

(...)

3. Reaffirms the unacceptability of the acquisition of territory by the use of force and the need to restore the full sovereignty, territorial integrity and political independence of the Republic of Bosnia and Herzegovina;

4. Decides to ensure full respect for the safe areas referred to in resolution 824 (1993);

5. Decides to extend to that end the mandate of UNPROFOR in order to enable it, in the safe areas referred to in resolution 824 (1993), to deter attacks against the safe areas, to monitor the cease-fire, to promote the withdrawal of paramilitary units other than those of the Government of the Republic of Bosnia and Herzegovina and to occupy some key points on the ground, in addition to participating in the delivery of humanitarian relief to the population as provided for in resolution 776 (1992) of 14 September 1992;

6. Affirms that these safe areas are a temporary measure and that the primary objective remains to reverse the consequences of the use of force and to allow all persons displaced from their homes in the Republic of Bosnia and Herzegovina to return to their homes in peace, beginning, inter alia, with the prompt implementation of the provisions of the Vance-Owen Plan [Court of Appeal: the Peace Plan of January 1993] in areas where those have been agreed by the parties directly concerned;

7. Requests the Secretary-General, in consultation, inter alia, with the Governments of the Member States contributing forces to UNPROFOR:

(a) To make the adjustments or reinforcement of UNPROFOR which might be required by the implementation of the present resolution, and to consider assigning UNPROFOR elements in support of the elements entrusted with protection of safe areas, with the agreement of the Governments contributing forces; 
(b) To direct the UNPROFOR Force Commander to redeploy to the extent possible the forces under his command in the Republic of Bosnia and Herzegovina;

8. Calls upon Member States to contribute forces, including logistic support, to facilitate the implementation of the provisions regarding the safe areas, (...) and invites the Secretary-General to seek additional contingents from other Member States;

9. Authorizes UNPROFOR, in addition to the mandate defined in resolutions 770 (1992) of 13 August 1992 and 776 (1992), in carrying out the mandate defined in paragraph 5 above, acting in self-defence, to take the necessary measures, including the use of force, in reply to bombardments against the safe areas by any of the parties or to armed incursion into them or in the event of any deliberate obstruction in or around those areas to the freedom of movement of UNPROFOR or of protected humanitarian convoys;

10. Decides that, notwithstanding paragraph 1 of resolution 816 (1993), Member States, acting nationally or through regional organizations or arrangements, may take, under the authority of the Security Council and subject to close coordination with the Secretary-General and UNPROFOR, all necessary measures, through the use of air power, in and around the safe areas in the Republic of Bosnia and Herzegovina, to support UNPROFOR in the performance of its mandate set out in paragraphs 5 and 9 above;

(...)"

2.14 In his report of 14 June 1993, the UN Secretary-General analysed the modalities in which Resolution 836 could be implemented, which included, inter alia:

"5. A military analysis by UNPROFOR has produced a number of options for the implementation of resolution 836 (1993), with corresponding force levels. In order to ensure full respect for the safe areas, the Force Commander of UNPROFOR estimated an additional troop requirement at an indicative level of approximately 34,000 to obtain deterrence through strength. However, it would be possible to start implementing the resolution under a "light option" envisaging a minimal troop reinforcement of around 7,600. While this option cannot, in itself, completely guarantee the defence of the safe areas, it relies on the threat of air action against any belligerents. Its principle advantage is that it presents an approach that is most likely to correspond to the volume of troops and material resources which can realistically be expected from Member States and which meet the imperative need for rapid deployment. (...)

6. This option therefore represents an initial approach and has limited objectives. It assumes the consent and cooperation of the parties and provides a basic level of deterrence, with no increase in the current levels of protection provided to convoys of the Office of the United Nations High Commissioner for Refugees (UNHCR). It does however maintain provision for the use of close air support for self-defence and has a supplementary deterrent to attacks on the safe areas. (...)"

2.15 The term "close air support" in the abovementioned report refers to the deployment of air power in direct support of the UN ground forces. "Close air support" is not to be confused with the term "air strikes", which refers to an air attack of a destructive nature. The application procedure for close air support 
consisted of two parts: 1. approval by the UN, by, successively, the sector headquarters in Tuzla, UNPROFOR in Sarajevo, the UNPF headquarters in Zagreb, the Crisis Action Team under the command of the chief-of-staff in Zagreb, the Force Commander (Janvier) and the UN Special Envoy for Bosnia and Herzegovina (Akashi), as well as 2. approval by NATO, more particularly by the Commander-inChief Allied Forces Southern Europe in Naples, after involvement of the liaison officers in Sarajevo or Zagreb and the Combined Air Operation Center (CAOC) of the NATO airbase in Vicenza.

2.16 The Security Council adopted the option referred to as the 'light option' in the above report in its Resolution 844 of 18 June 1993.

2.17 On 3 September 1993, the Dutch Permanent Representative to the UN offered to the UN Secretary-General military advisor a battalion of the Airmobile Brigade (hereinafter: Dutchbat) for the implementation of Resolution 836 in the safe areas referred to therein (term used in paragraph 1 of Resolution 819, see 2.9 above). On 7 September 1993, the Dutch Minister of Defence repeated this offer to the UN Secretary-General, who accepted it on 21 October 1993. On 12 November 1993, the Dutch Government approved the deployment of Dutchbat.

2.18 On 3 March 1994, Dutchbat relieved the Canadian regiment present in the Srebrenica enclave. In July 1994, Dutchbat I was relieved by Dutchbat II, which was relieved by Dutchbat III in January 1995.

2.19 Dutchbat headquarters was set up in an abandoned factory at Potočari (hereinafter: the compound). The compound was situated in the safe area, at approximately five kilometres from the city of Srebrenica. One Dutchbat company was stationed inside the city of Srebrenica. Besides, Dutchbat manned a number of observation posts (hereinafter also: OPs or Ops).

2.20 Dutchbat was placed under the command of the UN and functioned as an UNPROFOR contingent. The State had handed over command and control to the UN to carry out the mandate in $\$ 5$ and $\$ 9$ of Resolution 836 (see 2.13 above). The command and control handed over to the UN by the State is described, inter alia, in the operation order of 14 December 1994 at the relief of Dutchbat II by Dutchbat III. The operation order reads, inter alia:

\section{“a. Command}

(...)

Upon arrival in $Y U$ [Court of Appeal: Yugoslavia] Dutchbat is uoc [NATO: operational controll (opcon)] of UNPROFOR".

Note 1 to operational control reads:

"OPCON. The authority delegated to a commander to direct forces assigned so that the commander may accomplish specific missions or tasks which are usually limited by function, time or location; to deploy units concerned, and to retain or assign tactical control of those units. It does not include authority to assign separate employment of components of the units concerned. Neither does it, of itself, include administrative or logistic control [NL: onder operationeel bevel (oob- under operational control)]"

2.21 The command and control handed over to the UN by the State included control over the operational implementation of the mandate by Dutchbat. In this respect, Dutchbat was controlled via the UN chain of command of UNPROFOR, 
which issued operational orders and instructions to the Dutchbat Commander. The State retained the authority to call back troops, discontinue participation in the operation, and to discipline soldiers, and retained control over the preparation of the Dutch troops, personnel matters and material logistics.

2.22 Dutchbat was bound by the codes of conduct and instructions established by the UN chain of command: the Rules of Engagement, the Standing Operating Procedures (hereinafter: SOP), and the Policy Directives drafted by the Force Commander. The Ministry of Defence laid down these codes of conduct and instructions, plus a number of existing rules and rules especially drafted for this mission, in (Dutch) Standing Order 1 (NL) UN Infbat.

2.23 In the period relevant to this case and in so far as significant here, the following individuals held the following positions:

Within the UN hierarchy:

UN:

i) the UN Secretary-General was Boutros Boutros-Ghali (hereinafter: the UN Secretary-General);

ii) the Special Envoy to the UN for Bosnia and Herzegovina was Yasushi Akashi (hereinafter: Akashi);

UNPROFOR in Zagreb (Croatia) (from 1 April 1995 UNPF):

iii) the Force Commander was (French) Lieutenant General B. Janvier (hereinafter: Janvier);

iv) the Chief of Staff was (Dutch) Brigadier General A.M.W.W.M. Kolsteren (hereinafter: Kolsteren);

v) the Chief of Operations was (Dutch) Colonel J.H. de Jonge (hereinafter: De Jonge);

BOSNIA AND HERZEGOVINA COMMAND UNPROFOR in Sarajevo (Bosnia and Herzegovina) (from May 1995 HQ UNPROFOR):

vi) the Commander was (British) Lieutenant General Sir R.A. Smith (hereinafter: Smith);

vii) the Deputy Commander was (French) General H. Gobilliard (hereinafter: Gobilliard);

viii) the Chief of Staff was (Dutch) Brigadier General C.H. Nicolai (hereinafter: Nicolai);

ix) Assistant Chief of Staff was (Dutch) Lieutenant Colonel J.A.C. de Ruiter (hereinafter: De Ruiter);

Sector North East in Tuzla (unit of HQ UNPROFOR):

$\mathrm{x}$ ) the Commander was (Norwegian) Brigadier General H. Haukland;

xi) the Chief of Staff and Deputy Commander was (Dutch) Colonel C.L. Brantz (hereinafter: Brantz);

\section{Dutchbat III in Srebrenica:}

xii) the Battalion Commander was (Dutch) Lieutenant Colonel Th.J.P Karremans (hereinafter: Karremans);

xiii) the Deputy Battalion Commander was (Dutch) Major R.A. Franken (hereinafter: Franken).

Also appearing in the documents are the names of (Dutch) Captain J.R. Groen (hereinafter: Groen) and (Dutch) Second Lieutenant J.H.A. Rutten (hereinafter: 
Rutten). Groen was Commander of B Company. Rutten was Patrol Coordinator of C Company and intelligence officer.

Non-UN positions were as follows:

\section{In the Netherlands:}

xiv) the Minister of Defence was J.J.C. Voorhoeve (hereinafter: Voorhoeve);

xv) Chief of the Defence Staff was Lieutenant General H.G.B. van den Breemen (hereinafter: Van den Breemen);

xvi) Deputy Commander of the Royal Netherlands Army (hereinafter: RNLA) was Major General A.P.P.M. Van Baal (hereinafter: Van Baal).

The Defence Crisis Control Centre (DCCC) monitored from The Hague what happened during the peacekeeping operation from a policy perspective.

xvii) the Deputy Chief of Defence Staff (Operations) at the DCCC was Commodore C.G.J. Hilderink (hereinafter: Hilderink).

On behalf of NATO a NATO officer was present in Zagreb to liaise with the Commander-in-Chief Allied Forces Southern Europe headquarters in Naples (hereinafter: CINCSOUTH), namely American Admiral Leighton Smith (hereinafter: Admiral Smith or Leighton Smith, not to be confused with the Smith placed at the disposal of the UN referred to under (vi) above).

2.24 The supply of goods to the safe area went by convoy through largely Bosnian Serb territory. From mid 1994, the Bosnian Serbs refused passage to convoys on their way to the safe area, as a result of which not all humanitarian aid and food intended for the population in the safe area reached its destination. The provisioning of Dutchbat suffered from this, too.

2.25 On 25 and 26 May 1995, NATO carried out air attacks (air strikes) on targets close to the Bosnian Serb government quarter in Pale. Next, the Bosnian Serbs took hundreds of UNPROFOR soldiers captive to use them as hostages in order to ward off further attacks. On 28 May 1995, the Bosnian Serbs occupied two Britbat observation posts and took the British soldiers hostage, after which Britbat retreated to its compound. Pending further orders from Smith, Nicolai and Karremans decided upon consultation that preparations should be made to abandon the observation posts within the hour if necessary. The observation posts would be maintained until further notice or until they were under serious threat, subject to instructions by Nicolai that no unnecessary risk should be run.

2.26 After the said air strikes, UNHCR convoys only sporadically succeeded in reaching Srebrenica, as a result of which the UN could only provide $30 \%$ of the food needs in June 1995 (NIOD report p. 1912).

2.27 On 29 May 1995, Smith issued a Post Airstrike Guidance, which read, in so far as relevant here:

“7. I have been directed, today 29 May 95, that the execution of the mandate is secondary to the security of UN personnel. The intention being to avoid loss of life defending positions for their own sake and unnecessary vulnerability to hostage taking. My interpretation of this directive is at paragraph 9b".

Paragraph $9 \mathrm{~b}$ reads as follows, in so far as relevant here:

"Positions that can be reinforced, or it is practical to counter attack to recover, are not to be abandoned. Positions that are isolated in BSA territory and unable to 
be supported may be abandoned at the Superior Commanders discretion when they are threatened and in his judgment life or lives have or will be lost. (...)."

2.28 On 3 June 1995, shootings occurred at OP-E, and OP-E was surrounded by Bosnian Serbs. Dutchbat then requested close air support. The request was denied. Dutchbat then abandoned this observation post in a YPR (a light tracked armoured vehicle), while being shot at by the Bosnian Serbs. Dutchbat did not set fire to OP-E as was a standing order in the event of forced abandonment of an OP (NIOD report p. 2005).

2.29 On 6 July 1995, the Bosnian Serbs launched an attack on the safe area under the command of Mladić. When the Bosnian Serbs approached the city of Srebrenica, the objective of this attack was extended to occupying the city of Srebrenica.

2.30 During this attack on the safe area the $\mathrm{ABiH}$ asked Dutchbat repeatedly to be given (back) the arms handed in under the demilitarisation agreements. Dutchbat denied these requests.

2.31 On 6 July 1995, fighting also occurred at observation post OP-F between the Bosnian Serbs and ABiH (NIOD report p. 2100). In the process, observation post OP-F was hit by shells fired from Bosnian Serb tanks twice. That day, the Bosnian Serbs also shelled the city of Srebrenica. A request for close air support by Dutchbat that same day was denied.

2.32 On 8 and 9 July 1995, Dutchbat abandoned the observation posts OP-F, OPU, OP-S, OP-K, OP-D and (upon retreat) OP-M. When retreating, Dutchbat soldiers did not fire at the Bosnian Serbs. They allowed Bosnian Serbs to disarm them, handed over armoured vehicles and taught them how to drive them. Also, Dutchbat soldiers departed with the Serbs; they were taken prisoner.

2.33 In the morning of 9 July 1995, airplanes appeared above the safe area on the request of HQ UNPROFOR ('air presence'). UNPROFOR Zagreb did not take a decision on a request for close air support made later that day.

2.34 In the evening of 9 July 1995, Dutchbat received verbal instructions to take up so-called blocking positions to put up a barrier against the advance of the Bosnian Serbs. The order confirming the verbal instructions, drawn up in the Dutch language by De Ruiter and signed by Nicolai, reads as follows:

"With the means available you must take up such "blocking positions" that further breakthrough and advance of VRS units towards the city of Srebrenica are prevented. You must do everything possible to reinforce these positions, also in respect of arming them. These blocking positions must be recognisable on the ground. You can expect the supplementary means promised as from Monday, 10 July 1995."

The VRS was informed that if it attacked a blocking position, close air support would be deployed (NIOD report p. 2151).

2.35 In the early morning of Monday, 10 July 1995, Dutchbat took up four blocking positions (Bravo 1-4); Bravo-1 west of the city of Srebrenica, Bravo-2 and 4 on the road from Zeleni Jadar to Srebrenica and Bravo-3 east of Srebrenica. As the position of Bravo-2 was within range of Bravo-4, in actual practice Bravo-2 was not used. At 7:13 p.m. Groen ordered the Bravo-1 crew to retreat to Srebrenica. The crews manning Bravo-3 and 4 also retreated. No close air support was given that 
day. In the night of 10 to 11 July 1995, the soldiers manning Bravo-1, 3 and 4 stayed in the city of Srebrenica.

2.36 On 10 July 1995, Voorhoeve said in current affairs programme NOVA on Dutch television:

"In the next few weeks we have to give topmost priority to the safety of Dutch military personnel. The commanders are instructed to avoid victims first and foremost. I want to see all men and women return home safely. (...) We have spoken to all those commanders, by telephone and otherwise in the past few days. We do not want Dutch personnel to be at risk, to hold untenable positions. Be sensible and bring all our boys and girls home safe and sound." The said instruction to Dutchbat to prevent victims is also known as 'the Voorhoeve instruction'.

2.37 In the early evening of 10 July 1995, Karremans and Franken decided to admit refugees to the compound in numbers that would fit into the large vehicle halls within the compound. That evening a hole was made in the fence in the southwestern corner of the compound for that purpose. No refugees entered the compound that evening.

2.38 On Tuesday, 11 July 1995 at around 8:00 a.m., Dutchbat requested close air support. The request was denied. A subsequent request for close air support, made around 10:00 a.m., was approved by the UN around noon and approximately half an hour later by NATO. Bombs were dropped around 2:45 p.m. Around 3:30 p.m. new airplanes took off. They did not drop bombs. Close air support was discontinued.

2.39 On 11 July 1995 Groen ordered Bravo- 1 to abandon its position and retreat from Srebrenica towards Potočari together with the Bravo-3 and 4 crew. Franken then ordered Groen to take up a new blocking position at the junction to Susnjari, south of the compound. Dutchbat did so around 4 p.m. Under threat of VRS units this blocking position was abandoned a few hours later and disarmed by Bosnian Serbs.

2.40 On 11 July 1995 around 4:30 p.m., the city of Srebrenica fell and was occupied by Bosnian Serbs.

2.41 Earlier that afternoon, at around 2:30 p.m., a stream of Bosnian Muslim refugees had started to move from the city of Srebrenica to the compound.

In the course of the afternoon of 11 July 1995, refugees were admitted to the compound through the hole in the fence until the vehicle halls were full. At 4:30 p.m. the gates to one of the factory sites near the compound were opened. At that point, the hole in the fence had already been closed.

2.42 After the fall of Srebrenica a mini safe area was set up, consisting of the compound in Potočari and a nearby area to the south which housed halls and a coach depot. The area was cordoned off with tape and the access roads with armoured vehicles. Control posts were set up at the edges. Maybe as many as 30,000, but at least approximately 20,000 to 25,000 refugees sought refuge in the mini safe area. About 5,000 of them were put up in the vehicle halls in the compound.

2.43 Approximately 10,000 to 15,000 men from the safe area did not flee to the mini safe area, but instead fled to the woods surrounding the city of Srebrenica (hereinafter: the woods). Around 6,000 of these men fell into Bosnian Serb hands.

2.44 Circumstances in the mini safe area were poor. There was little food, not enough water for all refugees, a shortage of medical resources and lack of hygiene. 
Temperatures rose to $35{ }^{\circ} \mathrm{C}$ in that period. Circumstances deteriorated visibly on 12 and 13 July 1995.

2.45 On 11 July 1995 at 6.45 p.m. Karremans received a fax from Gobilliard with the following contents (hereinafter also: Gobilliard's order):

"a. Enter into local negotiations with BSA forces for immediate cease-fire. Giving up any weapons and military equipment is not authorised and is not a point of discussion.

b. Concentrate your forces into the Potočari Camp, including withdrawal of your Ops. Take all reasonable measures to protect refugees and civilians in your care.

c. Provide medical assistance and assist local medical authorities.

$d$. Continue with all possible means to defend your forces and installation from attack. This is to include the use of close air support if necessary.

$e$. Be prepared to receive and coordinate delivery of medical and other relief supplies to refugees."

2.46 In the evening of 11 July 1995, Janvier, Van den Breemen and Van Baal spoke in Zagreb about the situation that had arisen after the fall of Srebrenica.

2.47 In the evening of 11 July 1995, Karremans spoke with Mladic about the evacuation of refugees from the mini safe area twice, and in the morning of 12 July 1995 a third time. Mladic then mentioned the order in which the refugees would be transported. Mladić informed Karremans that males between the ages of 17 and 60 would first be screened for war crimes (inter alia, NIOD report p. 2641). After it had initially been agreed that Dutchbat would supervise the evacuation and arrange transport for the refugees, in his last conversation with Karremans Mladić disclosed that he himself would take care of their transport.

2.48 On 12 July 1995, the Security Council adopted Resolution 1004 'Demanding withdrawal of the Bosnian Serb forces from the safe area of Srebrenica, Bosnia and Herzegovina' (hereinafter: UN Resolution 1004), which included, inter alia, the following:

"1. Demands that the Bosnian Serb forces cease their offensive and withdraw from the safe area of Srebrenica immediately; (...)

(...)

6. Requests the Secretary-General to use all resources available to him to restore the status as defined by the Agreement of 18 April 1993 of the safe area of Srebrenica in accordance with the mandate of UNPROFOR, and calls on the parties to cooperate to that end."

This Resolution was not complied with. The Bosnian Serbs did not heed the call to cease their offensive and withdraw from the safe area immediately, nor did the Resolution result in an order to Dutchbat to take in positions in and around Srebrenica or otherwise attempt to recapture Srebrenica by military intervention.

2.49 In the early afternoon of 12 July 1995, on the orders of the Bosnian Serbs, buses and trucks (hereinafter always jointly: buses) arrived at the mini safe area. At around 2 p.m., the evacuation of the refugees from the mini safe area started. A massive run on the buses ensued, and there was a threat of refugees trampling each other. The first buses were overcrowded.

2.50 In consultation with the Bosnian Serbs, Dutchbat then supervised the movement to the buses by creating a kind of corridor of vehicles and a human 
cordon of Dutchbat soldiers and tape. The refugees, called out in numbers by the Dutchbat soldiers, passed through this 'corridor' to the buses (see also NIOD report p. 2649). The buses then transported the refugees to Tišca, from where, after marching for kilometres to Kladanj and a bus ride arranged by the UN, they reached a provisional shelter at Tuzla airport (inter alia, NIOD report p. 2651).

2.51 The Bosnian Serbs took male refugees from the rows of refugees on their way to the buses. In the afternoon of 12 July 1995, the Bosnian Serbs started to transport these male refugees in separate buses.

2.52 In the evening of 12 July 1995, the evacuation of refugees stopped. By that time, 4,000 to 5,000 refugees had been evacuated.

2.53 On 12 and 15 July 1995, Dutchbat abandoned the remaining observation posts (OP-A, OP-C, OP-N, OP-P, OP-Q, and OP-R). On 12 July 1995 around 10 p.m., the Bosnian Serbs dropped off the crew of observation post OP-P at the compound. The crew of observation post OP-C was escorted to Milici by the Bosnian Serbs. The crews of the other observation posts were taken to Bratunac by the Bosnian Serbs.

2.54 Various Dutchbat soldiers observed war crimes committed by Bosnian Serbs between 10 and 13 July 1995.

2.55 Dutchbat did not report the war crimes observed by its soldiers within the UN chain of command immediately. Karremans orally informed the Bosnia and Herzegovina Command in Sarajevo of the find of nine bodies by Rutten on Thursday morning 13 July 1995, and also brought this to Nicolai's attention. Furthermore, Karremans claims to have orally reported within the UN chain of command the observation by a Dutchbat soldier of the execution of a refugee, but this report has not been established for a fact. Dutchbat did not report any other war crimes until after the evacuation.

2.56 In the night of 12 to 13 July 1995, Bosnian Serbs raped female refugees.

2.57 On 13 July 1995, Franken had a list made of male refugees aged between 15 and 60 who were in the compound (hereinafter: "Franken's list"), which list contained 251 names. He faxed the list to various national and international authorities and told this to the Bosnian Serbs. About 70 men in the compound refused to have their names taken down on the list for fear of trouble instead of protection.

2.58 On 13 July 1995, the evacuation was resumed. When the buses appeared in the morning before the Bosnian Serbs did, Dutchbat just started to escort the refugees, including the men, to the buses. A number of these buses left before the Bosnian Serbs arrived over an hour later. En route, the Bosnian Serbs stopped part of these buses and removed the men from them.

$2.59 \mathrm{By}$ the end of the afternoon of 13 July 1995 all refugees in the part of the mini safe area situated outside the compound had been moved out, and a start was made with moving out the refugees staying within the compound. In the evening of 13 July 1995, according to the International Criminal Tribunal for the former Yugoslavia (hereinafter: ICTY) at 8 p.m., the evacuation of these refugees was finished.

2.60 After the fall of Srebrenica, genocide was committed against Bosnian Muslims. As has been established later, buses with male refugees went from 
Potočari to Bratunac. The men who had not gone to the mini safe area but had fled to the woods and had been taken captive, were also taken to Bratunac. In total, the Bosnian Serbs killed approximately 7,000 male Bosnian Muslims from the safe area in a number of different locations in mass executions, which started on 13 July 1995 in the area north of the city of Srebrenica and subsequently took place from 14 through 17 July 1995 in several places north of Bratunac. Moreover, the Bosnian Serbs killed between 100 and 400 Bosnian Muslim men in Potočari on 12 and 13 July 1995.

2.61 Dutchbat abandoned the compound on 21 July 1995.

Facts found in respect of parties to the action 1 through 11 (the Association et al.)

3.1 Before the war, Mrs [appellant 1] lived with he husband and her son in the city of Srebrenica. On 11 July 1995, her husband fled to the woods. He was never found back. Mrs [appellant 1] and her son sought refuge in the part of the mini safe area situated outside the compound. Her son was separated from her on 13 July 1995. She has not seen him since.

3.2 Before the war, Mrs [appellant 2] lived in [place of residency], near Potočari. Her husband and two sons fled into the woods. Remains of her husband's body were found in a mass grave in 2005. The bodies of her sons have not been found to date. On 11 July 1995, she sought refuge in the part of the mini safe area situated outside the compound.

3.3 Before and during the war, Mrs [appellant 3] lived in Potočari. On 11 July 1995, her husband and two sons fled into the woods. She and her daughter fled to the mini safe area, but were not admitted to the compound. She lost her husband and sons.

3.4 In 1992, Mrs [appellant 4] fled with her husband and children to the city of Srebrenica. On 11 July 1995, two of her sons fled into the woods. She has not seen them alive since. Mrs [appellant 4] fled with her husband to the part of the mini safe area situated outside the compound. On 13 July 1995, she was separated from her husband, whom she has not seen since. The body of one of her sons was identified in 2003.

3.5 From the start of the war, Mrs [appellant 5] lived with he husband and her son in the city of Srebrenica. Her son fled into the woods on 11 July 1995. Mrs [appellant 5], her husband and her brother fled to the mini safe area. They were not admitted to the compound. On 12 July 1995, her brother was taken for questioning by the Bosnian Serbs. He never returned. On 13 July 1995, she was separated from her husband. Her husband's body was found in a mass grave. She does not know anything about her son's fate.

3.6 During the war, Mrs [appellant 6] lived with her family in the city of Srebrenica. Her husband was taken captive as a prisoner of war by the Bosnian Serbs in 1993, and has been missing since. On 11 July 1995 Mrs [appellant 6] fled to the mini safe area. On their way there her two sons fled into the woods. Mrs [appellant 6] did not try to get into the compound because she had heard that no more refugees were admitted. The mortal remains of her elder son have been found since. She never saw her other son again. 
3.7 Before and during the war, Mrs [appellant 7] lived with her husband and son in [place of residency], close to the compound. Her husband fled to Tuzla before the fall of Srebrenica. Her son fled into the woods on 11 July 1995. His body has been found since. Mrs [appellant 7] fled to the mini safe area and was admitted to the compound.

3.8 From the start of the war, Mrs [appellant 8] lived in the city of Srebrenica. On 11 July 1995, Mrs [appellant 8] and her husband fled to the mini safe area, where she was told nobody could get into the compound anymore. On 13 July 1995 she was separated from her husband. She has never seen him since.

3.9 During the war, Mrs [appellant 9] lived with he husband and two sons in the city of Srebrenica. One son fled at the beginning of the war and survived. During the fall of Srebrenica Mrs [appellant 9] fled with her husband and her other son [name] to the mini safe area. [Name] was admitted to the compound, she and her husband were not. On 12 July 1995, her son [name] was moved from the compound. He has not been found to date. On 13 July 1995, [appellant 9] was separated from her husband when they tried to get to the buses. The mortal remains of her husband were found in 2004.

3.10 In 1993, Mrs [appellant 10] moved to the city of Srebrenica with her parents and sister. Her father fled into the woods on 11 July 1995. Later, his body was found in a mass grave. Mrs [appellant 10] fled with her mother and sister to the mini safe area. They were not admitted to the compound and sought refuge in the part of the mini safe area situated outside the compound. Mrs [appellant 10]'s mother was raped by the Bosnian Serbs and died in 1996.

3.11 The Association has full legal personality under Netherlands law, and its object is - stated succinctly - promoting the interests of (approximately 6,000) surviving relatives of victims of the fall of Srebrenica. It is authorised under Article 3:305a of the Dutch Civil Code ('DCC') to institute the disputed claims, except to claim (an advance payment of) damages.

\section{Claim, basis and defence}

In both cases:

4.1 On 4 June 2007, the Association et al. summoned both the State and the United Nations before the District Court in The Hague, claiming - concisely summarised - that the court, with immediate effect:

I. rules that the State and the United Nations failed imputably in the performance of the obligation vested in Dutchbat towards the women referred to in 1 through 10 as well as the surviving relatives whose interests the Association promotes of protecting the population of the so-called safe area against the Bosnians Serbs;

II. rules that the State and the United Nations acted wrongfully to the women referred to in 1 through 10 as well as the surviving relatives whose interests the Association promotes;

III. rules that the State and the United Nations violated their duty to prevent genocide, as defined in the Convention on the Prevention and Punishment of the Crime of Genocide signed on 9 December 1948 (hereinafter: the Genocide Convention);

IV. orders the State and the United Nations to pay damages to the women referred to in 1 through 10 for the loss and suffering sustained, to be assessed and 
settled in accordance with the law, making an advance payment for such damages in the amount of $€ 25,000$ per person;

V. orders the State and the United Nations to pay the costs of the proceedings.

4.2 The Association et al. have based their claims, stated very succinctly, on the fact that genocide was committed in the eastern Bosnian enclave of Srebrenica in July 1995, and that the women referred to in 1 through 10 and the persons whose interests the Association promotes are surviving relatives of the men and boys who were murdered on that occasion by the Bosnian Serbs. The UN and the State are liable for the loss suffered by them as a consequence because

1. the UN and the State, contrary to undertakings given, failed imputably in the performance of the duty to protect the population in the mini safe area, which duty arose from the agreement between the State and the UN to provide troops for the protection of that population and is deemed a third-party clause within the meaning of Article 6:253 DCC, and

2. they acted wrongfully towards the Association et al. under national and international (humanitarian) law -including the European Convention on Human Rights (hereinafter: ECHR), the International Covenant on Civil and Political Rights (hereinafter: ICCPR), the Geneva Conventions, the UN Charter, the SOP, and the mandate, and

3. they breached the obligation to prevent genocide.

4.3 By judgment of 10 July 2008, the District Court declared it had no jurisdiction to hear the action in so far as it was directed against the UN. After appeal to this Court of Appeal, appeal to the Supreme Court and a complaint to the European Court of Human Rights (hereinafter: ECtHR) this decision was upheld (Supreme Court 13 April 2012, ECLI:NL:HR:2012:BW1999 and ECtHR 11 June 2013, case no. 65542/12).

4.4 The proceedings were then continued between the Association et al. and the State. The Association et al. maintained their claims against the State before the District Court. They blaim the State for the following:

i. Dutchbat did too little in the period before the fall of Srebrenica to ensure that convoys with food and humanitarian aid reached the safe area;

ii. Dutchbat did too little in the period before the fall of Srebrenica to stop the advance of the Bosnian Serbs and protect the population of the safe area against them, more particularly, Dutchbat:

a) did not put to use the knowledge they had about the intended attack of the Bosnian Serbs;

b) stood by the demilitarisation agreements and refused to return the arms seized when the Bosnian Serbs approached the city of Srebrenica;

c) impeded active resistance by the $\mathrm{AbiH}$;

d) abandoned observation posts;

e) surrendered the blocking positions too readily and too quickly;

iii the State first blocked and later stopped close air support to Dutchbat;

iv the State turned down the French offer of 10 July 1995 to provide Tigre helicopters and crew, and thwarted plans to recapture Srebrenica after the fall of the city; 
v Dutchbat failed to abandon immediately the observation posts it still manned after the fall of Srebrenica, contrary to Gobilliard's order;

vi Contrary to Gobilliard's order, Dutchbat handed over arms and other equipment to the Bosnian Serbs;

vii Dutchbat advised the male refugees to flee into the woods;

viii Dutchbat did not raise a general alarm about the flight of the male refugees to the woods.

ix Dutchbat did not admit all refugees to the compound;

$\mathrm{x}$ Dutchbat failed to report the war crimes it had observed;

xi Dutchbat failed to provide adequate medical care to the refugees;

xii Dutchbat cooperated in separating the male refugees from the other refugees during the evacuation;

xiii Dutchbat cooperated in the evacuation of the refugees who had been put up in the compound.

4.5 The State put forward a reasoned defence.

\section{The District Court's judgment}

In both cases:

5.1 By judgment of 16 July 2014, the District Court ruled in the matter referred to above in 4.1 sub II

"that the State is liable on account of wrongful act for the loss suffered by the persons represented by the Association et al. referred to under 4.339, which loss resulted from the assistance rendered by Dutchbat at the deportation of the male refugees who in the afternoon of 13 July 1995 were deported from the compound in Potočari by the Bosnian Serbs and subsequently killed" [underlining added by the Court of Appeal].

With the "persons referred to under 4.339" the District Court referred to the family members of the male refugees who were deported from the compound in the afternoon of 13 July 1995 and subsequently killed. The District Court applied as basic principle that it considered as family members the wives and children of the adult males and the parents of underage males (and that it considered as adult males those who had reached the age of eighteen).

5.2 The District Court dismissed any other claims against the State brought by the Association et al. than those concerning the deportation of the men and boys from the compound on 13 July 1995. The claims referred to above under 4.1 sub I, III, and IV, including the claim for an advance payment of damages, were dismissed, therefore. The District Court ordered the State to pay the costs of the proceedings.

6. The full text of the District Court judgment stating the grounds of the above decisions can be found under ECLI:NL:RBDH:2014:8562, and, in English, under ECLI:NL:RBDHA:2014:8748. The Court of Appeal will simply refer to those sources, and will, where necessary, address the grounds for the decision of the District Court in its discussion of the grounds for appeal.

\section{Assessment of the appeal}

Grounds for appeal in the principal and the cross-appeals, extension of the grounds for the claim and scope of the appeal

7.1 In both cases, both parties brought grounds for appeal against the judgment of the District Court. By statement of appeal the Association et al. also stated they 
wished to increase their claim in the sense that they supported their claim, besides on the grounds given in the initiating summons, also on the grounds given in the body of the statement of appeal. As in both cases the grounds for appeal in the principal appeals are identical to those in the cross-appeals, the Court of Appeal will, for the sake of brevity, refer to them as 'the Association's ground for appeal' or, as the case may be, 'the State's ground for appeal', thereby referring to the ground for appeal in both the principal appeal and the cross-appeal.

7.2 With regard to the claims of the Association et al. referred to above under 4.4 that Dutchbat did too little to ensure that convoys of food and humanitarian aid reached the safe area, that Dutchbat did not put to use the knowledge of the intended attack by the Bosnian Serbs, and that Dutchbat actively thwarted resistance by the AbiH (items i and ii a and c), the District Court ruled that these actions could not be imputed to the State. Against this no grounds for appeal were adduced. Therefore, the Court of Appeal does not take these claims into consideration.

\section{Non-disclosed documents; obligation to furnish facts and onus of proof}

8.1 Ground 1 put forward by the Association et al. relates to the District Court's judgment that non-disclosure by the State of documents not available to the Association et al. provides no general basis to set lower standards for the Association's obligation to furnish facts and higher or other standards for the State's obligation to furnish facts or onus of proof when assessing the case (District Court judgment grounds 4.20 and 4.21). The Association et al. argued that they did not have the Rules of Engagement of UNPROFOR, the documents relating to the consultations within DCCC, the Dutchbat debriefing reports, the daily situation reports, the interviews conducted with (inter alios) Rutten, and the minutes of the Cabinet for 5, 6, 7, and 11 July 1995. As the Association et al. do not have these documents, the Association et al. argue that lower standards should be set to its obligation to furnish facts and its onus of proof, and higher standards to the State's obligation to furnish facts and the risk of non-persuasion. The State contested this, stating reasons.

8.2 The Court of Appeal states first and foremost that in the adjudication of the case it will not take into account the non-disclosed documents that have not been submitted to the court. The State does not rely on (parts of) such documents either, however. The Court of Appeal considers that a great deal of information about the incidents at issue in this case is public, including the reports referred to under 1.3, which also describe the substance of the non-disclosed documents, as well as many interviews that have been submitted to the court. It can be assumed that in general, therefore, there is sufficient evidence available to furnish relevant facts with supporting arguments. The Court of Appeal also finds that in so far as information from confidential documents was disclosed via the NIOD report, witness examinations or media fragments (such as the video still showing the minutes of the council of ministers), this information does not support the claim of the Association et al. that the State keeps silent about certain information, or lies. With regard to the documents relating to the DCCC, the debriefing reports, and the situation reports, the Court of Appeal further refers to the considerations below under 12.9, 12.10, and 12.11; and with regard to the minutes of the council of ministers it refers to the consideration below under 52.5. In so far as it was 
necessary to examine a witness (further), the Association et al. could offer to produce evidence to that effect.

8.3 In view of this, the Court of Appeal sees no reason in the adjudication of the case to set lower standards to the Association's obligation to furnish facts and higher standards to the State's obligation to furnish facts, or to set a higher risk of nonpersuasion for the State. The Court of Appeal will examine the arguments submitted by the Association et al. and by the State (in each case) on their merits, based on that which has been (sufficiently) argued and whether contested or not contested, and on the law.

\section{Third-party clause Article 6:253 DCC}

9.1 Ground 2 put forward by the Association et al. relates to the District Court's judgment that the agreement between the State and the UN to contribute troops to implement Resolution 836 (see 2.17 above) does not create a right for the population of the safe area to claim protection by the State (grounds of the District Court judgment $4.22 \mathrm{ff}$ ). According to the Association et al. this judgment is wrong and unfounded, and the said agreement contains a third-party clause within the meaning of Article 6:253 DCC. They argued that the State failed attributably to the performance of this obligation towards the Association et al. The Association et al. further argued that the population of the safe area was promised protection several times, and that the State also breached those promises. The State put forward a defence, stating reasons.

9.2 The Court of Appeal presumes (in accordance with the arguments of the Association et al. and in line with its judgment on appeal in the cases of Nuhanovic and Mustafić, ECLI:NL:GHSGR:2011:BR0132, under 5.7), that the course of events referred to above under 2.17 implies an agreement as referred to in Article 6:213 DCC between the State and the UN (which the State contested). It is not in dispute between the parties that Dutch law is applicable.

9.3 The existence of a third-party clause within the meaning of Article 6:253 DCC requires, besides acceptance by the third party, that one party to the agreement stipulates a right for the benefit of the third party, and that the other party to the agreement accordingly commits to the third party to grant the third party an independent right of action against this other party. Whether a third-party clause exists is a matter of interpretation of the agreement, whereby all circumstances of the specific case - to be determined according to criteria of reasonableness and fairness - are of decisive importance, including, but not limited to, the meaning that those parties and the third party reasonably attach to its provisions in the given circumstances, and what they could reasonably expect under it (taking into account all specific circumstances of the given case), the wording of the relevant provision in the agreement, the nature of the agreement, and the extent to which it is intended to affect the legal position of third parties.

9.4.1 Prime consideration is that the wording of UN Resolutions 819 and 836 does not explicitly include protection of the population as a duty of UNPROFOR's. The Association et al. pointed out that the Secretary-General, in a report of 9 May 1994, did expressly define protection of the population as an objective of UNPROFOR. According to this report UNPROFOR construes its mission as follows: "To protect the civilian populations of designated Safe Areas against 
armed attacks and other hostile acts, through the presence of its troops and, if necessary, through the application of air power, in accordance with agreed procedures" and "Should UNPROFOR determine that activities in those Safe Areas pose a threat to their populations, then it will act in accordance with its responsibilities, in close cooperation with the NATO." However, from the same report it also follows that this protection depended strictly on the - unspecified presence of troops and through the application of air power. Air power had to be deployed in accordance with the prevalent procedure, which went via several UN headquarters and NATO (not a party to the agreement referred to here) (see 2.15 above).

9.4.2 There is no evidence whatsoever that it was the intention of the UN and the State to create an independent right of action against the State for the benefit of the population of the safe area - an unknown and unforeseeable number of persons. Also important is that the agreement was not to the effect that the State provide (a complete) UNPROFOR, but UNPROFOR reinforcements. Other battalions from other Member States were active within UNPROFOR for the benefit of this same UN mission. By its nature, the agreement is therefore not an agreement creating an independent right of claim for third parties against one of the Member States with respect to the performance of UNPROFOR.

9.4.3 What is more, within the context of the implementation of UN Resolutions a third-party clause, which creates rights for individual members of the population, may well be at odds with the international-law system of imputation and liability for the actions of UN troops during UN missions. It may not reasonably be expected, and cannot be held at this moment, that the State and the UN implicitly agree to such a third-party clause, i.e. without stating this explicitly.

9.5 In view of all circumstances the Court of Appeal concludes that the agreement between the State and the UN to contribute troops does not create a right for the Association et al. to claim protection of the population of the safe area by the State, or to invoke the agreement against the State in another way.

10.1 The Association et al. put forward the specific promise made by General Morillon to the Bosnian Muslims in Srebrenica in March 1993 about their protection (see 2.8 above). This can be of no avail to them in these proceedings, as there is no indication that Morillon said they would be protected by the State of the Netherlands. Morillon was a French General deployed to UNPROFOR by the UN. This was an announcement that they were under the protection of the UN. For this reason alone, this promise to the population cannot be considered as an undertaking enforceable at law against the State.

10.2 The Association et al. further argued that Dutchbat soldiers promised several times that Dutchbat would protect the population. The court of Appeal holds that if this is true, it was done (according to the Association's own assertions) within the framework of carrying out UN activities, such as ensuring the handing in of weapons or not returning them. The Dutchbat soldiers had all been placed at the disposal of the UN and placed under the command of the UN. The Dutchbat soldiers worked in UN uniforms (blue helmets) and under the UN flag. The population could see that the Dutchbat peacekeepers had been placed at the disposal of the UN for the UN mission and that they formed part of it. The promises put forward were no 
undertakings by or on behalf of the State of the Netherlands, therefore. The Association et al.'s offer of proof (statement of appeal under 37) is therefore disregarded as not relevant to the case.

10.3 The conclusion is that no third-party clause exists, nor any promises pursuant to which the Association et al. can invoke an agreement against the State. Therefore, the second ground for appeal is dismissed as unfounded.

\section{Attribution to the State}

Extended attribution to the State in view of UN immunity?

11.1 Ground 3 put forward by the Association et al. is directed against the District Court judgment that for the method of attribution it is not relevant that the UN enjoys immunity (District Court judgment grounds 4.3 and 4.35). The Association et al. argued in this respect that the ECtHR did not dismiss the Association's complaint of violation of Article 6 ECHR (referred to in 4.3 above) as unfounded, but as inadmissible, and that it is wrong to rule that this immunity has no consequences for the assessment of liability by the State. As the ruling was that the right of access to a court of law was not violated on the very ground (inter alia) that the State, contrary to the UN, could not invoke immunity, the Association et al. argued that attribution to the State should occur in the broadest sense possible. The State contested this ground. The Court of Appeal finds as follows.

11.2 The question whether and to what extent acts performed under the UN flag (and for which the UN, under the Convention on the Privileges and Immunities of the United Nations (Treaty Series 1948, no. I 224) is immune from prosecution) should be attributed to the State, is subject to the provisions of written and unwritten (international) law, including, in particular, those drawn up by the International Law Organisation (ILO), laid down in the Draft Articles on Responsibility of International Organisations (hereinafter: DARIO) and the Draft Articles on Responsibility of States for Internationally Wrongful Acts (hereinafter: DARS). The fact that the rules laid down in international law could lead to the circumstance that the victims could not hold liable the UN (on grounds of immunity) and subsequently one of the UN Member States (on grounds of non-attributability) for certain acts and war crimes committed by the Bosnian Serbs, cannot be blamed on the State, and it does not follow that more should be attributed to the Member State than what it is liable for under the prevalent rules. This ground for appeal is unfounded, therefore.

\section{Attribution to the State, effective control (instruction $(s)$ )}

12.1 Not in dispute is that acts performed by Dutchbat can be attributed to the State if the State exercised effective control over those acts. What really matters is the factual control by the State over that particular specific act (or omission), whereby all factual circumstances and the specific context of the case must be considered. Rightfully - and this was not contested - the District Court found that the single fact that within the UN chain of command Dutch military officials had been appointed, that Dutch UNPROFOR officers sometimes interacted directly with Dutchbat, and that communication existed between Dutch UNPROFOR officers and 
the Dutch government and/or the DCCC, does not entail that the State exercised effective control (grounds for District Court judgment 4.44-4.55).

As the command and control over Dutchbat had been transferred to the UN, the UN exercised effective control over Dutchbat, in principle. Whether in one or more specific instances the exceptional situation occurred that the State also exercised effective control over certain aspects of acts performed by Dutchbat is something that the Association et al. must argue stating sufficient grounds and must prove when contested.

12.2 Ground 4 put forward by the Association et al. relates to the District Court findings that the State did not issue instructions to Dutchbat until 9 July 1995, and that those instructions were limited to the blocking positions (grounds for the District Court judgment 4.62-4.65). According to the Association et al., the District Court failed to recognize that the instructions pertained to giving priority to the safety of Dutchbat itself throughout the Dutchbat operation, and that they referred to: surrendering the observation posts without resistance, abandoning the blocking positions, giving up and handing over arms and equipment, and refusing to return to the population weapons that had been seized, refusing to provide the necessary medical aid to the population and using the means available toward that end, and not protecting the population - all this contrary to orders issued by the UN. According to the Association et al., Dutchbat had made UN orders subordinate to the safety of its own Dutchbat personnel since as early as 8 July 1995. The Association et al. point to remarks made by Voorhoeve on 10 July 1995 about 'avoiding victims', 'giving topmost priority to the safety of Dutch military personnel' and 'wanting to see the men and women return home safely' (see 2.36 above). The Association et al. argued that these remarks formed a pattern and were not limited to an instruction issued by the State about the blocking positions.

12.3 The State challenged this ground, and in particular contested that the State exercised effective control by means of an instruction to Dutchbat to avoid unnecessary victims, as the District Court held.

In this respect, the Court of Appeal finds as follows.

12.4 The Court of Appeals holds, as does the State, contrary to the Association et al. and the District Court, that it cannot be established that remarks made by Voorhoeve on 10 July 1995 about 'avoiding victims', 'giving topmost priority to the safety of Dutch military personnel' and 'wanting to see the men and women return home safely' can be considered as the exercise of effective control over specific acts. The procedural documents do not provide a basis for the conclusion that, through these remarks, factual control has been exercised over specific (certain military operations or other specific) acts performed by Dutchbat. The said remarks were of a general nature, and not intended for specific operational (or other) acts, such as abandoning or not abandoning certain observation posts or blocking positions at some point in time, giving up and handing in arms and equipment, or providing medical care, et cetera. The Association et al. recognize this general nature as well, where they argue that the State's instructions were comprehensive, and that it turned out from the acts performed by Dutchbat that Voorhoeve's instruction was not limited to the blocking positions but pertained to all aspects of acts performed by Dutchbat' (statement of appeal nos. 52 and 54). Irrespective of such remarks, the 
factual acts performed by Dutchbat were governed by specific orders issued by the commanders within the UN chain of command, and not by remarks made by the State. There is nothing to indicate that the State issued specific orders, or caused specific orders to be given in the sense that the safety of Dutchbat personnel had to be given priority over any other consideration. It has also been established that before Voorhoeve made the said remarks, a general superior order had been issued explicitly within the UN chain of command (i.e. by Lieutenant-General Smith) on 29 May 1995 to make the execution of the mandate subordinate to the safety of UN military personnel (see 2.27 above). This was an operational choice made by the UN. That the State in its comments endorsed the priority given to safety because it wanted to see the Dutchbat military personnel return home safe and sound, does not entail that the State exercised factual control over specific operational decisions.

12.5 Contrary to the District Court (see District Court judgment ground 4.66), the Court of Appeal does not consider the statements made by Voorhoeve, Van den Breemen, and Franken, as referred to by the District Court, supportive of the conclusion that the State obtained control over operational affairs via an instruction, or otherwise exercised effective control. These statements are strictly to be construed as (put very succinctly): an expression of hope that measures would be taken by the commanders (Voorhoeve before the Parliamentary Committee of Inquiry (hereinafter: PCI interviews), p. 625), the communication to the UN, after an interview with the Minister, that unnecessary victims should be avoided (Van den Breemen, PCI interviews p.735), and knowledge of the Minister's opinion or information received from the Minister that there should not be any Dutch casualties or fatalities (Franken, PCI interviews p. 67; Hilderink, PCI interviews pp. 212 and 216). It may be indicative of the expression of an opinion and (urgent) wishes, but does not imply instructions or (other) factual control over specific acts. This remains unchanged if the statements are considered in conjunction with those made by Hilderink (quoted by the Association et al. in its statement of appeal under 75 and 76), to the effect that priority was always given to the safety of Dutchbat troops, and within that framework, to execute the mandate as well as possible. This general communication does not evidence effective control exercised by the State.

12.6 The comments from The Hague cannot be considered separately from a context in which command and control over Dutchbat had not only been transferred to the UN (and was therefore not vested in the State, but solely reserved to the UN) formally, but in which both The Hague as well as the UN and Dutchbat in Bosnia and Herzegovina were very well aware of that transfer in practice when acting and making decisions. This is evidenced by, inter alia, the following statements:

- General Nicolai (PCI interviews, p. 257-259):

"[inquirer: (...) What it boiled down to in actual practice, was that for the Netherlands and for Karremans you were the most direct point of contact.] But not formally. General Gobilliard was the deputy commander. It was Gobilliard who issued the orders and who had to make the decisions. (...) I was present 24 h a day at headquarters [Court of Appeal: of UNPROFOR]. For this reason I was more up to date with all developments. Moreover, Dutchbat was a Dutch unit. Very often, contacts went via me, as communication is easier if it can be done in one's own language. (...) Usually, a sitrep [Court of Appeal: situation report] was issued every 
day anyway, in writing and orally, to both the Crisis Centre of the Royal Netherlands Army and DCCC. (...) Particularly tactical information on how the situation on the ground was developing and how we responded to it, what measures we took [underlining added by the Court of Appeal]. [Inquirer: Could the Netherlands also submit wishes to you then, considering the situation that was developing?] No, certainly not formally. The unit had been placed under the operational control of the UN. For as long as all orders were within the scope of the mandate, the Netherlands had no control whatsoever. The only thing they could have done, if the need made itself felt at all, was ask the Security Council via the political channel if certain things could be executed differently. [Inquirer: So they could not even have submitted any wishes to you (...)? They could have, but only as a friendly request: could you please take this into account? They could not give any orders. [Inquirer: Clearly no orders, but I am concerned with the wishes. Did they attempt to submit wishes to you?] No (...)”

- Voorhoeve (PCI interviews, pp. 623-624):

"[Inquirer: On to the blocking position. (...)] (...) We learnt that this was an order issued by Zagreb, we discussed it, everybody had his opinion about it. Consensus was that we agreed with it, nothing better could have been come up with (...) [Inquirer: (...) You discussed it, but how was it passed on or communicated?] All we could do here in The Hague was comment on it, amongst ourselves. We did not have the right or the authority, nor the political will to thwart it; (...) It was our responsibility to take care of the troops. They were under the command of the UN. We counted on a UN chain of command that was solid. As the crisis developed, it emerged that the UN chain of command showed hitches and was slow. It proved necessary that we started to submit wishes to the UN chain of command. We did so increasingly, but without issuing operational orders. (...) We were lucky that above them [Court of Appeal: above the officers in Tuzla) there was another level, a stronger level, with more countries present, in Sarajevo."

- Van den Breemen (PCI interviews p. 735):

“(...) However, I informed the Minister of my skepsis, but I did believe that the commanders in the field were in charge. (...) The Minister (...) agreed. It is the commanders who are in charge, ultimately, with the proviso that the political wish remained that unnecessary victims had to be avoided. As I remember it this was communicated to the UN. Nicolai phoned me in the afternoon an gave me an update about the latest state of affairs. (...)"

- Hilderink (PCI interviews, p. 212):

"[Inquirer: (...) Did you then get back to Zagreb about the order?] Nee. (...). [Inquirer: (...) Were any orders given to Dutchbat?] No. (...).

12.7 It has been established that the UN gave specific orders to Dutchbat (inter alia about taking up blocking positions). There is no evidence that the State issued specific instructions to Dutchbat, that the State had factual control over UN instructions or that the UN instructions were a response to anything the State said or did. That certain acts performed by Dutchbat followed in time on remarks made by Voorhoeve does not mean that those acts were prompted (in whole or in part) by remarks made by Voorhoeve. 
12.8 By intensifying contacts or communicating wishes more clearly, the State did not exercise control in the sense of effective control over specific acts. Informal consultations do not suffice for that purpose. Nor did the above control exist by virtue of the fact that within the UN chain of command some officers were active (the Association et al. pointed to Brantz and Nicolai particularly) who (also) served as point of contact or even promotor of the Netherlands' interests, for it did not lead to the State becoming part of the UN chain of command, or exerting, as a State, such influence that specific instructions issued by the UN chain of command (such as an instruction to abandon a blocking position) were effectively issued by the State, or partly so.

12.9 Contrary to what the Association et al. argue, discussions in the Prime Minister's office about the use of anti-tank weapons by the blocking positions do not amount to effective control, if only because the Association et al. failed to argue sufficiently specifically that further to these consultations instructions were issued or could have been issued to Dutchbat by the State. The fact that the DCCC met to arrive at an assessment of situations and to formulate guidelines and priorities for the performance of Dutchbat, does not mean that the State exercised or could exercise factual control over specific operational acts or omissions of Dutchbat, not even if the outcomes of the DCCC consultations were communicated more clearly to people within the UN chain of command as the opinion of the Netherlands (as the NIOD reports on p. 2289).

12.10 With regard to effective control by the State, the Association et al. further argue that situation reports containing all important information were drawn up at the time and dispatched to the responsible Ministers in the Netherlands to provide a good idea of the situation in the field, and that a 'confidential situation report' was drawn up between 11 and 21 July 1995. The Association et al. have no access to these reports. They offer proof that an UNPROFOR colonel-commandant stated that these reports should now be declassified, and that the confidential situation report reads: "From the first debriefings of blue helmets who have been released it emerged that male Bosnians had been executed; based on a rough estimate their number was between 50 and 100. (...) It is expected that their findings will not be made public until after Dutchbat's departure from Potočari, so as not to complicate matters."

The Court of Appeal disregards this offer of proof, because its correctness is not relevant for the assessment of the question whether the State exercised factual control in the sense of effective control over the acts performed by Dutchbat during military operations. These reports were dispatched by Dutchbat to the Netherlands, and reported information originating from Potočari. Nothing has been specifically argued to show that these reports may contain instructions issued by the Netherlands.

12.11 In the explanation to their fourth ground for appeal, the Association et al. refer to possible instructions issued by the State in statements made on 16 and 23 July 1995 by General H.A. Couzy and during debriefings, but they are remarks made after the last refugees had been removed from the compound and the mass executions had already finished (or at least almost). For the sole reason of the 
absence of a cause-and-effect relationship with the argued wrongful act, this cannot lead to upholding the claim put forward by the Association et al.

12.12 It follows from the above that no effective control by the State can be inferred from remarks that victims should be avoided and that the safety of the troops had priority. This means that ground 4 put forward by the Association et al. related to the District Court's ruling that, put succinctly, the District Court interpreted the instructions by the State, as argued, too narrowly - is dismissed as unfounded. In view of the above, the Court of Appeal does not get around to the question whether remarks as referred to above had already been made before 9 July 1995, for answering that question could not result in upholding the claim against the State anyhow. The Court of Appeal also disregards the assertion put forward by the Association et al. that the District Court underestimated the importance of issuing instructions with regard to the blocking positions, as the Court of Appeal, as stated before, cannot establish that instructions were issued about the blocking positions from which effective control by the State could follow.

13.1 Ground 5 put forward by the Association et al. relates to the District Court's judgment that the Association's assertion that Dutchbat made too little effort to protect the population in the safe area, does not pertain to acting outside their remit under the mandate on their own authority, but to the operational execution of the mandate under the command and control of the UN (grounds District Court judgment 4.68 and 4.69). The Association et al. pointed out that Dutchbat, as a result of the effective control by the State, acted in contravention of the mandate and the orders issued by the UN. As the Court of Appeal ruled in its assessment of ground 4 that there was no question of effective control as asserted by the Association et al., the fifth ground for appeal does not succeed either.

13.2 In as far as the other grounds put forward by the Association et al. build on the assertions concerning giving priority to the troops' safety, the Voorhoeve instruction and the discussions within the DCCC, these contentions are unsuccessful on account of the above, as well.

Attribution to the State, acting ultra vires

14. The Association et al. further adduced that acts performed by Dutchbat may also be attributed to the State if Dutchbat acted (so-called) "ultra vires". In ground 6 put forward by the Association et al., the Association et al. argued that Dutchbat acted contrary to instruction 9b of the Post Airstrike Guidance (see 2.27 above), and therefore acted ultra vires, by surrendering observation posts without any resistance. The Association et al. argued that the District Court interpreted the Post Airstrike Guidance of 29 May 1995 wrongly, that the District Court made an incorrect estimate of the risk that Dutchbat crews manning the observation posts ran, that the District Court unjustly did not differentiate between the points in time when those posts were surrendered and established facts wrongly, and that the District Court wrongly disregarded important circumstances pointing to collaboration of Dutchbat with the Bosnian Serbs. The State contested these claims.

15.1 In assessing the question whether Dutchbat acted ultra vires in a way that is attributable to the State, the Court of Appeal finds as follows. 
15.2 Not in dispute in this case is that a national contingent placed at the disposal of the UN for UNRPOFOR (such as Dutchbat) is to be considered an 'organ' of the UN. Article 7 DARIO provides:

"The conduct of an organ of a State (...) that is placed at the disposal of another international organization shall be considered under international law an act of the latter organization if the organization exercises effective control over that conduct."

Article 8 DARIO provides:

"The conduct of an organ or agent of an international organization shall be considered an act of that organization under international law if the organ or agent acts in an official capacity and within the overall functions of that organization, even if the conduct exceeds the authority of that organ or agent or contravenes instructions." (underlining added by the Court of Appeal)

It follows from the above that acts conducted by Dutchbat must be considered acts conducted by the UN if they took place 'in an official capacity and within the overall functions' of the UN, even if they ran counter to instructions.

15.3 Only if troops acted beyond the 'official capacity' or the 'overall functions' of the UN organisation ( $C f$. Article 8 DARIO) - so in the case of Dutchbat: beyond the remit of the capacity and functions conferred on it as peacekeeper - it can be concluded that the conduct cannot be attributed to the UN pursuant to Article 8 DARIO. This does not mean, however, that every departure from an order issued by the UN (or a departure from the interpretation of an order) must be attributed as acting ultra vires to a Member State of the UN, besides or instead of to the UN. Nor can this intention be concluded from the explanation given to Article 7 DARIO by the ILO (to which the District Court referred in its ground 4.58). The control of the State over mechanisms such as recruitment, selection and preparation of the troops, and the control of the State over staff matters and disciplinary measures afterwards, as the District Court has pointed out, are not such that by reason of them the in situ operational decisions which deviate from a (higher) UN order are attributable to the State. Essentially, the State had precisely NO controlling powers with regard to operational decisions after the transfer of the command and control.

16.1 Neither did Dutchbat act beyond the 'official capacity' or 'the overall functions' of the UN organisation with regard to operational acts of war, in the opinion of the Court of Appeal. Evaluating the situation in the field was a UN matter. Taking specific decisions about abandoning, reinforcing or recapturing observation posts, about the moment when and the way in which no resistance was put up (anymore) at the observation posts, about taking up or not taking up, moving or removing blocking positions at some point in time, about what to do with their own weapons and the weapons seized, about requesting close air support and the deployment of medical means by the military in the field were all part of the powers and duties of the UN peacekeeper, and were acts in an official capacity and within the overall functions of Dutchbat.

16.2 If specific operational decisions ran counter to the Post Airstrike Guidance of 29 May 1995 or to other (higher) UN orders - about which the parties have a dispute - the ensuing acts cannot be attributed to the State by reason of this alone. With regard to the Post Airstrike Guidance, the Court of Appeal further finds as follows (17.1-17.4). 
17.1 The Association et al. argued that the Post Airstrike Guidance worded two objectives: preventing the loss of lives in the defence of the observation posts, and preventing the exposure of soldiers to being taken hostage. According to the Association et al., Dutchbat acted in violation of both objectives and abandoned observation posts contrary to the order. They believe this can be attributed to the State.

17.2 The Court of Appeal notes that hostages were taken after an observation post had been captured by the Bosnian Serbs. Not in dispute is that Dutchbat soldiers after this takeover could only choose between returning to Potočari or being taken by the Bosnian Serbs as prisoners of war. In the latter case they exposed themselves to the risk of being used as hostages, which was to be prevented. Neither is in dispute that the retreat to Potočari was unsafe because it went straight through (combatting) $\mathrm{ABiH}$ lines. It meant that lives of UN soldiers could be lost during such a retreat, which was (also) to be prevented. In view of this, the choice of the Dutchbat command for one option or the other (in this case: not forbidding them to go with the Bosnian Serbs) was an operational one dictated by the military situation, which was not made beyond the capacity and duty of peacekeeper assigned by the UN, and of which the immediate consequences cannot be considered consequences of acts that are attributable to the State. This remains unchanged although with hindsight this conduct was considered by the French parliament and others a 'tactical error' or in violation of a UN order.

17.3 The Court of Appeal also notes that in the Post Airstrike Guidance no order was issued never to abandon the observation posts. It provided that positions that could be reinforced or recaptured were not to be abandoned, and that isolated positions that could not be supported could be abandoned if under threat and if lives could be lost. It has been established that Dutchbat (in each individual instance) only abandoned the observation posts when fighting troops were thus close that they were considered a threat and gave rise to - at least - the fear of losing one's life. On the spot assessment of how realistic the dangers were, whether supplementary means that had been promised would arrive on time, whether reinforcements were possible and whether it would make sense to engage in gunfight with the Bosnian Serbs, are military assessments, and subsequently decisions that were executed by Dutchbat within the remit of the capacity and duties conferred on it by the UN. These acts cannot be attributed to the State, which did not exercise control over them.

17.4 The assertion that the Bosnian Serbs did not use any type of violence against Dutchbat - if true; there was at least the threat of violence - cannot lead to attribution to the State. The question whether Dutchbat should have opened fire against the Bosnian Serbs should be considered in the light of the objective of the UN mission to keep open through non-violence the option of stability and peace by a temporary neutral presence using deterrence by presence instead of deterrence through strength. For this reason alone, the Court of Appeal cannot find that Dutchbat had a duty to become the enemy of one of the warring parties by force of arms. No decision needs to be made on whether the Rules of Engagement meant that fighting was not only allowed when the soldiers themselves or the population entrusted to their care were targeted and fired at, but was also allowed or an 
obligation when the population that had to be protected was threatened in any other way (as the Association et al. argue and the State contests). Decisions not to open fire (with all that it implied) were (in each case) taken within the UN chain of command, taking into account the capacity and duties of peacekeeper assigned to Dutchbat, without the specific control of the State. The same goes for the assessment (in each case) of the option to impede that arms and equipment were seized when an observation post was occupied.

18. In their explanation to ground 6 , the Association et al. pointed out that Dutchbat soldiers gave driving lessons to the Bosnian Serbs after the surrender of an observation post and seizure of armoured vehicles (see 2.32 above). On the basis of the procedural documents (including the UN Resolutions, the placing at the disposal of Dutchbat and the UN instructions and orders submitted to the court), the Court of Appeal cannot establish that giving driving instruction to one of the warring parties after the surrender of the military post formed part of the peacekeeping duties of UNPROFOR. The Court of Appeal refrains from giving a decision on these acts, because it is not sufficiently argued how these acts could have led to the loss to which the claims of the Association et al. pertain. Without further substantiation (which is not given), the Court of Appeal finds - considering what further happened in this war - that there is no cause-and-effect relationship between driving instructions given in a seized armoured vehicle and the loss suffered by the Association et al.

19. The times of surrender of the observation posts, as referred to but not contested by the Association et al. in their explanation of ground 6, can not change the opinion of the Court of Appeal about the claims against the State. The Court of Appeal will not discuss them any further, therefore.

20. The conclusion is that ground 6 put forward by the Association et al. must fail.

21. Grounds 22 through 25 inclusive put forward by the Association et al. relate to the District Court's judgment that the operational acts of war performed by Dutchbat, which according to the District Court can be attributed to the State, (such as surrendering blocking positions, not abandoning observation posts, and handing over arms and equipment) were not wrongful acts (grounds of the District Court judgment 4.184-4.201). In the above, the Court of Appeal ruled (contrary to the District Court) that the operational acts of war performed by Dutchbat are not attributable to the State. An opinion on the wrongfulness or otherwise of these acts is not relevant, therefore, for the decision of allowing or rejecting the claims of the Association et al. The grounds do not succeed.

22. In view of the non-attributability to the State of the abandoning of the observation posts, ground 43 put forward by the Association et al. does not succeed, either, in so far as it is directed against the District Court's ruling that there is no causal connection between the immediate abandoning of the observation posts and the loss suffered by the appellants. Finally, in view of the above, nor are decisions on the choice of either admitting the wounded to their own military location or transport them or have them transported to other locations attributable to the State. Therefore, the Court of Appeal rules that ground 36 put forward by the Association et al. against the State also fails, and that the connected claim against the State 
(number 434 in the statement of appeal) to rule that Dutchbat acted wrongfully by not providing adequate medical care to the refugees in violation of the UN mission and UN orders, cannot be found for in this case against the State.

Attribution to the State, decision to evacuate on 11 July 1995, role of the UN and the State; transition period from 11 July 199511 p.m.: effective control

23.1 Also in dispute is who took the initiative (the State or the UN) on 11 July 1995 to evacuate the refugees from the mini safe area, and to what extent the State exercised control over Dutchbat in this connection. The Association et al. argued that the State initiated the evacuation, in violation of Gobilliard's order (see 2.45 above). The Court of Appeal finds as follows.

23.2a About the contacts between Voorhoeve and Nicolai on 11 July 1995, Nicolai stated to the Parliamentary Committee of Inquiry:

"After I had informed the Minister of the fact that the air strikes had stopped, he asked if I was aware of the extraction plan for Dutchbat. I answered: "Yes" (...). I informed him that, after careful consideration - which took very little time - we in Sarajevo saw no other solution than evacuating the population, which was present there, entirely unprotected and in wretched circumstances; we had no means to do anything whatsoever about it. For reasons of safety or safeguarding the safety of the refugees we saw no other option than to involve Dutchbat and any other UN resources necessary in that evacuation, because we did not want to leave it to the Serbs. He agreed to it immediately."

From the above it turns out that the UN ("we in Sarajevo") saw no other solution than evacuating the population; the UN (too) had this in mind as the only option.

After this conversation with Voorhoeve, Nicolai phoned Karremans, and, as Nicolai stated: "instructed him to put himself forward to the Serbs so as to organise the evacuation of the refugees (...)."

23.2b On 11 July 1995 at approximately 6.30 p.m. a conversation took place between Janvier and Akashi. They discussed the possibility of evacuation of Dutchbat, but no decisions were taken (NIOD report p. 2432). This was at UN level.

23.2c In the evening of 11 July 1995 Van den Breemen and Van Baal spoke with Janvier, passing on to him the State's wish to withdraw Dutchbat as soon as possible. Van Baal stated about this conversation before the Parliamentary Committee of Inquiry (PCI interviews pp. 344 and 345):

"Of course, we also discussed the idea to recapture the enclave by armed force. This suggestion came from Paris. General Janvier and General Van den Breemen did not think this was realistically possible whatsoever. Three options were discussed. In the first place the option whereby Dutchbat abandoned the enclave because the battalion could not execute its duties any longer. In the second place the option whereby Dutchbat puts up resistance by force of arms. In the third place the option whereby Dutchbat evacuates either together with the population or after the population. Having considered everything option 3 was chosen unanimously. (...) Dutchbat and the population were to evacuate, either together or consecutively. That was agreed as such with General Janvier.

(...) In Bosnia, UNHCR was the highest authority responsible for the refugees. Janvier said very emphatically that it was this organisation which had to provide 
humanitarian aid in first instance, so that the refugees could effectively be relocated to the Muslim Croatian Federation. This had to be achieved through negotiation. Janvier ordered General Gobilliard to liaise with the Serbs as soon as possible at Sarajevo level (...) to give shape to the evacuation and improve the humanitarian situation. Both with UNPROFOR and with UNHCR very explicit agreements were made by General Janvier."

As a witness in the cases of Nuhanović and Mustafić, Van Baal stated on 23 June 2005 that the arrangements concerning departure were a matter of the UN in Zagreb.

23.2d As a witness in the cases of Nuhanović and Mustafić, Nicolai stated on 17 June 2005:

"At that moment [Court of Appeal: late Tuesday evening 11 July 1995, during a telephone conversation with Karremans] I did not discuss it with Gobilliard. I did on Wednesday morning 12 July, during our routine daily meeting. When I spoke to Karremans on the phone, I assumed preparatory measures were already being taken to have transport for the evacuation arranged by the UN." [underlining added by the Court of Appeal]

23.3 Vis-à-vis what has been established in 23.2a-d, the Court of Appeal does not deem of (sufficient) importance that Janvier stated before the French Parliamentary Committee of Inquiry that the Chief of Staff of the Royal Netherlands Army [Court of Appeal: Van den Breemen] told him in Zagreb that the Dutch government demanded that the Dutch soldiers left the enclave by the next morning. Even if this demand was made, it was discussed within the UN alongside other options according to the said statement, and was not agreed to (Dutchbat did not leave the enclave the next morning).

23.4 The assertion that the UN did not want to evacuate the population is not supported by Gobilliard's order (see 2.45 above), either. That order contained the instruction, inter alia, to concentrate the troops in the compound in Potočari. The order does not indicate that the UN did not consider the possibility of an evacuation from the compound in Potočari. Moreover, Gobilliard's order does not affect the agreement reached later by Van Breemen and Van Baal in the evening of 11 July 1995 with Gobilliard's superior General Janvier, which agreement entailed that the population would indeed be evacuated.

23.5 UN Resolution 1004 (see 2.48 above), which asked to respect the status of the safe area of Srebrenica, provides insufficient basis to assume that the UN did not yet want to evacuate on 12 July 1995, but was about to reoccupy the safe area, as the Association et al. argued. This Resolution reiterated what had been agreed before, asked access to the refugees, and prompted the Security Council to adopt measures to restore the status of safe area. In no way does it show that the UN was in the process of forging military plans to reoccupy the enclave - leaving aside the question whether this could have been done safely in the presence of the (too numerous) population. Moreover, the calls in this Resolution were not obeyed at the time (neither by the UN nor by the Bosnian Serbs; see 2.48 above).

23.6 It turns out from a document written by Karremans dated 12 July 1995 , which was submitted by the Association et al. (statement of appeal, exhibit 1), that he was informed (by Mladić), during the negotiations on an immediate ceasefire with the Bosnian Serbs, that in the event of air strikes or close air support, the 
Bosnian Serbs would shoot and kill the entire compound in Potočari, including all Dutchbat personnel and refugees. Karremans also wrote that he was responsible for over 15,000 people within one square kilometre in an extremely vulnerable position ("sitting duck" - with a view of the Bosnian Serb arms), without being able to defend those people. The document constitutes a description of the situation locally at the time. The Court of Appeal holds that the fact that Karremans did not refer to evacuation provides insufficient basis to establish that the decision to prepare an evacuation had not, in the evening before, been made by (inter alia) the UN.

23.7 The letter written by Janvier to Mladic dated 12 July 1995, referred to by the Association et al. in substantiation of their contention that the UN did not intend to evacuate (statement of appeal, exhibit 2), points out that there is an urgent need for water, food, and medical aid, and proposes to allow helicopters with relief supplies to Potočari, and in due time also emergency aid by road. Considering the grave humanitarian situation at that moment (see also 2.44 above) the Court of Appeal can also not conclude from this letter that the UN still intended to keep the population in the mini safe area longer than would be necessary for evacuation purposes.

23.8 Based on these grounds the Court of Appeal finds that the decision to evacuate Dutchbat and the refugees came about by mutual consultation between Janvier on behalf of the UN on the one side, and Van den Breemen and Van Baal on behalf of the State on the other. In so far as the Association et al. argue in ground 7 that the State, after the fall of the safe area, took over control from the UN and initiated the evacuation of the refugees contrary to Gobilliard's order (represented in 2.45 above), this ground fails.

24.1 In the newly developed situation in which Srebrenica had fallen and the UN mission had essentially failed, the State decided together with the UN to evacuate the population from the mini safe area. The Dutch government participated in this decision-making process at the highest level.

24.2 With this decision a transition period set in, in which operations in Potočari were wound up and Dutchbat would focus on its humanitarian task and the preparation of the evacuation of Dutchbat and the refugees from the mini safe area. To that extent, the State had effective control. That the State had factual control over other, specific conduct has not been put forward. Ground 7 put forward by the Association et al. must fail. This means that the Court of Appeal will proceed on the basis of the time established by the District Court as the moment the transition period set in, i.e. 11 July 1995 at approximately 11 p.m. The Court of Appeal will also uphold the District Court's opinion that, having taken the decision together with the UN not to withdraw Dutchbat any earlier than at the same time as, or after, the evacuation of the refugees, the State combined the exercise of its power to withdraw with giving humanitarian aid to and (preparing) the evacuation of the refugees in the mini safe area during the transition period (District Court grounds 4.80-4.85).

24.3 In order to clarify matters, the Court of Appeal notes that the State's control, essentially, was limited to the evacuation of the population and the withdrawal of Dutchbat. Whether it would have been feasible and desirable to oust the Bosnian Serbs by engaging in combat in the presence of thousands of refugees was a matter of military assessments and decisions that had to be taken within the UN chain of 
command also, possibly in consultation with NATO. The Court of Appeal further refers to the ground given below under $44.2 \mathrm{~b}$. By this reason alone, ground 34 of the Association et al. cannot succeed in so far as it is directed against the opinion of the District Court that Dutchbat could not protect the refugees in and around the part of the mini safe area that was situated outside the compound on its own authority, without outside help. Moreover, the Court of Appeal assumes that the Bosnian Serbs could have outnumbered Dutchbat and the refugees by heavy odds; in this connection cf. ground $67.1 \mathrm{~b}$ below. In view of this, ground 37 put forward by the Association et al. concerning the handing over of arms by Dutchbat soldiers on 12 and 13 July 1995 must fail as well, since the State could not have engaged in fight independently with the Bosnian Serbs even without this handover.

24.4 In so far as ground 8 of the Association et al. built on the previous grounds for appeal, it shares their lot.

Attribution to the State, advice to flee into the woods, admission of refugees to the compound: no attribution

25. Based on the above, the Court of Appeal holds (as did the District Court in its ground 4.87) that the State had effective control during the transition period over granting humanitarian aid to and (preparing) the evacuation of the refugees in the mini safe area, so that Dutchbat's acts in that respect can be attributed to the State, and that effective control did not pertain to the stream of refugees moving from the city of Srebrenica to the mini safe area before the transition period set in, nor to the refugees or Dutchbat's acts outside the mini safe area.

Based on the above grounds, the Court of Appeal, contrary to the District Court, does not attribute the mere acting in violation of a UN order (such as Gobilliard's order)to the State as acting ultra vires. There is no ground for attribution to the State of acts performed before the evacuation decision of 11 July 1995 and outside the mini safe area.

26.1 Considering the above, the question whether or not Dutchbat soldiers advised Bosnian men to flee into the woods (the men referred to above under 2.43), and if so, whether this was in violation of the substance of Gobilliard's order, may remain unanswered by the Court of Appeal. There is no evidence that the State had any factual control (and therefore effective control) over such instructions. In view of the findings in 12-17 and considering that no facts or circumstances have been put forward to the contrary, it must be considered, too, that when the flow of refugees started and then continued to swell until (no later than) 11 July 1995 at 11 p.m., Dutchbat soldiers took up positions and carried out activities within the remit of their (readily visible) capacity and duties of UN peacekeeper, and based on the assessments of situations made by their superiors within the UN chain of command for the purpose. The instructions given to the male Bosnian Muslims until that time were, therefore, also given during the exercise of their UN duties. Laying down and handing in arms while informing the Bosnian Serbs of this was also done in that capacity, without the control of the State.

26.2 The Association et al. argued in their explanation of ground 9 that Dutchbat instructed the Bosnian men to flee into the woods even after the start of the transition period. However, they failed to substantiate this claim in the face of the 
State's assertions giving reasons (also presented and discussed in District Court judgment grounds 4.103-4.105), and did not offer sufficiently specific proof. The Court of Appeal therefore assumes that these instructions were not given (or no longer given) then, so that the Court of Appeal does not get round to a discussion of the question whether such instructions during the transition period were (also) attributable to the State.

26.3 In their explanation of ground 8 the Association et al. accuse the State of the fact that Dutchbat had not raised the alarm about the flight of the Bosnian men into the woods. Leaving aside whether this omission is attributable to the State, it does not constitute a wrongful act in the opinion of the Court of Appeal, for there is nothing to indicate that the State was or should have been aware that the fate of these men would be different from that of other refugees who had not come to the mini safe area. There was no reason at the time, therefore, to raise the alarm from the mini safe area about the (alternative) route of these men. In so far as men wished to join the $\mathrm{ABiH}$ in fighting, the Association et al. cannot blaim that on the State either.

26.4 It follows from this that ground 33, in which the Association et al. argued that Dutchbat should have raised the alarm about the men in the woods as soon as Dutchbat was aware of the 'serious risk' of genocide (Court of Appeal: or of death). In fact, occupants of the enclave and refugees had told Dutchbat in the night of 11 to 12 July 1995 that most young men and fighters had left the enclave to force a breakthrough themselves (statement of Rutten before the Parliamentary Committee of Inquiry, PCI interviews p. 45).

27.1 In so far as the Association et al., at the end of their explanation of ground 8, contest the opinion of the District Court that not admitting any more refugees to the compound even before 11 July 1995 cannot be attributed to the State, the Court of Appeal finds as follows.

27.2 It is established (see 2.37 and 2.42 above) that in the early evening of 10 July 1995, the UN commanders on the scene (Karremans and Franken) decided to admit as many refugees to the compound as would fit into the large vehicle halls within the compound, and that this was approximately 5,000 people eventually. As UNPROFOR commanders, Karremans and Franken had to make this decision, and as commanders within the UN chain of command they had to assess the on-site security situation and possibilities as well as means for protection. Within the UN chain of command they had to follow and give (UN) instructions about the numbers and the place of shelter. They acted within their capacity and duty of UN peacekeeper. The State had no control over this decision at the time - neither over admitting refugees, nor over the number of refugees to be admitted, nor over where they could enter (through a hole in the fence). The decisions about these issues cannot be attributed to the State.

28. Ground 9 (in so far as not yet discussed above) and ground 10 of the Association et al. further pertain to the abandoning of observation posts, the fleeing of Bosnian men into the woods, the scope and meaning of Gobilliard's order and the interpretation of the concept of effective control. Considering what has been found above, these grounds cannot succeed. 
Attribution to the State, deployment of air power, French Tigre helicopters: no attribution

29.1 Grounds 11, 12, 13, 14, and 15 of the Association et al. pertain to decisions to request or terminate the deployment of air power and the fact that the State did not accept France's offer on 10 July 1995 to deploy French Tigre helicopters plus crew for the purpose of reoccupying the enclave (District Court judgment grounds 4.119-4.143).

29.2 No facts or circumstances have been put forward on the basis of which it can be established that others than those within the UN chain of command and NATO, as referred to in 2.15, exercised factual control over specific (preparations for) requests for close air support and specific implementing acts to that end, or over the deployment of Tigre helicopters. The military and humanitarian assessments about the feasibility and possible consequences of (continued) close air support were made within the UN and NATO, and that is where the decisions were made.

29.3 The Court of Appeal sees no ground, neither was one put forward by the Association et al., for considering the State authorised to deploy or have deployed independently fighter planes or helicopters above the territory of Bosnia and Herzegovina in order to reoccupy the enclave in that manner. The Court of Appeal follows the District Court therefore in its opinion that agreement and synchronisation about close air support had to be reached first within the UN and NATO (see District Court judgment, ground 4.139).

29.4 With regard to close air support no facts or circumstances were put forward to support the conclusion that the State had effective control over whether Dutchbat requested close air support at any point or not.

29.5a Specific orders issued by the State by which the State prevented Dutchbat to request close air support have not been put forward.

29.5b Neither has it been established that the State prevented that requests for close air support were honoured.

The State pointed to Voorhoeve's statement to the Parliamentary Committee of Inquiry, containing, inter alia, (PCI final report pp. 192 and 193):

"When the situation came to a head and it became progressively clear that the Serbs were looking to conquer more than the south corner of Srebrenica, I consulted with General Van Kolsteren, Janvier's Chief of Staff. He asked me, literally, whether the Dutch government objected to deploying air power, since by then 30 to 35 Dutch soldiers had fallen into the hands of the Serbs and could get killed as hostages. (...) I immediately (...) told him: close air support is inevitable, the UN cannot NOT give close air support."

Voorhoeve implicitly indicated not to object to close air support, and left it to the UN to give close air support. There was no question that the State prevented or stopped close air support, in so far as this was possible at all.

29.5c On 10 July 1995, Nicolai indicated that he wished to keep airplanes at his disposal (NIOD report p. 2180). At 12.00 noon (on 10 July) Nicolai and Zagreb discussed the positions of the Hague with regard to close air support. In the discussion, it was confirmed that close air support was available. This does not indicate that the State prevented or stopped close air support. 
29.6 It does not follow from the Association et al.'s allegation that Voorhoeve exerted influence on NATO decisions (which influence the State contested) that military operations are attributable to the State. Both close air support and air strikes required the consent of NATO, to which the Netherlands is a member state. Within NATO a member State can make known its position and, on the other hand, pressure may or may not be exerted on the member state to adopt a different view. From this, it does not follow that the NATO decision is attributable to the member state. Article 59, paragraph 2 DARIO provides as follows:

"An act by a State member of an international organization done in accordance with the rules of the organization does not as such engage the international responsibility of that State under the term of this article."

The fact that a member state may express an opinion within the international organisation (in conformity with the rules), does not mean that decisions made by the international organisation are attributable to the member state. Decisions about air strikes and close air support were joint military operational choices of the UN and NATO, prompted by assessments of humanitarian developments, threat of war and on-site risks, and by the role and position of the UN and NATO member states both in this civil war as well as worldwide. In the process, member states may have a say politically, to a greater or lesser extent, without taking over decision-making (wholly or partially) from the UN or NATO. That NATO attempted unsuccessfully to exert pressure on the Netherlands to allow air strikes, as the American diplomat Holbrook wrote in his memoires, or that the UN interrupted or cancelled close air support after a telephone conversation on the subject between Voorhoeve and Akashi, does not mean that terminating close air support can be attributed to the State as a consequence of a (wrongful) act by the State.

29.7 In their explanation of ground 12, the Association et al. argued that the State stated deceitfully that the population and their own troops were at risk in the event of an air strike because they were intermingled with the Bosnian Serbs. The Court of Appeal dismisses this argument and leaves unanswered whether the statements as asserted were made at the time. From the documents in the case and from what the Association et al. put forward themselves, it emerged that the Bosnian Serbs (on each occasion) drew up very closely to the military positions (and even took them over), and that the fleeing population was dispelled ahead of the Bosnian Serbs. Under those circumstances, the Court of Appeal cannot rule that the statement as asserted, that the population and the Dutch troops were at risk in the event of airbombing the Bosnian Serbs, is deceitful, and could not or should not have played a role, therefore, in the decision-making process of the UN and NATO about air strikes and close air support.

29.8 Nothing has been put forward to indicate that there was any interference, except the opportunity to express within the UN or NATO (urgent) wishes as a (relevant) UN or NATO member state. Considering the above, the Court of Appeal, like the District Court, dismisses the offer of the Association et al. to furnish proof for this argument by examining witnesses (statement of appeal sub 225).

30. The same applies, mutatis mutandis, for the deployment of the French Tigre helicopters. 
31. It follows from the above, in conjunction with the grounds given below in $44.1 \mathrm{ff}$. with regard to the allegation that the State failed to report immediately the war crimes that had been observed (which allegation the Association et al. also set out in grounds 14 and 15), that grounds 11 through 15 put forward by the Association et al. fail. Ground 16 put forward by the Association et al. builds on their previous grounds, and cannot succeed either, therefore.

\section{Interim conclusion}

32.1 With the above the Court of Appeal ruled that the (military) operational acts of war performed by Dutchbat which are in dispute were performed without factual control of the State over specific acts, and within 'the official capacity' and 'within the overall functions' of these UN troops. Therefore, these acts performed by Dutchbat cannot be attributed to the State as wrongful acts, nor as acting ultra vires, so that all grounds related to attributing such acts to the State are dismissed as unfounded.

32.2 On 11 July 1995 at 11 p.m. the State and the UN decided to have Dutchbat provide humanitarian aid and organize (the preparation of) the evacuation of the refugees in the mini safe area. At that moment the transition period sets in, in which the State had effective control over acts performed by Dutchbat in relation to the humanitarian aid and the evacuation of refugees in the mini safe area.

\section{Wrongful acts on the part of the State (Dutchbat)}

Applicable law, framework for assessment, criterion, terminology

Applicable national law

33. The Court of Appeal notes that the District Court ruled that the claim put forward by the Association et al. asserting wrongful act on the part of the State must be assessed under the law of the Netherlands (District Court judgment, grounds 4.166-4.171). In appeal no ground was adduced against this ruling, nor is it (in other respects) in dispute which law is applicable. Therefore, the Court of Appeal will decide on the basis of the law of the Netherlands what the scope is of the obligation arising from a wrongful act.

\section{Direct effect of the Genocide Convention}

34.1 In ground 19 the Association et al. argue that the Genocide Convention has direct effect. Based on the procedural documents in this (civil) case they are referring to Article 1 of the Genocide Convention. The State contested the Association et al.'s claim. The Court of Appeal finds as follows.

34.2 Article 1 of the Genocide Convention (the 'Convention on the Prevention and Punishment of the Crime of Genocide', which came into effect on 12 January 1951), provides:

"The Contracting Parties confirm that genocide, whether committed in time of peace or in time of war, is a crime under international law which they undertake to prevent and to punish."

34.4 The Court of Appeal states first and foremost that in this situation it was not the State (Dutchbat) that either committed genocide or should punish it. The deadly violence was committed by the Bosnian Serbs, not Dutchbat or, in another sense, the State. The allegation made by the Association et al. is that the State did not prevent the genocide committed by the Bosnian Serbs. 
34.4 The obligation to 'prevent genocide' is not described exactly; for the prevention of genocide various (preventive and repressive) modes of action are conceivable. Article 1 does provide that the contracting parties undertake to prevent genocide, but does not indicate how they should do so. Article 5 of the Genocide Convention clarifies that further rules are required to that end:

"The Contracting Parties undertake to enact, in accordance with their respective Constitutions, the necessary legislation to give effect to the provisions of the present Convention, (...)".

Tangible, specific obligations to prevent are not included in the Convention. A 'best efforts obligation' "to take all measures to prevent genocide which were within its power" as the International Court of Justice ruled in the case of Bosnia and Herzegovina v. Serbia and Montenegro on 26 February 2007 (by which obligation all member states are bound), does not impose any specific obligations which may be enforced directly by a national court in a dispute between a citizen and the State. This is not altered by the 'Basic Principles and Guidelines on the Right to a Remedy and Reparation for Victims of Gross Violations of International Human Rights and Serious Violations of International Humanitarian Law' (UN Resolution 60/147 of 16 December 2005). The preamble to these Basic Principles emphasizes that they do not contain any new legal obligations, but only identify and model what already exists.

34.5. The invocation of (some provisions in) the Geneva Conventions and the First Additional Protocol in this respect fails for the same reason. These provisions only have effect between states, and are not suitable for application by a national court in the relationship between citizen and government due to their general and insufficiently specific wording (also pertaining to the intended result). The fact that these provisions (as well as the Genocide Convention) purport to (inter alia) protect individual citizens does not mean that they have direct effect. The State rightly points this out.

34.6 Considering the above, the Court of Appeal will not give a declaratory decision on the claim put forward by the Association et al. that the State breached its obligations to prevent genocide as referred to in Article 1 of the Genocide Convention. Ground 19 put forward by the Association et al. must fail in this respect. Ground 21 put forward by the Association et al. which also seeks a declaratory decision with regard to genocide, shares the same fate.

Direct effect of the obligation to protect under the mandate

35.1 Ground 17 of the Association et al. is directed against the District Court's ruling that the mandate given to UNPROFOR has no direct effect. According to the Association et al. the UNPROFOR mandate did not just create powers, but also imposed the obligation to protect the population.

35.2 The Court of Appeal notes that the UNPROFOR mandate pertained to creating conditions for peace and security which are necessary for negotiations to achieve a peaceful political solution (see 2.3 above). Troops would be present in designated areas to deter attacks against the safe areas, monitor the ceasefire and promote the withdrawal of (para) military units (UN Resolution 836 item 5, see 2.13 above). As was considered above under 9.4.1, protection of the population as such was not defined explicitly as an UNPROFOR task. Nor has it been indicated in what 
manner the population should be protected except by the presence of neutral UN troops. Provisions about specific acts to warrant the safety of citizens that individuals could invoke are not included in the relevant UN Resolutions. Therefore, no provisions exist that could be considered to be an objective right to the protection as proposed by the Association et al. Therefore, the Court of Appeal will uphold the District Court's ruling that the UNPROFOR mandate did not create any obligations to UNPROFOR, Dutchbat, or the State that can be enforced at law by the Association et al. (District Court judgment, ground 4.149). Ground 17 put forward by the Association et al. is dismissed as unfounded.

\section{SOP 208 and Geneva Conventions}

36.1 The Court of Appeal already found in the above that the mandate to UNPROFOR did not create any independent rights of action for the Association et al. (see grounds $9.1 \mathrm{ff}$. and 35.2 above), and that the Association et al. cannot rely on the provision in the Genocide Convention invoked by them (ground $34.1 \mathrm{ff}$ ).

36.2 SOP 208 and the Geneva Conventions contain the obligation to report any war crimes observed. As will be considered below in grounds $44.2 \mathrm{ff}$., failure to report the observations (whether true or not) did not lead to inhumane treatment or loss of lives. For this reason alone, SOP 208 or the Geneva Conventions cannot lead to upholding any claims put forward by the Association et al. (by themselves or in conjunction with other violations). In so far as ground 1 put forward by the State also relates to this, it fails in the absence of an interest.

\section{Competence within the meaning of the ECHR and ICCPR}

37.1 The Association et al. argued that the State breached its obligation to the population by contravening provisions of the ECHR and ICCPR. To establish violations of the ECHR and ICCPR the question of whether the State (via Dutchbat) was competent within the meaning of Article 1 ECHR and Article 2 ICCPR should be considered. In order to consider the question whether this competence existed outside the compound, as the Association et al. defended in ground 18, the Court of Appeal finds as follows.

37.2 A State has jurisdiction within its territory. It has jurisdiction beyond its national borders only in exceptional instances. Jurisdiction in this case is jurisdiction beyond the Dutch national borders, namely in Bosnia and Herzegovina, in and outside the compound in Potočari.

37.3 Not in dispute between the parties is that the deployment of Dutchbat was not the exercise of the State of 'public powers' in the form of 'executive or judicial functions' in Bosnia and Herzegovina. As a constituent part of UNPROFOR, Dutchbat was only a military peacekeeping force. As has been established based on what the Court of Appeal found before, Dutchbat operated within the command and control structure of the UN with regard to military operations in Bosnia and Herzegovina. The SOFA (see 2.12 above) was an agreement between the UN and Bosnia and Herzegovina, under which no State powers can be derived per se. The State exercised no power of control over acts performed by Dutchbat in the performance of its UN duties. Dutchbat had been put at the UN's disposal. Its acts and omissions were governed within the UN chain of command. The effective control - as referred to within the context of the question of jurisdiction, and as such 
to be distinguished from effective control within the context of the question of attributability - was vested in the UN.

37.4 Not under discussion (considering, inter alia, what has already been found previously in this judgment) are acts performed by Dutchbat soldiers (individually or in a group) vis-a-vis the population outside the compound which were not part of UN military operations, except the evacuation, which will be dealt with below. Neither did a situation exist in which Dutchbat placed people under its control by violence or force (for instance, by obliging people to stay with the troops).

37.5 Dutchbat's position in the area at the time of the wrongful acts complained of, entailed that Dutchbat as UN peacekeeper should protect the population not better or differently than it did according to the operational assessments of the UN commanders, so by, inter alia: not opening fire and (each time) withdrawing. It is not up to this Court of Appeal to judge on the conformity of UN conduct, based on decisions made within the UN chain of command and on the relevant UN Resolutions, under the ECHR. This might be different in the event of manifestly wrongful UN orders and conduct, but they do not include orders or conduct arising directly from decisions not to turn against people with deadly (armed) force.

37.6 Upon the withdrawal of Dutchbat and, consequently, the advance of the warring parties in the safe area, Dutchbat was not (or at least no longer) dominant in the area outside the compound. The possibility for Dutchbat to request close air support did not mean it had a dominant position, for the sole reason that not every request for close air support was granted. Actual authority over the population outside the compound did not exist anymore during the retreat of the troops.

37.7 Therefore, the State had no jurisdiction over the population within the meaning of the ECHR and ICCPR. Ground 18 put forward by the Association et al. is dismissed as unfounded.

38.1 To address the question whether the State (via Dutchbat) did have jurisdiction within the meaning of Article 1 ECHR and Article 2 ICCPR within the compound, which the State challenged in its ground 2, the Court of Appeal considers as follows.

38.2 As has been considered above, it is established that the State had effective control over acts performed by Dutchbat when giving humanitarian aid and (preparing) the evacuation of refugees in the mini safe area. Acts performed by Dutchbat itself in the mini safe area with regard to the evacuation of refugees can be attributed to the State, therefore, from the moment the decision to evacuate had been taken (11 July 1995 at 11 p.m.).

38.3 The presence of Dutchbat in Srebrenica and in the compound in Potočari arose from the participation of the Netherlands in UNPROFOR; while UNPROFOR derived its authority to act in Srebrenica from the SOFA agreed between the United Nations and Bosnia and Herzegovina (see 2.12 and 37.3 above). This entails that when the transition period set in and the State undertook the evacuation together with the UN, the State, via Dutchbat, had jurisdiction in the compound within the meaning of Article 1 ECHR and Article 2 ICCPR.

38.4 Based on the procedural documents and the arguments put forward by the parties, the Court of Appeal assumes that after 11 July 1995 at 11 p.m. the State did 
effectively exercise the said jurisdiction in the compound. The Court of Appeal considers as follows in this respect.

The compound was enclosed by a fence. Dutchbat soldiers (only Dutch military personnel) stayed within the compound together with refugees. The UN mission had effectively ended, and the State was authorised to withdraw the troops, whereby the exercise of this authority was linked to the evacuation (see 24.1 and 24.2 above). Bosnian Serbs or other warring parties were not present in the compound. Dutchbat decided (from within the UN chain of command) that no more refugees were admitted to the compound when the vehicle halls were full; subsequently no more refugees got in. There are no indications that the Bosnian Serbs issued orders to the refugees in the compound. Neither did this occur during the brief inspection carried out by VRS soldiers in the compound on 12 July 1995, referred to in the NIOD report (on p. 2640). The refugees in the compound and in front of 'the corridor' allowed themselves to be led by Dutchbat. The State could issue further instructions to Dutchbat via Nicolai (who, after the decision to evacuate, had also become authorised negotiator on behalf of the State) and Karremans about how to act in the compound and concerning the evacuation. Dutchbat had actual authority over the refugees in the compound and, during the evacuation, in front of the corridor, and was dominant for as long as there occurred no fighting (which was not the case). With this last addition the Court of Appeal points out that jurisdiction did not depend (as the State appears to assume; statement of appeal, 4.2.16) on what could have happened if the compound had been fired at. The threat of becoming under fire may well carry with it the threat of loss of jurisdiction, but does not take away that jurisdiction per se.

38.5 It does not follow from the very threatening situation that the compound was within shooting range of the Bosnian Serbs and could not be reached by UN buses and other emergency relief supplies on time, that as a result the State no longer had jurisdiction over the compound. In so far as this situation demanded action (staying out of sight of the Bosnian Serbs in the vehicle halls and distributing what little water was available, for instance), the instructions issued by Dutchbat in the compound were obeyed. When groups were formed, Dutchbat instructions were obeyed as well. The State argued that the Bosnian Serbs used physical violence against refugees and disarmed Dutchbat soldiers, but it turned out from the NIOD report on which the State based its claims that this happened outside the compound (NIOD pp. 2647 and 2648) and not when groups were formed to go on to the corridor'; at least, the State has not substantiated claims to the contrary. This does not change the jurisdiction within the compound sufficiently, therefore. An inspection of the compound after the evacuation of the refugees does not affect the jurisdiction of the State (via Dutchbat) in the compound shortly before and during the evacuation, over the people who were there at the time.

38.6 Considering all this, the Court of Appeal also rules that the State (via Dutchbat) did have jurisdiction within the meaning of Article 1 ECHR and Article 2 ICCPR within the compound (during the period relevant to this dispute) (as the Supreme Court ruled on 6 September 2013 in the cases of Nuhanović and Mustafić et al., ECLI:NL:HR:2013:BZ9225 and ECLI:NL:HR:2013:BZ9228, Supreme Court 
judgment, ground 3.17). Ground 2 put forward by the State is dismissed as unfounded.

38.7 The Court of Appeal notes, no doubt superfluously, that even if the ECRH and ICCPR provisions referred to below are not applicable to acts performed by Dutchbat due to absence of jurisdiction, this would not alter the assessment of the disputed claims. The said standards, derived from the ECHR and ICCPR, are also implied in the law of the Netherlands, in the sense that a breach of those standards must be considered to be in violation of the generally accepted standards of due care.

Criterion; cautious review?

39.1 Ground 1 put forward by the State, partly discussed in 36.2 above already, is further directed against the District Court judgment that there was no reason for a cautious review of the acts performed by Dutchbat on the ground that a situation of war existed (District Court judgment, 4.181). In the State's opinion, the fact that the subject under discussion is whether Dutchbat 'could reasonably act and decide like it did' implies that the court should review with caution in situations of war. The Association et al. contested this. The Court of Appeal finds as follows.

39.2 In the cases under consideration, invocation of wrongful act within the meaning of Article 6:162 Dutch Civil Code ('DCC') is what is at issue. Therefore, the Court of Appeal assesses whether there is a violation of a right, an act or omission breaching a duty imposed by law, and/or an act or omission breaching a rule of unwritten law pertaining to proper social conduct (generally accepted standards of due care). Within that context, the Court of Appeal also reviews whether Dutchbat could reasonably decide and act like it did. There is no ground for (farther-reaching) cautiousness when assessing the said matter. Ground 1 put forward by the State is dismissed as unfounded. Another matter is that the Court of Appeal, like all courts, considers all the facts and circumstances found in the case in its assessment. Therefore, in its review, the Court of Appeal does find relevant that Dutchbat operated in a war situation and had to take decisions under a great deal of pressure.

40.1 Ground 20 put forward by the Association et al. is directed against the District Court's judgment that the troops, whose duty it was to protect the refugees in the safe area, should have protected the right to life and right to integrity of the human body of these refugees under Articles 2 and 3 ECHR and 6 and 7 ICCPR 'to the extent this could reasonably be required'. In the opinion of the Association et al. this last restriction is incorrect; and that this is about 'failure to take measures that could reasonably be expected'.

40.2 Since this judgment on appeal, as indicated in 39.2 above, having regard to the situation and all circumstances of the case, reviews whether the State acted as it was authorised to do (including taking measures) whereas it was aware or should have been aware of the real and immediate dangers to the refugees, the ground, whatever implications it may otherwise have, cannot succeed.

\section{Numbers and terminology}

41.1 Ground 26 put forward by the Association et al. is directed against the District Court's finding that there were approximately 150 Dutchbat soldiers in the 
compound (District Court judgment, in 4.204). According to the Association et al. at least double that number of Dutchbat soldiers were present there. They consider this important because of the District Court's judgment that Dutchbat, due to its limited manpower, was not capable of protecting the population without outside help against the superior military strength of the Bosnian Serbs.

41.2 It has been acknowledged between the parties that there were (approximately) 430 Dutchbat troops present in the compound around 12 July 1995 (statement of appeal by the Association et al., in 339, and Statement of Defence by the State, in 8.3.6). Ground 26 put forward by the Association et al. succeeds in this respect. It is not clear, however, how many of them were combat soldiers, equipped to protect the population against a military force. The NIOD report refers to a number of between 150 and 200 (NIOD report p. 2167 and p. 2625). The Court of Appeal does not consider it important to any decision in the present cases whether there were 150 or double that number of Dutchbat soldiers present in the compound to protect the population against the military force of the Bosnian Serbs, as will be dealt with in more detail below in $67.1 \mathrm{~b}$.

42.1 Grounds 27 and 28 put forward by the Association et al. relate to the number of men who had taken refuge within the mini safe area, and the number of men in the compound. It has been acknowledged between the parties that the exact number of men is unclear. The District Court mentioned 'probably around 2,000 men', of whom 'three quarters between the ages of 16 to 60', and 'at least 300 men in the compound', 'between 600 and 900 men elsewhere in the mini safe area' and, in the compound, Franken's list containing '251 names' plus 'some 70 men' who refused to have their name taken down on the list. The Association et al. submitted that there were some 2,000-3,000 men and boys present. The Association et al. do not want to be bound by numbers, anyway, as the numbers will become apparent at the time of the individual actions to assess the damages, the Association et al. put it.

42.2 The Court of Appeal will not establish the exact number of men as it is not necessary in order to deliver a judgment. In the present case the Court of Appeal will proceed on the principle that the exact number is unknown and that it is possible that there were 3,000 men in the mini safe area and 350 men and boys in the compound at the start of the evacuation. The grounds succeed in this respect.

43. Ground 39 put forward by the Association et al. relates to the terminology used. According to the Association et al. the correct term would not be 'evacuation' but 'deportation', because the removal of the population was a forced and unnecessary movement in which Dutchbat should not have participated. To substantiate this, they follow on from what they had put forward unsuccessfully in the grounds discussed earlier, and refer to the considerations in the ICTY judgment in the case against Krstić of 2 August 2001 (IT-98-33-T), which held that the object of the evacuation was not to bring the population to safety but to remove them. In the opinion of the Court of Appeal, reference to this judgment cannot be successful, because that case centres on acts performed by the Bosnian Serbs. That there was no necessity for the Bosnian Serbs to chase the refugees from their homes and make them leave the area, and that the evacuation took place in an 'atmosphere of terror' does not prejudice the fact that the UN and Dutchbat were faced with people who were expelled (unnecessarily and forcibly) by the Bosnian Serbs. As a result, these 
people were cut off from sustenance, and a shelter needed to be found for them. For this reason, the Court of Appeal will use the word evacuation hereinafter (for the overall assessment of the case it does not make a difference which word is used). Ground 39 does not succeed, therefore.

\section{Wrongful acts, substance}

Not reporting observed war crimes immediately

44.1 The Association et al. argued that the observed war crimes had, wrongly, not been reported, and that the reporting of war crimes would have led to military and political interference, or at least would have brought protective measures a step closer. They pointed out that Dutchbat soldiers had observed war crimes as early as 10 July 1995, namely that the VRS in its advance set houses along their route on fire, and, shooting, routed fleeing people.

44.2 The Court of Appeal finds that failure or otherwise to report these crimes by Dutchbat does not affect the decisions to be made in the cases under consideration, for the UN was well aware that the Bosnian Serbs advanced on the safe area by force, and the UN also understood that this violent advance had to be stopped (on 9 July 1995, the UN have issued orders to take up blocking positions against the advance of VRS, see 2.34 above). There is nothing to indicate (and it has not been argued sufficiently) that further reports, then or a few days later, about the specifics of this violent advance and the atrocities that accompanied it (such as rape and then slitting throats), would (or could) have led to timely liberation or sufficient protection of the area by the UN or NATO.

44.2a In view of, inter alia, the statements referred to in $23.2 \mathrm{a}$ and c, no facts or circumstances have been put forward that can lead to the conclusion that the UN (or NATO) planned to reoccupy the safe area by force of arms, and, if they had been prepared to do so by virtue of reports of war crimes observed by Dutchbat, that the safe area would have been reoccupied in due time (so within a matter of days instead of weeks later) and the war crimes would have been prevented. The Court of Appeal finds, as did the District Court, that the passage from the UN report, namely: "It is possible that if members of the Dutch battalion had immediately reported in detail those sinister indications to the UN chain of command, the international community may have been compelled to respond more robustly and more quickly, and some lives might have been saved", and a quote from the NIOD report from which the Association et al. infer that a considerable number of troops was held ready within the context of (for instance) a Rapid Reaction Force, carry insufficient weight set off against the practical impediments and obstacles to timely military intervention and the existing hesitations about this within the UN and the international community.

44.2b Janvier informed the Secretary-General on 16 July 1995 that reoccupation of the safe area was not within UNPROFOR's power, the more so because action would have to be taken within sight of a hostile population and would very likely lead to all-out war with the Bosnian Serbs and possibly even Yugoslavia, because NATO would have to attack the integrated air (and missile) defence system (NIOD report, p. 2429).

44.2c In this connection the Court of Appeal also notes that, after the war crimes had become public knowledge and the mass executions had been proved on 10 
August 1995, it took until 30 August 1995 until air strikes and bombings were carried out between 30 August and 20 September 1995 by NATO and the Rapid Reaction Force under the name of Operation Deliberate Force. In this light, the argument that the Rapid Reaction Force, although not at full strength at the time (as the Association et al. acknowledge, see statement of appeal, 241) would have played a significant role at the time of the executions before 17 July 1995, if all war crimes that had been observed had been reported immediately, is, without substantiation (which is absent) not plausible.

44.3 Furthermore, it cannot be established in light of what emerges from the procedural documents that a 'cumulative effect' of further reports on 12 and 13 July 1995 would have resulted in timely intervention by the UN or NATO. In addition to the above, the Court of Appeal finds as follows in this respect (in 44.4-44.6).

44.4 It has been established that the UN was aware of the appalling circumstances in which the refugees had been forced by the Bosnian Serbs (crammed into a fighting zone and cut off from relief convoys). Also, the UN chain of command knew that on 12 July 1995, the Bosnian Serbs transported the men separately and prevented that Dutchbat escorted them (District Court judgment 4.267; see also NIOD report p. 2652). On 13 July 1995, the find of nine bodies was reported to the UN (see 2.55 above). None of this led to sufficiently rapid military or political intervention by the international community.

44.5 The majority of the war crimes and executions at issue occurred during and immediately following 12 and 13 July 1995, in the period up to and including 17 July 1995. On appeal, too, there is no basis for the conclusion that the international community could have prevented these crimes if it had had more tangible and more specific knowledge of them. The passage from the UN report quoted in $44.2 \mathrm{a}$ above only mentions an uncertain and vague chance of saving some lives, in an unspecified manner. This does not outweigh the practical impediments and obstacles to timely military intervention and the existing hesitations within the UN and the international community.

44.6 How the impending genocide could have been prevented apart from by military intervention has not been explained sufficiently on appeal, either. The Association et al. suggest the option of adopting a new, more stringent resolution in the Security Council, sending a sharp warning to potential perpetrators, exchanging prisoners of war and sending more UN observers. The Court of Appeal finds insufficiently plausible - and it has not sufficiently been argued - that this could have been realised at such short notice and with such effect that the genocide that occurred was in fact wholly or partially prevented. It does not appear from the procedural documents or the arguments submitted that the Bosnian Serbs took UN resolutions seriously at those days. There is nothing to indicate that warnings (in addition to the general awareness of punishment of war crimes) could have had any positive effect in due time, whereas it has been established that awareness of the existence of 'Franken's list' did not stop the Bosnian Serbs from executing people. Furthermore, it has not been argued, nor is it plausible in light of the situation and the conduct of the Bosnian Serbs in the period around 13 July 1995 (relief convoys were stopped or only admitted piecemeal), that sufficient numbers of UN vehicles 
could have entered the area controlled by the Bosnian Serbs on time to help the population, UNPROFOR or the Bosnian men by means of observers or otherwise.

44.7 It follows from the above that even if failure to report war crimes from 8 July 1995 should be considered a wrongful act, contrary to SOP 208 and the Geneva Conventions, as the Association et al. argued in their explanation of ground 19, it has not been established that this would have led in due time to the kind of intervention that could realistically have saved lives.

44.8 In light of the above, grounds $30,31,34,35,43$, and 44 put forward by the Association et al. fail, and so do the arguments given in the explanations of grounds 11-15 and 19, containing observations of war crimes by Dutchbat and the reports thereof.

Evacuation, separating the men for screening for war crimes: not wrongful per se

45.1 It has been established that during the evacuation of the refugees the male refugees were separated and removed separately by the Bosnian Serbs. In order to assess the wrongfulness or otherwise of the acts performed by Dutchbat, the Court of Appeal, first and foremost, states as follows.

45.2 In principle, investigating whether people from a war zone where war crimes took place committed war crimes is permitted. Therefore, in principle, it is not wrongful to screen refugees for that purpose, for it could not be excluded that there were men amongst the refugees who had committed war crimes. Whether the men had already been disarmed when they were selected for screening is not relevant in that respect. Such a screening should however lead to (as the District Court found) either trial by court-martial of the people selected by the screening as suspects, or their release together with the other refugees, and people should be treated, during screening and further investigations, in accordance with the Geneva Conventions. In this case, the Court of Appeal also considers relevant that on 12 July 1995 the assumption was that war crimes had been committed (not just by Bosnian Serbs against Bosnian Muslims, but) also by Bosnian Muslims against Bosnian Serbs. This assumption has been established as fact (also) by (inter alios) the ICTY in the case against Krstić. In this light, the mere separation of the men - to screen them, according to the Bosnian Serbs - need not have aroused suspicion with Dutchbat.

45.3 The lists of male victims submitted on appeal by the Association et al. also contain the names of young children (such as a new born baby, a boy born in 1984 and other boys born after 1980). It has been insufficiently argued to establish that these boys were present in the mini safe area during the evacuation and were separated from the other refugees there. As the State pointed out, the locations where bodies were found in the woods indicate the contrary. Even if it had been found that they had been separated during the evacuation, the Court of Appeal could not establish who amongst them (particularly those born before circa 1982) could have been identified by outward appearance without screening that they could not have committed war crimes due to their age. All in all, it has been insufficiently substantiated that Dutchbat was involved in separating young male refugees about whom it was evident at first sight that they were too young to have committed war crimes. Ground 29 put forward by the Association et al. must fail in this respect.

Evacuation; first awareness of inhumane treatment and/or execution 
46. The Court of Appeal upholds the District Court's ruling that Dutchbat's facilitating the separation of the male refugees on their way to the buses was wrongful, in principle, if Dutchbat knew or should reasonably have understood that this separation was not for the purpose of screening them for war crimes, but to subject the separated men to an inhumane or humiliating treatment or even kill them. In so far as the Association et al. intended to refer to this as well in their ground 29, this will be assessed in light of the following grounds (particularly ground 42 put forward by the Association et al., and ground 4 put forward by the State.

47. Before addressing the question of Dutchbat's awareness of the fate of the men (in 49 below), the Court of Appeal will first (in 48.1-48.3) deal separately with the claim put forward by the Association et al. that Dutchbat started the evacuation.

48.1 In the opinion of the Court of Appeal, it cannot be alleged against Dutchbat that it allowed the refugees to be transported by Serbian buses instead of having them wait for transport arranged by the UN. Nothing has been argued from which the Court of Appeal could conclude that as early as 11 or 12 July 1995 transport was on its way from the UN to Potočari, or that there was a concrete prospect that this transport could get to the enclave sufficiently quickly. It has been established that UN convoys were no longer allowed through at the time, and that Mladic had said that he wanted to arrange transport for the evacuation himself. Evacuation without the consent of the Bosnian Serbs was only possible with NATO support and had to be carried out with helicopters. Time to prepare for this was three days (NIOD report p. 2298), leaving aside the fact that support would have to be raised within the international community (see also 44.2 and 44.4 above). For transport by Dutchbat itself there was not enough capacity and fuel. This is not outweighed by the assertion put forward by the Association et al. that Voorhoeve had indicated in 2015 that the UN could have arranged transport promptly, as UNPROFOR had ample transport capacity, as the Association et al. substantiated with a quote from De Groene Amsterdammer weekly. Leaving aside whether this assessment was correct, the issue is not what could have been achieved as far as transport capacity of the UN was concerned, with hindsight, but what at the time could have been implemented immediately, considering the capacity in the mini safe area.

48.2 In this respect, it is important that meanwhile the situation in the mini safe area was appalling. It was hot and there was little water. There was no prospect of improvement of the living conditions; Gobilliard's order of 11 July 1995 to "be prepared to receive and coordinate delivery of medical and other relief supplies to refugees" (see 2.45 above) and a letter of 12 July 1995 sent by Janvier to Mladić saying that the UN was capable of supplying provisions do not suffice, as it has been established that the UN relief convoys were, in fact, not allowed through. When the buses arrived, the refugees felt compelled to leave. A massive run on the buses ensued. This resulted in chaos, and there was a threat of refugees trampling each other. Dutchbat soldiers were pushed towards the buses by the masses (NIOD report p. 2646). The first buses departed overcrowded. Moreover, when the evacuation had started, the behaviour of the Bosnian Serbs changed. The situation that arose is captured by a quote from Lieutenant Mustert (NIOD report p. 2647, see also District Court judgment 4.214): 
"When the buses arrived, we just walked between them. If people did not respond quickly enough to signals given by the BSA [VRS] not to get on the bus, sometimes they were kicked or pushed, and we urged them to stop. After about an hour they were fed up with us and we were not allowed to get near the buses. You're with your back against the wall."

The Association et al. have insufficiently disputed this situation asserted by the State, and it is sufficiently supported by the procedural documents.

48.3 Considering all this, it certainly did not stand to reason to prevent the refugees to use the buses provided by the Bosnian Serbs, even if Dutchbat had known that the original plan was not to have the Bosnian Serbs arrange transport, but the UN. The available transport offered a way out of the worst misery. It has been established that the majority of the refugees (women, children, the elderly) were brought to safety by the evacuation.

49. Ground 32 put forward by the Association et al. is directed against the District Court's ruling that only from the late afternoon of 13 July 1995 Dutchbat had to take into account the serious risk of genocide. The Association et al. argued that Dutchbat should not have participated in the evacuation of the population because of its awareness of the risk of genocide. Ground 3 put forward by the State also pertains to the District Court's judgment on Dutchbat's awareness. Besides awareness of the risk of genocide, this ground also brings up for discussion the knowledge that the transported men ran a real risk of death or torture or inhumane and degrading treatment. The Court of Appeal will now discuss these grounds together.

50.1 With respect to genocide, the Court of Appeal refers to what was considered under $34.1 \mathrm{ff}$. above. With regard to the above grounds, the Court of Appeal will deliver judgment on the question about the (first) awareness that the evacuated men, besides genocide, ran the real risk of deprivation of life or being subjected to torture or inhumane or degrading treatment (hereinafter succinctly referred to as 'inhumane treatment'). For facilitating the evacuation or separating the men to be a wrongful act it is not required that there was awareness of genocide; awareness of a real risk of violation of the fundamental human rights laid down in Articles 2 and 3 ECHR and 6 and 7 ICCPR has the same legal consequences. For this reason, to allow the claims of wrongful conduct put forward by the Association et al. it is not required that knowledge existed of the impending genocide by Bosnian Serbs during the evacuation. The absence of concrete knowledge, asserted by the State, that the men were headed towards a certain death is too strict a standard for determining wrongful conduct. Ground 3 put forward by the State is dismissed in this respect. The Court of Appeal will not take genocide into consideration in this connection, therefore.

50.2 In this case, in which the acts and omissions of Dutchbat (the State) are under discussion, it is important that the asserted knowledge should have been present in the minds of those who were competent to take (some) decisions with regard to those acts and omissions, particularly about the evacuation and its supervision. The fact that individual soldiers observe war crimes is not (per se) sufficient according to generally accepted standards to assume knowledge and therefore a wrongful act on the part of Dutchbat (the State). In this connection, the 
Court of Appeal has not just considered that these soldiers were not allowed to take decisions (due to their position), but also the nature and circumstances in which this knowledge must have existed, namely: in a brief, chaotic two-day period, while thousands of people ware awaiting evacuation in appalling circumstances, while understaffing occurred, and shortly after Dutchbat had had to give up its UN peacekeeping mission.

50.3 The Association et al. argued that knowledge of individual Dutchbat soldiers must be considered to be knowledge of those in charge, because the State is liable for the faults of its subordinates pursuant to Article 6:170 DCC, such as failing to report war crimes. This argument does not succeed for the sole reason that it has been insufficiently argued that this failure to report (during the evacuation, so before the debriefings which did not take place until later) was attributable to the subordinates themselves.

50.4 Ground 3 put forward by the State, asserting (inter alia) that those in charge need to be aware of the knowledge, succeeds in this respect. It must be established whether the officers in charge of Dutchbat had knowledge, during the evacuation, of the fate awaiting the separated men. In this context, the meaning of 'the officers in charge' includes anyone who could take a relevant decision with regard to the men. Therefore, this is not limited to the officers in charge in the UNPROFOR headquarters or in the council of ministers, but includes the commanders giving orders in the mini safe area (including Franken and Karremans).

51.1 With regard to the (first) awareness of Dutchbat of the real risk run by the men of being subjected to torture or inhumane or degrading treatment or deprivation of life, the Court of Appeal considers as follows.

51.2 From the messages Dutchbat originally received about the evacuation it could not be inferred that anything went wrong with the evacuation. The Bosnian Serbs took the people to sheltered accommodation set up for the population, as had been agreed by and as was the intention of the UN and the State. In this connection, the Court of Appeal refers to the substance of Franken's statement before the Parliamentary Committee of Inquiry (PCI interviews), p. 76):

"At first, things seemed to be all right. According to reports I received from the North East section and from the Pakistani battalion which held that part of the CL in the Tuzla area, large numbers of people came in without too many problems, and initially there were even men amongst them."

In the beginning, nothing seemed to go wrong with the men who had been separated for screening. Van Duijn stated about this to the Parliamentary Committee of Inquiry (PCI interviews, p. 30):

"At one point we noticed (...) that men were singled out from amongst them by the Serbs. (...). [question: Did you pass this on, that you saw men being singled out?] Yes (...) I was asked if I could still see them, and I could answer that this was the case, because they were seated on a lawn in front of a house."

51.3 Gradually, however, during the evacuation, it became known to the officers in charge of Dutchbat as well that the men ran a real risk due to evacuation of being exposed to inhumane treatment and execution. The Court of Appeal bases this on the following grounds $(51.4 \mathrm{a}-\mathrm{f})$

51.4a The above statement by Van Duijn continued as follows: 
“(...) It was not until late that evening that the men were taken away from there by lorry.'

51.4b The NIOD report reads, pp. 2651 and 2652:

"On the way hardly any problems had presented themselves, and the men who had managed to get on the first buses appeared to have arrived safely, according to the Pakistani battalion. (...) The next convoys that had departed did get in trouble on the way. (...) Besides, there was no clear picture in Potočari of the situation at the destination, particularly of the fact that the refugees had to cover a considerable distance on foot (...). With regard to this, Franken stated later: “(...) We then tried to get the injured out as well as soon as we could. I saw an opening to get those people out safely. You never knew with those Serbs how things might change." This prompted Franken to send the convoy with 54 casualties off as soon as possible in spite of the late hour - it was almost six o'clock and dusk would soon set in. (...) It was well after midnight that the convoy arrived in Tišća; and there only a limited number of casualties were allowed to cross the border. Men who pretended to be injured (...) were taken away by the VRS."

51.4c Franken stated about this to the Parliamentary Committee of Inquiry (PCI interviews, p. 76):

"The trigger to stop the evacuation did not present itself until later, really. (...) When the situation at the white house deteriorated - I am referring to the way in which the Serbs treated the men - that could have been a trigger to stop the evacuation. We [the Court of Appeal understands: the officers in charge] did consider whether it was time to stop. We then decided explicitly and clearly in favour of the large numbers of women and children. If I discontinued the evacuation, (...) a situation would have developed with many fatalities without Mladic having a direct hand in it. Mladic had (...) time (...) on his side in that respect. I started to suspect that things were looking more grim for the men than one could have imagined before. Considering everything, I decided, or at least advised, to continue the evacuation, and not to stop for that reason. It meant one made a conscious decision: I decided in favour of the 25,000 women and children at the cost of perhaps - it was not clear to us that all the men were going to be slaughtered - those 600 to 700 men. (...)”

and went on to say (PCI interviews, p. 77):

[inquirer: "According to the NIOD you had doubts about the fate of the ablebodied men in the enclave as early as 12 July (...)." Franken:] "From the first reports that people were beaten, I sent the UNMOs -who were with us-over there (...) I received reports that they were under the impression that it had subsided a little due to their presence, but that overall a fair degree of violence was resorted to. The number of reports increased. Then you start considering: Am I going to do something about it? It was possible to seize that house in a very quick raid, get the men out and bring them back to one's base. But I was faced with the same situation that I depicted before with regard to whether to stop the deportation. [inquirer: Again, you were faced with balancing the interests of a number of men against those of thousands of refugees? (...); Franken:] "Yes (...).

When I was thinking about how I could offer some protection to the men (...) [I] tried to register all men (...). It was my intention to publish that list (...) to put 
some pressure on the Serbs: Watch it, we know exactly who were taken, and we can monitor and follow them. (...) at that point at was the only form of protection I could still come up with, because we had decided in favour of the women and children before. (...) I told the Serbs I had registered the men. (...) But they did not appear to be impressed."

Franken also stated before the ICTY (statement of appeal submitted by the Association et al. no. 404):

"The trigger for me [Court of Appeal: to make a list] was the increasing violence in the interrogation of the men. So I already stated that I had the feeling in the late afternoon of the 12th that we were not in control in any way anymore, and that triggered me for this solution."

51.4d Rutten stated to the Parliamentary Committee of Inquiry (PCI interviews, pp. 46 and 47):

"That morning [Court of Appeal: Thursday, 13 July 1995] (...) we received information: a number of buses was departing in the direction of Bratunac. Those buses were followed by a lieutenant of the Korps Commandotroepen (KCT) and a driver. This all-terrain vehicle that followed them was stopped near Bratunac; the buses drove on. We heard that the lieutenant was stopped and threatened. He was made to surrender his all-terrain vehicle. Then it was evident that the men would meet "another fate". Those were the men who had been assembled the previous day in those houses. (...)

I assume that he [Court of Appeal: the company commander] reported this to the battalion, because shortly thereafter I was requested to participate in escorting the convoys as well. One may infer from it that the battalion understood that further monitoring of the buses was of some significance. (...)

[in the morning of 13 July 1995:] I was together with a company sergeant-major. He came along to the so-called White House. We found out that certain things were going on there, interrogations etc. (...). Upon approaching the house we crossed the garden and saw stacks of ID documents, passports, work cards etc. Next, we saw piles of clothes lying about. We arrived at the house; (...). There were also two KCT soldiers who had been posted there by a colleague to oversee to some extent what was going on. (...) Then we saw that a Muslim man was strung from the stairs in such a way that his feet just did not touch the floor. (...) Next, I tried to enter a room in front of which a Serb soldier was posted. This was prevented by pushing a gun in my face. Apparently, it was the interrogation room. (...) I tried to see what was upstairs. Mainly men, older men and younger boys, adolescents. (...) Indescribable... I said earlier, in a statement, that one can smell death. (...) It is really true. (...) After I had taken the pictures (...) I went back to the road and things were reported to lieutenant-colonel Karremans, who was by the roadside as well."

$51.4 \mathrm{e}$ As a witness testifying in a provisional witness examination, Oosterveen stated to the District Court:

[Question: You stated to the Rotterdams Dagblad newspaper (17-08-1995): “We heard shots fired from time to time. Not rattling gunfire as in combat, but shots fired at intervals. To execute people." Whom did you refer to by "we"? When did you hear that?] 
We: were the personnel that were in the compound in the evening and during the night. They weren't ordinary sounds. This was on 12 or 13 July, (...). [Question: Did you report this? (...)] No, there was no need. Everyone could hear them."

51.4f After the evacuation had been stopped by the late afternoon of 12 July 1995, a representative of the refugees spoke with Franken. He asked Franken to end the evacuation because there were signs that the refugees were not safe in the hands of the Bosnian Serbs. Franken then consulted with Karremans about ending the evacuation.

51.5 In the opinion of the Court of Appeal it follows from this, and from the substance of the statements referred to above by Franken, Rutten, and Oosterveen, that the officers in charge of Dutchbat (of whom Franken was one) as early as the evening of 12 July 1995, so during the evacuation, became aware of 'the treatment of the men by the Serbs.' Although this treatment as occurring before 13 July 1995 has only been specified in statements in respect of one man (who was strung up from the stairs), besides reports of the 'fair degree of violence that was resorted to', the Court of Appeal rules on the basis of everything considered above (as did the District Court in 4.247 and 4.248), that in the evening of 12 July 1995, the officers in charge were aware that the separated men were not just selected for screening for war crimes in the manner described under 45.2 , but that they ran the real risk of being subjected to torture or inhumane or degrading treatment, or of being executed. The Court of Appeal also considers the following facts in this respect:

- Franken sent UNMOs (United Nations Military Observers) to the White House, from whom he received reports (presumably: at least at the end of the day); in the White House Rutten did find soldiers of the Korps Commandotroepen,

- Dutchbat considered to liberate the men from the White House with a quick military raid and to end the evacuation, and then made a 'conscious decision' in favour of the women and children,

- Franken drafted a list,

- execution shots were heard that were audible to anyone (so including to the officers in charge).

Besides, as early as in the morning of 13 July 1995 Karremans (and later also Nicolai) was (resp. were) aware of the find of nine bodies of executed men (see 2.55 above), and an observation of an execution witnessed by private Groenewegen was passed on to the officers in charge of Dutchbat.

51.6 Considering all this, the Court of Appeal dismisses ground 3 put forward by the State in as far as it is directed against the District Court judgment that Dutchbat knew on 13 July 1995 that the men, if they were separated and deported by the Bosnian Serbs, ran a real risk of deprivation of life or inhumane treatment (District Court judgment, 4.245-4.254). The Court of Appeal will leave unanswered whether Dutchbat should have been aware that day of the serious risk of genocide committed by the Bosnian Serbs, as found by the District Court (District Court judgment 4.255-4.257). As the Court of Appeal considered above (see 50.1), this is irrelevant for the claims of wrongful act. (With respect to the independent claim of genocide the Court of Appeal ruled already in ground 34 that it must be dismissed in these proceedings). 
52.1 To rule that Dutchbat must have known before the evening of 12 July 1995 that the separated men ran a real risk of deprivation of life or torture or an inhumane or degrading treatment, the Court of Appeal has insufficient grounds. Besides the considerations referred to in 51.2, the Court of Appeal finds as follows in this respect.

52.2 What is relevant is the knowledge that a real risk existed after the area had been occupied and after the negotiations with Mladic in which it had been agreed that the rounded-up population was allowed to be taken from the area to a location set up as shelter location by the UN. The issue is not the risk the men ran during the occupation or the risk they would run if they stayed in the area occupied by the Bosnian Serbs, but the risk they ran if they were taken to a shelter location outside the enclave by the Bosnian Serbs on 12 or 13 July 1995.

52.3 The circumstance that murders had been committed by the Bosnian Serbs and that the lives of Bosnian Muslims had been feared for prior to 12 July 1995 does not mean that Dutchbat should therefore have taken into consideration the risk of executions or exposure to inhumane treatment during an evacuation to a location outside the enclave to which the Bosnian Serbs had agreed. 'Ethnic cleansing' of the area by the Bosnian Serbs had already occurred when the population was driven off towards the mini safe area; there was nothing to indicate that the Bosnian Serbs intended a second 'ethnic cleansing' in the area. The genocide that was ascertained later dates from after 13 July 1995.

52.4 After the negotiations between Mladić and Karremans, Dutchbat could assume, in principle, that the entire rounded up population would be brought to safety, because the Bosnian Serbs had consented to the evacuation of all Bosnian Muslims. The refugees on the first buses did in fact get to Tuzla, including the men (see 51.2 above).

52.5 The Association et al. argue that a sequence from NRCV Netwerk [a TV current affairs programme] broadcast on 27 March 2002 shows that the in the council of ministers the concrete fear that the men would be killed was expressed. The Court of Appeal has watched and listened to this sequence that was submitted by the Association et al. The fragment shows the following:

"Minister Sorgdrager asks what response there will be if the other enclaves fall as well. The question is where the refugees will be put up, and what role will still be reserved for UNPROFOR. She wonders if there are any Dutch citizens in the other enclaves. Minister Voorhoeve answers in the negative.

The prime-minister believes that first of all a solution must be found for the most urgent issue, namely how the people can be brought to safety. He asks what should be done if the Bosnian Serbs do not give permission to leave.

Minister Voorhoeve answers that the prime fear is that all male Bosnian Muslims will be killed. In his interview with the Bosnian minister of foreign affairs Sacirbey it was evident that the latter shared this fear."

This sequence does not pertain to the situation in which the Bosnian Serbs did give permission to leave. It concerns the council of ministers meeting of 11 July 19957.30 p.m. (NIOD report pp. 2297 and 2298), so before the evacuation of the refugees from the enclave was allowed by the Bosnian Serbs (during the negotiations between Karremans and Mladić) and before the UN had a shelter 
location for them in a safe area. The minutes report the fear that the Bosnian Serbs would not give permission for the evacuation of the refugees. The same applies to the concern expressed by Van Mierlo, put forward by the Association et al. (statement of appeal of the Association et al., no. 387). In the council of ministers meeting the following comment was made (statement of appeal of the Association et al., no. 386):

"Most urgently required was finding a safe haven, because the situation that had arisen would undoubtedly lead to ethnic cleansing."

It has been established that subsequently permission was given for evacuation, including the Bosnian Muslims, and that a location for a safe haven was found. The same applies to previous council of minister meetings (of which no minutes are available).

52.6 The Association et al. further pointed to the statement Franken made before the ICTY. The Court of Appeal rules that based on this statement it cannot be established that Dutchbat was aware of the treatment awaiting Muslim men in this evacuation prior to it. The statement reads:

In answer to the question what the reason was for the bombings: "killing people or trying to raise a panic by killing people. And I mean by 'people', I mean civilians, women and children"

following which Judge Riad went onto say (inter alia) (in connection with the question what Franken expected if the Bosnian Serbs carried out the evacuation themselves): "I put this in connection with other affirmations which you said. You said (...): "I expected the Serb forces to start killing civilians indiscriminately" (...) "that would be delivering the Srebrenican people to their butchers (...).", to which Franken responded: "That is correct sir. I had those fears."

In this statement Franken indicates that the Bosnian Serbs would kill everyone in the event of bombings and evacuation. In Franken's statements there is no indication that he expected such a massacre in case of an evacuation to which the Bosnian Serbs had consented following negotiations with Mladić; on the contrary, Franken stated (elsewhere) that he believed this evacuation was intended to bring people to safety ('If I stopped the evacuation, (...) a situation would arise with many fatalities' - see 51.4c above). The Court of Appeal also points out that because of this evacuation right in front of the Bosnian Serbs, thousands of people were in fact brought to safety.

52.7 The Court of Appeal finds that Dutchbat (the State) did not know until nor any later than the evening of 12 July 1995 that the separated men ran a real risk of being subjected to torture or an inhumane or degrading treatment, or of being executed. In so far as the Association et al. in their ground 32 and the State in its ground 3 argued otherwise, these grounds are dismissed as unfounded.

Not admitting the population to the compound in second instance: non wrongful act.

53.1 Ground 38 of the Association et al. is directed against the judgment that Dutchbat could not admit all refugees, or at least the group of men and boys who ran the gravest risk, to the UN compound (District Court judgment, 4.284-4.291).

53.2 The circumstances in which the refugees would have found themselves in the compound were appalling in the days from 11 July 1995. There were not enough 
sanitary facilities in the compound for the large number of people present. It was hot and there was little water and food. Franken stated before the Parliamentary Committee of Inquiry that people who had died "of exhaustion et cetera" were buried in the compound (PCI interviews p. 73). The Association et al. have acknowledged that in the compound, too, the refugees were often deprived of food and water. Restocking the supplies was impossible as the UN relief convoys were stopped by the Bosnian Serb military. The first UNHCR convoy was not admitted until the afternoon of 13 July 1995, after the evacuation had been completed with the exception of the injured and Dutchbat (personnel) (PCI end report p. 233, NIOD report p. 2728). Circumstances in the mini safe area deteriorated visibly on 12 and 13 July 1995.

53.3 About the situation on 11 July 1995, Franken stated before the Parliamentary Committee of Inquiry (PCI interviews pp. 73 and 74):

"We were confronted with particularly high temperatures. There was little or no water. The local water supply system was not in working order at all, and what we had ourselves we needed to purify via clever machines. (...) What they yielded was completely disproportionate to the water needs of some 30,000 people. (...) People started dying. According to my information we could hold out for four days, give or take one day, depending on the weather.

[Question: Does that mean you would have enough water for four days? Franken:] No, it meant that we had to establish priorities with regard to whom we supplied water to, for instance to the huge numbers of young children amongst the crowds. We had to reserve water for our infirmary for patients who had come in with symptoms of dehydration, but that was it.

[Question: What about the food supplies? Franken:] At one point we just lumped together everything we had (...). It was absolutely insufficient (...)

[Question: Can you tell us something about hygiene in the compound? Franken:] I can. There was no hygiene. (...) People panicked so much that they just defecated in the hall. (...) If that's the case when 5,000 people are huddled together in a bare concrete hall at temperatures of 30 degrees Centigrade, I am sure you get the picture. We had no water for them to wash themselves. (...) People just sat in that mess impassively, and there were women giving birth (...)

[Question: What action did you or lieutenant-colonel Karremans undertake to get international organisations in, such as the Red Cross? Franken:] The first thing he did, almost immediately after the first negotiations with Mladic, was sketch this situation and ask for support or permission that food and such like were delivered. That did not happen; it was not allowed by the Serbs. (...) It was evident that the UNHCR attempted to get inside the enclave with food (....)

[Question: What has become of their attempts in actual fact?] Nothing, because it just was not allowed and it did not get through. (...) At that stage, smugglers did not get through anymore, either. Let that be clear."

53.4 Furthermore, Franken stated about the decision taken in the evening of 12 July 1995 (PCI interviews p. 76):

"If I stopped the evacuation, Mladic need not be upset really, because the problem would then solve itself within days. This sounds very cynical, but then a 
situation would have developed with many fatalities without Mladic having a direct hand in it."

In light of the context of this statement, it is clear that Franken meant that all refugees would have died then of dehydration or exhaustion within a matter of days.

53.5 Against the substance of the above statements insufficient evidence has been adduced in rebuttal. In connection with the timespan referred to in 53.3 (four days, give or take one, depending on the weather) the Court of Appeal notes that weather conditions did not improve on 12 and 13 July 1995 (conditions remained hot and arid).

53.7 Dutchbat (the State) could assume that it was impossible to receive everyone until UN relief would reach the mini safe area, because the relief was not allowed to pass through (see 48.1 above). There was no prospect of timely deliverance by the $\mathrm{UN}$, therefore.

53.8 In view of all the above considerations, Dutchbat did not need to recede from the earlier resolution adopted by the UN to receive only 5,000 refugees in the compound. The Court of Appeal rules, as did the District Court (in 4.289), that admitting all refugees to the compound instead of evacuating them was not a realistic option. That the area of the compound as far as size was concerned could possibly have accommodated tens of thousands of people, is not sufficient for adequate shelter to be realised. This is not changed by the fact that Dutchbat personnel managed to survive after 13 July 1995, for after the evacuation of the refugees the UN were allowed to pass through to the compound with relief supplies again (as opposed to before). The Court of Appeal also finds the 'calculation' made by the Association et al. that half the people could have survived twice as long (statement of appeal under no. 180) insufficient to assume that all people present in the compound had a chance of survival, due to appalling sanitary circumstances, the heat and the fact that there was little food and water available. In ordinary circumstances people can only hold out for a couple of days. Nothing has been argued to show that thousands of people would have held out significantly longer. Ground 38 put forward by the Association et al. must fail in this respect.

Not admitting the men and the boys in the mini safe area to the compound in second instance: no wrongful act.

54.1 With regard to the question whether Dutchbat should at least have admitted to and given shelter in the compound the men and boys who were in the mini safe area in the evening of 12 July 1995, the Court of Appeal considers as follows.

54.2 The Association et al. argued that there were approximately 700 underage boys in the mini safe area. In 42.1 and 42.2 above, the Court of Appeal indicated that there were hundreds or even thousands of men in the mini safe area at the start of the evacuation. Part of them had already left on 12 July 1995. It must be taken into account (in light of, inter alia, what the Association et al. asserted) that at least approximately 1,000 men were still present in the evening of 12 July 1995 . The Court of Appeal does not believe it is realistic to assume that Dutchbat could have received and kept alive such a large number of men in the compound at the time together with the refugees already present there. The Court of Appeal considers as follows in this respect (54.3a-e). 
54.3a A few days before, Dutchbat had been informed that the VRS did not want to allow any refugees in the compound, because the VRS could not distinguish between refugees and fighters (NIOD report p. 2604). Next, it had been decided (still within the UN, see 27.2 above) to admit the refugees to the compound through a hole in the fence and to give them shelter in the vehicle halls - out of sight, therefore, of the Bosnian Serbs (NIOD report p. 2606).

$54.3 \mathrm{~b}$ If Dutchbat had selected the male refugees from the other refugees in the mini safe area and transferred them to the compound, this would have been noticed by the Bosnian Serbs. Even if the population had cooperated in the separation of the men and boys from their midst quietly (which the State contested, stating reasons), the relocation of so many male refugees to the compound would have been discovered, even if this would have been done in the morning of 13 July 1995 before the Bosnian Serb soldiers arrived to continue the evacuation - leaving aside the question whether this had been possible), for there were Bosnian Serbs present amongst the population (considering the war crimes commited in the night of 12 to 13 July 1995, and the statements made by the appellants, submitted as exhibits to the writ of summons in first instance).

54.3c Although the Bosnian Serbs did not get inside the fences, they had control outside and at the gate. They had the entrance gate to the compound (literally) in their sights (statement of appeal put forward by the State no. 4.2.9 and NIOD report p. 2603), and they had a view of the fences.

54.3d The Bosnian Serbs found it important to get their hands on the male refugees, initially for screening purposes, as they put it. To get them they did not just separate the male refugees from the other refugees when they headed for the buses, but they also got them off the buses and off a convoy of injured refugees later (see 51.4b above), even outside the enclave at the border near Tišča. It would be unrealistic to expect that the Bosnian Serbs would have allowed approximately 1,000 men to take cover together with Dutchbat in the compound undisturbedly, for the Bosnian Serbs believed that these men were (at least in large part) enemy fighters of AHiB. Dutchbat could not assume, therefore, that the Bosnian Serbs would have allowed hundreds of Bosnian Muslim men to enter the gates of the compound undisturbedly and to stay there, but had to take into account the serious risk of a massacre (see below 54.3e).

54.3e Dutchbat was aware that before the evacuation, Bosnian Serbs had not hesitated to rout and fire at the Bosnian Muslim population. The Bosnian Serb guns and mortars could easily cause a carnage among the refugees. For the sole reason that there were still thousands of refugees in the compound, Dutchbat could not run the risk of the compound being shelled by the Bosnian Serbs. It may be true that the Bosnian Serbs did not constitute (or no longer constituted) a threat to the refugees in the sense of deploying their weapons systems, as the Association et al. argued, but Dutchbat could assume that the weapons would be deployed, or at least that there was a serious risk, as soon as some thousand men would settle in with Dutchbat without the permission of the Bosnian Serbs.

54.4 The conclusion is that if the men had been selected from the other refugees in the mini safe area and taken to the compound in plain view of the Bosnian Serbs, the lives of tens of thousands of people would have been put at stake. The Court of 
Appeal rules, as did the District Court (in 4.291), that not admitting all male refugees to the compound in second instance does not constitute a wrongful act. Ground 38 put forward by the Association et al. is dismissed as unfounded.

55. Ground 40 put forward by the Association et al. is directed against the District Court judgment that Dutchbat only wanted to assist in the smooth running of the evacuation (District Court judgment, in 4.296-4.298), and alleges against the District Court that it disregarded the fact that (1) the appalling circumstances and the wish of (large numbers of) the population to leave the enclave arose from the fact that Dutchbat did not protect the population and did not take robust action against the Bosnian Serbs, and that (2) Dutchbat, on the State's orders, initiated the evacuation of the refugees and subsequently left the implementation in the hands of the Bosnian Serbs. This ground for appeal progresses from what the Association et al. asserted before and what was already dismissed before. For this reason, the ground does not succeed.

56. Ground 41 put forward by the Association et al. is directed against the District Court's ruling that Dutchbat did not have to stop the evacuation in the evening of 12 July 1995. This ground also follows on from what was asserted before, and is also dismissed as unfounded, therefore. The Court of Appeal notes again that it does not share the view of Association et al. that according to the ICTY the population was no longer at risk. As considered above under 43, the argument put forward by the Association et al. by reference to the opinion of the ICTY, quoted before, about the lack of need for the Bosnian Serbs to evacuate the population, must fail. The fact that the Bosnian Serbs lacked the need because they could have improved the living circumstances of the population, does not mean that Dutchbat lacked this need because Dutchbat could have effected this improvement as well. It was the Bosnian Serbs (not Dutchbat) who prevented the UN relief convoys to pass through and whose (criminal) acts threatened the population.

Continued supervision of the evacuation from the mini safe area on 13 July 1995 before the arrival of the Bosnian Serb troops: no wrongful act

57. Ground 42 of the Association et al. is directed against the District Court's considerations with regard to the continued supervision of the evacuation on 13 July 1995 (District Court judgement, in 4.304-4.311). The Association et al. believe that Dutchbat should have stopped the evacuation on 13 July 1995, and that their continued supervision of the evacuation on 13 July 1995 constitutes a wrongful act, also in the absence of an alternative. The State refutes that the evacuation should have been stopped and that supervision constitutes a wrongful act, and the State also challenged that Dutchbat actively cooperated in separating the men.

58. The Court of Appeal states first and foremost - and this is not in dispute between the parties - that separating the men for the purpose of subjecting them (or being able to subject them) to torture or inhumane or degrading treatment and executing (or being able to execute) them, is wrongful.

59. The Court of Appeal finds, on the same grounds as the District Court, that Dutchbat could not be expected to stop and prevent the continued evacuation on 13 July 1995 (District Court judgment in 4.303; put succinctly: there was no alternative for bringing the other refugees to safety from the increasingly untenable situation in the mini safe area, they did not run the risk of being deprived of their life or being 
subjected to inhumane or degrading treatment but were taken to Kladanj as had been agreed, continuation of the evacuation was in their interest). In this respect, the Court of Appeal also refers to what is considered under $53.2 \mathrm{ff}$. above. On 13 July 1995, the situation had deteriorated even further, there was no (prospect of) UN relief, refugees had been terrorised by Bosnian Serbs (again) in the night of 12 to 13 July 1995 (see, inter alia, the statements made and submitted by the appellants quoted before) and (large numbers) of the population wanted (out of necessity) to leave the enclave. Considering the living conditions at that moment in the mini safe area, which the Court of Appeal has described above (inter alia in 53.2), thousands of people were at risk of losing their lives if the evacuation was stopped and they had had to stay in the mini safe area. Continuing the evacuation of the population (or having it continued) after it became known what could happen to the men, was not a wrongful act, therefore.

60.1 When in the morning of 13 July 1995 the buses appeared before the Bosnian Serb soldiers who were involved in the evacuation did, Dutchbat started to escort the refugees, including the men, to the buses. This went on for over an hour (NIOD report p. 2739). The first buses left without the presence of the Bosnian Serb soldiers. There are no indications (not in the appellants' statements, either) that Dutchbat separated male refugees from the smaller groups of refugees on their way to the buses, or had them separated. These first buses took both women and men. Van Duijn stated about these early hours to the Parliamentary Committee of Inquiry (PCI interviews, p. 32):

"At that point I thought: (...) This way we can let them board the buses in a humane manner, without the Serb soldiers interfering or pulling men out."

The claim of the Association et al. in their Statement of Appeal (in no. 506) that in the absence of the Bosnian Serbs, Dutchbat separated men and boys from the other refugees, knowing their fate, is not supported by any document and is therefore insufficiently substantiated.

60.2 According to the NIOD report (pp. 2739 and 2740) Bosnian Serbs forced buses that had left early to stop at a roadblock and pulled off large numbers of men, so that the early start probably saved the lives of only a handful of men, in the end. According to the Association et al. (in their explanation of ground 42, statement of appeal no. 504) this concerns only two men. Notwithstanding this, the Court of Appeal cannot establish on the basis of this that it constitutes a wrongful act on the part of Dutchbat (the State). Dutchbat let the men travel by bus to the UN shelter location, and in light of what was considered above (see 54.4) Dutchbat cannot be found to have committed a wrongful act by continuing the evacuation without separating the male refugees and withholding them.

60.3 The Association et al. subsequently argued that Dutchbat should have chosen to have only men (as many as possible) depart on the first buses (in their explanation of ground 42, statement of appeal no. 508). The Court of Appeal dismisses this alternative. In that case, Dutchbat would have had to separate the men from the other refugees themselves, while all refugees - including the women, children and the elderly - were in the mini safe area in appalling conditions and had to leave the place as soon as possible. Moreover, Dutchbat could not reasonably 
expect that buses full of (only) men would be allowed to be pass through by Serb posts on their way to a UN facility.

60.4 In view of the above, in the situation in which Dutchbat and the population found themselves on 13 July 1995, Dutchbat (the State) could continue the evacuation independently before the arrival of the Serb soldiers, and have the men leave among the other refugees. There was no question of committing a wrongful act on the part of Dutchbat at this stage.

Continued supervision of the evacuation from the mini safe area on 13 July 1995 after the arrival of the Bosnian Serb troops: wrongful act

61.1 When the Bosnian Serb soldiers had arrived on 13 July 1995, the evacuation was continued. The male refugees were separated. About the way in which the men were separated on 13 July 1995 before refugees boarded the buses, the following has been established (see also NIOD report p. 2649).

-a- The uncontrolled flow of refugees to the buses was prevented by four YPR armoured tracked vehicles parked near there, tape and human chains of Dutchbat soldiers holding hands, which together was referred to as 'the corridor' (see 2.50 above). -b- In an adjacent plot, Dutchbat put together groups of (approximately) 60 to 70 refugees (of both women and men). People were admitted through the corridor in groups. -c- This way, the refugees walked in line to the buses for a short distance. Along this route, the VRS soldiers had a clear view of the refugees, and could readily distinguish the male refugees from the rest. As they were walking to the buses this way, the male refugees were singled out and separated from the women, children and the elderly before they arrived at the buses.

61.2 According to some of the appellants' statements, submitted with the writ of summons in first instance, Dutchbat soldiers stood holding hands with Bosnian Serbs. The Court of Appeal understands that in the human chains of Dutchbat soldiers there were possibly also Bosnian Serbs. The question whether this was true (in each instance) can remain unanswered. Relevant is that a human chain of (inter alios) Dutchbat soldiers essentially formed a wall, which together with the vehicles prevented effectively that refugees reached the buses without passing through the corridor.

61.3 The Court of Appeal will not make a decision on whether Dutchbat soldiers singled out and separated men from the other refugees themselves. According to some appellants, this did occur, but according to others and according to statements made before the Parliamentary Committee of Inquiry this is what the Bosnian Serbs did while Dutchbat soldiers only looked on. It has been established that because Duchbat put together groups of refugees in the way described in 61.1 above and had them walk to the buses through the corridor shaped by their human chain, the Bosnian Serbs could spot the male refugees and separate them from the other refugees more readily. In other words: the way in which Dutchbat supervised the evacuation actually facilitated the separation of the male refugees.

61.4 The Court of Appeal finds that the evacuation of the population could have continued without Dutchbat facilitating the separation of the men as a result of the way it supervised the process as described above, for if Dutchbat had stopped putting together groups of refugees and forming a human corridor, the population would have gone to the buses independently and voluntarily (though forced by 
necessity). This follows from the fact that (whenever supervision stopped) a run on the buses ensued. The refugees would then have got to the buses around the vehicles and through the tape, in conformity with Karremans' statement before the Parliamentary Committee of Inquiry (PCI interviews, pp. 332 and 333). That ending the putting together of groups and forming a corridor would have led to the complete discontinuation or prevention of the evacuation of the population has not been argued. There is nothing to indicate this following the incident whereby a Dutchbat soldier caused the evacuation to be halted for an hour and a half. It emerges from the NIOD report (p. 2740) that the latter was not because Dutchbat ended its cooperation in supervising the process, but because a Dutchbat soldier accused a VRS officer of fascism and this officer demanded an explanation.

61.5 The Court of Appeal rules, therefore, that Dutchbat (the State) could have ended the assistance to the evacuation it had rendered until then. It also should have ended it from 13 July 1995, when Dutchbat was aware that the Bosnian Serbs used the separation to be able to subject the male refugees to degrading or inhumane treatment or to execute them. From that moment on, Dutchbat should have refrained from actively taking any action that facilitated the separation of the male refugees, as a result of which very serious human rights violations could take place. As a result of this separation the men were exposed to the real risk of a breach of the fundamental rights guaranteed in Articles 2 and 3 ECHR and 6 and 7 ICCPR, as Dutchbat (the State) knew on 13 July 1995, or at least should have known.

61.6 In this connection, the Court of Appeal considered the very complex circumstances known from the procedural documents and put forward by the State (referred to above in, inter alia, 53.2 and 54.3e) in which Dutchbat had to operate, and in which it made the decision to continue its supervision of the evacuation by putting together groups and forming a corridor. Both the Association et al. and the State pointed out in this connection that Dutchbat, by supervising the evacuation, wanted to prevent that people collapsed, were trampled on or crushed each other. The interests of the women, children and the elderly depended on their supervision, according to the State. In this respect, the Court of Appeal considers as follows (ad):

-a- The Court of Appeal deems plausible (in view of what has been put forward and insufficiently disputed) that if supervision had been ended chaos would have ensued. When on 12 July 1995 there were no supervision and no corridor yet, a run on the buses and chaos had ensued, during which people were crushed and threatened to be trampled on, and buses left overcrowded. On 13 July 1995 there were still many thousands of people huddled together in the mini safe area who (out of necessity) wanted to leave. It is common knowledge, and it was demonstrated on the spot on 12 July 1995, that the departure of so many people results in chaos in the absence of proper supervision. The NIOD reported about this as follows (NIOD report, p. 2741):

"When the remaining refugees had to leave the compound in the afternoon of 13 July 1995, it threatened to end in chaos. A walkway had been cordoned off with tape running from the vehicle hall to the entrance gate to the compound. At the start it seemed that a run on the buses would ensue, as a result of which the elderly and children ran the risk of being trampled. The only option to prevent this was to 
structure the evacuation, and in the mean time to take care of those waiting in the scorching heat as well as possible."

-b- Based on the above, the Court of Appeal also considers it likely that if the people had not been directed to the buses through the corridor in groups, just like at the start of the evacuation on 12 July 1995 when there was no supervision yet, chaotic flocks of people would have ended up at the buses attempting to board them, pushing and too many at once, which buses would then have had to leave overcrowded. The Court of Appeal cannot establish, however, that people would indeed have been trampled or crushed. The Association et al. contested that this would have happened, and the State did not argue, nor was mentioned in the statements, that this had in fact happened on 12 July 1995, or why this would have happened on 13 July 1995.

-c- The Court of Appeal also considers likely, in view of what has been argued and insufficiently disputed, that the Bosnian Serbs would have treated people brutally if there had not been any Dutchbat soldiers between them and the population. In this respect, the Court of Appeal attaches value to what Franken stated about this before the Parliamentary Committee of Inquiry (PCI interviews, p. 75):

“(...) the Serbs used considerable physical force, against women and children as well, in order to cram buses suitable for 40-50 people with double those numbers.

and to what van Duijn stated about this to the Parliamentary Committee of Inquiry (PCI interviews, p. 32):

"The first day of the evacuation you saw families being torn apart, the separation of the men from the women and children. (...) Also, the kicking and beating of Bosnian refugees by the Serb soldiers."

-d- The above items a, b, and c, however, do not justify participation in separating the male refugees, which exposed them to the real risk of being subjected to torture or inhumane or degrading treatment, or of being executed, for the onset of chaos should not have taken precedence (once the actual purpose of the separation had become known) over facilitating the separation of the men, which resulted in inhumane treatment and executions.

61.7 It has been acknowledged between the parties that, under their supervision, individual Dutchbat soldiers managed to prevent the Bosnian Serbs to remove some men from the corridor to the buses. Accordingly, these male refugees were saved under their supervision. Van Duijn stated about this to the Parliamentary Committee of Inquiry (PCI interviews, p. 31):

"When an old man or a young boy were singled out, too, however, we protested, and this made that we managed to keep a number of people together with their families."

This provides an insufficient basis for facilitating the separation of many (other) male refugees.

61.8 The above leads to the conclusion that ground 42 of the Association et al. succeeds in so far as it is upheld that Dutchbat committed a wrongful act by continuing to supervise the evacuation on 13 July 1995, by putting together groups and forming a 'corridor', whereby Dutchbat facilitated a course of action adopted by the Bosnian Serbs which entailed, as Dutchbat knew or at least should have known, 
the real risk that the male refugees would be exposed to inhumane treatment or execution. Hereafter in this judgment (in 64.1 ff. and 65) the Court of Appeal will address the questions whether it is plausible that the appellants suffered loss as a result, and, in that respect, whether they have an interest in obtaining a declaratory decision.

Evacuation of women, children and the elderly from the compound on 13 July 1995: no wrongful act

62. In answering the question whether Dutchbat should have assisted in the evacuation of the refugees who were in the vehicle hall on 13 July 1995, the question whether the refugees wanted to leave the compound or not may remain unanswered. The Association et al. argued the latter, whereas, on the other hand, it has been established that 'a run on the buses' threatened to ensue when they were leaving the compound, and that conditions for the refugees in the compound were appalling. With regard to departure from the compound, the Court of Appeal considers decisive that Dutchbat could assume in the (late) afternoon of 13 July 1995, like it did, that in the compound 5,000 refugees could not have stayed alive for much longer. As has already been established in 53.2 and 53.3 above, conditions in the compound were appalling without prospects of improvement. Thousands of people were huddled together in a bare concrete hall with little food, water and sanitary facilities at 30 degrees Centigrade, cut off from UN relief convoys. A longer stay of so many people was life-threatening. On the other hand, departure on the buses meant that the women, children and the elderly would reach a safe UN facility. For this reason, Dutchbat was permitted to (and out of necessity: had to) allow the women, children and the elderly to leave the compound to board the buses.

Failure to give the male refugees the choice of staying in the compound: wrongful act

63.1 Ground 4 put forward by the State is directed against the District Court judgment that Dutchbat should have reconsidered its actions when in the (late) afternoon of 13 July 1995 the evacuation of the compound came up, and should not in reasonableness have decided to allow the men to leave the compound (District Court judgment, 4.318-4.329). The State believes that, for several reasons, the case under consideration is distinguished from the other cases tried by the Court of Appeal before in the cases of Nuhanović and Mustafić et al. The Association et al. contested this, stating reasons.

63.2 The Court of Appeal states first and foremost that the question whether or not the evacuation was an uninterrupted process without 'break' between the evacuation of refugees outside the compound and the evacuation of refugees in the compound, as the State argued, can remain unanswered. Irrespective of whether there was such interruption, Dutchbat had sufficient opportunity and control in the vehicle hall to introduce such a break and to warn the men not to walk out with their families. Dutchbat had known since the night before that in the event of evacuation the men ran a real risk due to evacuation of being exposed to inhumane treatment or execution. There were interpreters present in the compound, as well as a people who were on a committee representing the refugees that had been formed on the spot, who could have talked to them and, where necessary, explained things to them. 
63.3 The Court of Appeal disregards the claim put forward by the State that Dutchbat would have had to use force to separate the men from the women, and that such separation would have had 'disastrous consequences' (memorandum of oral pleadings of the State, 2.6). In any case, Dutchbat could have explained the risks and could have (and, as will be considered below: should have) offered them the option of staying in the compound. Relevant in this respect is that no Bosnian Serbs were present in the vehicle hall. Any stir in the crowds would have occurred inside the hall, unnoticed by the Bosnian Serbs as it would have happened indoors.

It must be assumed, considering the serious risk to which the male refugees were exposed in the hands of the Bosnian Serbs, that the men would have stayed behind in the vehicle hall voluntarily (although by necessity and separated from their families) if they had known, like Dutchbat, what was awaiting them outside (separation and the risk of being subjected to inhumane treatment and of being killed).

63.4 The State argued that living conditions in the vehicle hall precluded that refugees stayed in the compound longer. The Court of Appeal has already established above that the living conditions in the compound gave cause for grave concern. This also emerged from Franken's statement referred to in 53.3 above, as well as from the statement referred to by the State (statement of appeal, p. 47) made by Karremans when he was examined as a witness before the District Court in the cases of Nuhanović and Mustafić et al. The fact, however, that there were insufficient supplies of water, food, medication, as well as sanitary facilities to keep 5,000 refugees alive, does not mean unreservedly that there was not enough to keep approximately 350 male refugees on the compound any longer, in addition to the Dutchbat personnel numbering approximately 430 (see 42.2 above) plus local staff, seeing that the male refugees made up a relatively small part of all refugees that had been given shelter in the vehicle halls. Is has been established that there was still (some) drinking water. The procedural documents do not mention an outbreak of any diseases. In light of this the State has not substantiated sufficiently that the lack of water, food, medication and sanitary facilities was acute to such an extent that the State could unreservedly and reasonably decide to also supervise the evacuation of the approximately 350 men as early as 13 July 1995, knowing that the men ran the real risk of being exposed to inhumane treatment and of being executed.

63.5 The State argued insufficiently to rule that if (only) the men had stayed behind in the compound on 13 July 1995, the women, children and the elderly would have been at risk as a result. It has been argued insufficiently to assume - and the Court of Appeal considers it implausible - that if the men had not stepped outside immediately, the Bosnian Serbs would have broken off the evacuation of the women, children and the elderly prematurely (with all the risks that entailed). The Court of Appeal considers relevant in this respect that there is nothing to indicate that the Bosnian Serbs knew that there were still hundreds of men in the vehicle hall whom they would want to separate and deport straight away before they discovered them in the course of the evacuation (in the 'corridor'). It has been established that VRS soldiers carried out an inspection of the hall on 12 July 1995. The VRS soldiers disappeared again after as short tour of the compound (NIOD report p. 2640). It has not been argued (nor has it become evident from any procedural 
document) that they observed anything then about the men amongst the thousands of women and children huddled together. Nor has it been argued (or become evident from the reports) that the Bosnian Serbs on 13 July 1995 carried out an inspection of the vehicle hall from the compound in the course of the evacuation.

63.6 Furthermore, the Court of Appeal considers relevant that if the Bosnian Serbs had known, or had discovered during or after the evacuation that there were men in the compound, and they had stopped the evacuation, Dutchbat could have decided there and then, if necessary, based on the situation that had arisen, including the attitude adopted by the Bosnian Serbs then, whether the men had to leave the compound after all. Dutchbat should not have been predisposed to let the men go, or at least not without explicitly offering them the option, knowing that they would be separated and consequently run the real risk of being subjected to inhumane treatment or being executed. In the opinion of the Court of Appeal there are no grounds to assume that the Bosnian Serbs, upon discovery of over 300 men in the compound, would immediately (without any prior consultation or request to extradite the men after all) have used force of arms against those present in the UN compound. This has not been argued sufficiently by the State, and the Court of Appeal considers such direct military action implausible. In this respect, the Court of Appeal deems relevant that the number of men that would have stayed behind in the compound in this way was relatively small (at most approximately 350, see 42.2 above). Furthermore, the Court of Appeal considers relevant that the Bosnian Serbs had left the compound undisturbed until then, and that they had not fired at UN posts manned by Dutchbat (at least not taking direct aim) until then. Moreover, Dutchbat knew that Mladic had initially said that the refugees would be evacuated in five separate groups, the men after the women and children (see, inter alia, statement of appeal put forward by the Association et al., 160); so in light of this, Dutchbat could have told the Bosnian Serbs that the women and children had been allowed to go first.

63.7 The conclusion is that as Dutchbat knew (on 13 July 1995) that the men upon separation at the evacuation by the Bosnian Serbs ran a real risk of exposure to inhumane treatment or being executed, and that they would probably not arrive in the safe UN shelter facility (unlike the women, children and the elderly), Dutchbat should not have let them go to the buses among the other refugees just like that. Considering the real risk that the men ran outside the compound, Dutchbat should have offered them the option, explicitly and while explaining the risks they would run if they left together with their families, of staying behind inside, while the women, children and the elderly were evacuated from the compound. Dutchbat failed to do so. Nor did Dutchbat try first to keep the men alive in the hall for a couple of days (or even hours) longer in order to gauge the response of the Bosnian Serbs, and to look for any other options for evacuation of the men to a safe area than via the buses of the Bosnian Serbs. Dutchbat let the men go from the vehicle hall and off the compound into the hands of the Bosnian Serbs just like that, in the same way as the other refugees, so by putting together groups who went to the buses through 'the corridor'. By acting in this manner, Dutchbat committed a wrongful act. Ground 4 put forward by the State fails. 
63.8 That the men possibly would not have survived if they had been allowed to stay behind in the vehicle hall, either, is a circumstance that the Court of Appeal will take into consideration in determining whether they incurred a loss as a result of not being given the option of staying behind in the compound on 13 July 1995.

\section{Causal relationship, loss, declaratory decision}

with regard to the male refugees staying in the mini safe area outside the compound on 13 July 1995

64.1 In 61.8 above, the Court of Appeal -contrary to the District Courtestablished that Dutchbat committed a wrongful act by continuing to supervise the evacuation on 13 July 1995 in the mini safe area (occurring outside the compound) by putting together groups and forming a 'corridor', and in doing so facilitating the separation of the male refugees, knowing that the separated men ran a real risk of being exposed to inhumane treatment or of being executed. In view of the devolutive effect of the appeal, the Court of Appeal will now discuss the question whether it is plausible that the Association et al. incurred a loss as a result of this, seeing that the State has disputed this. In this respect, the Court of Appeal finds as follows.

64.2 It has been established that there were Bosnian Serb soldiers near the buses, and that they did not just separate male refugees on their way to the buses, but that they also removed men from the buses along the way and at the destination, and then deported them (see 54.3d above). The Court of Appeal considers plausible, therefore, that these men, who had stayed outside the compound, would also have fallen into the hands of the Bosnian Serbs and been killed if Dutchbat had refrained from acting wrongfully during the evacuation. Against this backdrop, it is the opinion of the Court of Appeal that it is not plausible that these men would have been in better circumstances if Dutchbat had not committed the wrongful act. The causal relationship required for the allocation of damages between the acts performed by Dutchbat and the atrocious fate of the men, is absent, therefore.

64.3 The above considerations entail that the claim for monetary damages of the surviving relatives of the men who stayed outside the compound must be denied. Grounds 42 and 43 put forward by the Association et al. fail in this respect.

65. The fact that the State (Dutchbat), on 13 July 1995 in the presence of the Bosnian Serbs, put together groups of refugees and formed a 'corridor' towards the buses is very grave, as it facilitated a process, as Dutchbat knew or at least should have known by then, that would lead to the men running a real risk of being exposed to inhumane treatment or execution. Dutchbat should have refrained from performing such acts unreservedly, irrespective of the question whether refraining from this facilitation would have resulted in a more favourable outcome for these men, for this concerned the facilitation of acts that were in themselves and irrespective of all other circumstances in violation of Artt. 2 and 3 ECHR. Facilitating the serious violation of these fundamental rights justifies a declaratory decision that a wrongful act was committed, in spite of the fact that no causal relationship has been established. By giving a declaratory decision some kind of redress is given for the violation in which Dutchbat was involved. The Court of 
Appeal will therefore give a declaratory decision that the State committed a wrongful act by facilitating the separation of male refugees on 13 July 1995.

With regard to the male refugees who stayed in the compound on 13 July 1995

66.1 Ground 5 put forward by the State is directed against the District Court judgment that it has been established with a sufficient degree of certainty that the men in the compound would have survived if Dutchbat had not assisted in their deportation (District Court judgment, 4.330-4.332). In this respect, the District Court considered that if the men had stayed behind in the compound, it would effectively have been made impossible for the Bosnian Serbs to take them away without force. The District Court considered to be beyond all reasonable doubt that the Bosnian Serbs would not have resorted to violence. The State believes that the District Court mistakenly disregarded the actual situation and the existing balance of power in and around the compound, and that it is an illusion to think that the Bosnian Serbs would have left the men undisturbed if they had been retained in the compound. The Association et al. disputed the argument stating reasons, and in that connection referred to their responses to the other grounds put forward by the State.

66.2 The Court of Appeal determines that, with hindsight, it cannot be established with a sufficient degree of certainty what would actually have happened to the male refugees if they could have stayed behind in the compound on 13 July 1995. This does not only depend on the actual situation in the compound and on the acts performed by the State (Dutchbat), but (mostly) also on the conduct of the Bosnian Serbs after the evacuation and of their response to retaining the men. With respect to the situation of these male refugees, the Court of Appeal considers as follows.

66.3 The Court of Appeal determines that the Bosnian Serbs would have discovered the retained men soon - and before the evacuation of Dutchbat. The Court of Appeal finds as follows in this connection (66.3a-c)

-a- It has been acknowledged between the parties that after the inspection on 12 July 1995 (referred to in 63.5 above), in any case an inspection of the compound was carried out by the Bosnian Serbs on 15 July 1995, and the NIOD report further mentions an inspection on 13 July 1995 (in the presence of medical officer Schmitz) by the Bosnian Serbs of the injured who had stayed behind in the compound (NIOD report, pp. 2714 and 2766). It can be inferred from the context that this inspection took place when the other refugees had left (local staff and interpreters had to gather in the bar). Oosterveen made a witness statement before the District Court in the case of Mustafic et al. (submitted as exhibit 22 to the rejoinder) that Nicolic (a Serb) came into the compound on 13 or 14 July 1995, as he believed to "check on the wounded". (The question whether the Bosnian Serbs also inspected the compound on 13 July 1995 at 11 a.m., as the State argued and the Association et al. contested in the case under consideration, may remain unanswered, because this inspection would have taken place before the refugees left the compound, and so before the men would have been retained.)

-b- The fact that the inspection of 13 July 1995 occurred on the invitation of Schmitz and Franken, as the Association et al. argued, and, according to the NIOD report (p. 2766) was done because of growing suspicions, does not mean that no inspection would have taken place without this invitation. In those days, it was not 
true that the Bosnian Serbs left UNPROFOR undisturbed and treated UN posts with respect; on the contrary, they showed no respect for Dutchbat and seized observation posts, appropriating vehicles, arms and equipment belonging to the UN (including uniforms and shoes). Nothing prevented the Bosnian Serbs to 'invite' themselves to the compound, as they had done on 12 July 1995 already. In view of the above considerations and of their drive to find Bosnian Muslims (as is demonstrated, inter alia, by their inspections of the buses and of the injured), it is likely that after the evacuation of the refugees an inspection of the compound would have been carried out at some point, with or without the assistance of Dutchbat.

-c- In all likelihood, the Bosnian Serbs would have discovered a group of hundreds of Bosnian Muslim men as a result of their inspection(s) of the compound on 13 July 1995, or at least within a matter of days (no later than 15 July 1995). This group of men would have been discovered before Dutchbat's departure, and could not have left unnoticed together with Dutchbat.

67.1 The question remains whether this group of men, upon discovery, would have been deported by the Bosnian Serbs in second instance. Contrary to what the District Court ruled, in the opinion of the Court of Appeal it is uncertain and cannot be established with a sufficient degree of certainty that the Bosnian Serbs would have left the group of Bosnian Muslim men undisturbed. Ground 5 put forward by the State is well-founded in this respect. The Court of Appeal finds as follows in this connection (a-d).

-a- It emerges from the procedural documents that the Bosnian Serbs had not given the Bosnian Muslims the option of staying in the area: in spite of UNPROFOR presence, the Bosnian Muslims had been chased from the safe area to the mini safe area, and their homes had been burned down in the process. The Bosnian Serbs did not shun the use of physical violence against the refugees. Moreover, general Mladić had just said on 12 July 1995: “They've all capitulated and surrendered and we'll evacuate them all - those who want to and those who don't want to." (See the ICTY judgment in the case against Krstić, referred to by the State in defence on appeal 5.3.13).

-b- It is uncertain whether (and for how long) Dutchbat could have stopped the Bosnian Serbs if the latter had wanted to force the male refugees from the compound. There is nothing to indicate that Dutchbat could have protected the men against the Bosnian Serbs on 13 July 1995 (and shortly thereafter). In this respect, not only Dutchbat's situation, but also the strategy of the Bosnian Serbs is relevant. It was a known fact that they did not shun disarming UNPROFOR soldiers and taking them hostage. It is uncertain with how many troops and equipment they could have mobilised at the compound around 13 July 1995. Even if the Court of Appeal assumes that there were 300 combat soldiers in the compound, and no Dutchbat soldier had surrendered any more arms since 12 July 1995, it is likely that the Bosnian Serbs could have outnumbered Dutchbat and the refugees. On the other hand, however, there are reasons to believe that sparing the blue helmets was part of their attack strategy (NIOD report p. 2439, District Court judgment in 4.331).

-c- The Bosnian Serbs were also capable of preventing UN relief convoys to get through and thus cut off supplies to the compound (see 48.2 and $53.2 \mathrm{ff}$. above). In view of the already dire living conditions in the compound as a result of scarcity, the 
blocking of supplies could eventually have made it untenable not to comply with the demand of the Bosnian Serbs to evacuate. It is uncertain whether and to what extent the Bosnian Serbs would have resorted to this means of exerting pressure, as it would have endangered the lives of UN soldiers as well. Until then, the Bosnian Serbs had left the UN soldiers in the compound undisturbed and had spared their lives.

-d- For the same reasons as considered by the Court of Appeal in 44.2 above with respect to reoccupying the enclave, it is uncertain whether the international community could have intervened in due time if the Bosnian Serbs had wanted to remove the male refugees from the compound by force. If it had been possible at all to mobilize close air support or even air strikes before living conditions in the compound had become absolutely untenable, close air support or air strikes could well have been hard to implement locally because with an attack on the Bosnian Serbs the UN compound (including Dutchbat and the refugees) could easily have been hit as well.

67.2 In the event that the Bosnian Serbs had allowed the men to stay in the compound with Dutchbat, in spite of their earlier intention to evacuate everyone and remove the men, it has to be assumed also that the men would have been brought to safety somehow eventually, via diplomatic channels, just like the UN and MSF personnel, as was found by the District Court (District Court judgment, in 4.334) and not contested on appeal. Therefore, the Court of Appeal does not need to discuss whether the men, if they had been left undisturbed by the Bosnian Serbs until Dutchbat's departure, and had not died of hunger, thirst or exhaustion, would have survived: this has been acknowledged between the parties.

68. As indicated in 66.1 above, the District Court found that it has been established with a sufficient degree of certainty that the men would have survived if they had been retained in the compound (District Court judgment, in 4.330). The Court of Appeal does not concur with this. It is too uncertain on the basis of all considerations above what would have happened to allocate $100 \%$ liability for damage. The Court of Appeal cannot establish either, however, that the men's chance of survival was so small as to be negligible. In this connection, the Court of Appeal considers in particular that the Bosnian Serbs had left the UN soldiers in the compound undisturbed until then, as it observed in 67.1c above already. All things considered, the Court of Appeal determines the chance that the men would have escaped inhumane treatment and execution by the Bosnian Serbs if they had been able to stay in the UN compound at $30 \%$. By not offering the men the choice of staying in the compound - with explanation of the risks they would run on leaving the compound - on 13 July 1995, the State (Dutchbat) deprived them of this chance.

69.1 The above means that the surviving relatives of the men who stayed in the compound on 13 July 1995 are entitled to a compensation of their loss in proportion to the chance that these men would have escaped to safety if Dutchbat had not acted wrongfully, that is $30 \%$ of the loss incurred. In so far as the State contested in its ground 5 that he is liable to compensate the loss, the ground fails.

69.2 The Court of Appeal (like the District Court) will not order the State to pay an advance on the damages awarded to appellants 1 through 10 , because their husbands were not evacuated from the compound on 13 July 1995. 
70. With respect to the invocation of Article 6:99 DCC (within the context of ground 43 put forward by the Association et al.), the Court of Appeal notes that it has been established that the death of the men is a direct consequence of the acts performed by the Bosnian Serbs, and that without the acts of the Bosnian Serbs the men would certainly not have been executed. By its acts during the evacuation, Dutchbat facilitated the separation of the men, after which the inhumane treatment and executions could take place. The Association et al. have not adduced sufficient arguments in these proceedings, however, to rule that without Dutchbat committing a wrongful act, one (or more) of the men would have stood a better chance of not being subjected to inhumane treatment and execution. The invocation of Art. 6:99 DCC does not succeed, therefore.

71.1 The District Court also ruled that the liability of the State is limited to the family members of the men who were deported from the compound by the Bosnian Serbs on 13 July 1995 and subsequently killed, by whom are meant the wives and children of the adult men, and the parents of the underage children (District Court judgment in 4.339). Ground 46 put forward by the Association et al. is directed against this.

71.2 Under Dutch law the obligation to compensate loss in the event of death is limited by, inter alia, Article 6:108 DCC. This limitation does not restrict the circle of persons entitled to compensation to family members or spouses, parents and underage children; other relatives or members of the family for whom the deceased provided maintenance can also claim damages. The District Court therefore ruled wrongly that the liability of the State (only) extended to the family members. Ground 46 put forward by the Association et al. succeeds, therefore.

72. Ground 44 put forward by the Association et al. has been discussed above sufficiently (inter alia in paragraphs 44) and must be rejected. Grounds 45, 47, and 48 put forward by the Association et al. do not raise new views and do not need further discussion.

\section{Conclusion}

73.1 The conclusion is that grounds $26,27,28,42$, and 46 of the appeal put forward by the Association et al., and grounds 3 and 5 put forward by the State are well-founded or partially well-founded, and that all other grounds must be rejected.

73.2 The (partial) upholding of ground 42 put forward by the Association et al. entails that the Court of Appeal, contrary to the District Court, rules that after the Bosnian Serb soldiers arrived in the morning of 13 July 1995, Dutchbat should have stopped facilitating - by breaking the refugees down into smaller groups and creating a 'corridor' - the Bosnian Serbs to separate the male refugees after which they were exposed to the real risk of inhumane treatment and execution. No (financial) compensation can be awarded for this, due to the absence of a cause-andeffect relationship between these actions and the inhumane treatment and execution of the men. Declaratory relief must be given by way of remedy, however. Furthermore, the Court of Appeal rules, like the District Court, that Dutchbat should not have allowed the male refugees to be evacuated from the compound unreservedly. The (partial) upholding of ground 5 by the State entails that the Court of Appeal, contrary to the District Court, rules that these actions conducted by 
Dutchbat denied the male refugees who were inside the compound on 13 July 1995 a $30 \%$ chance of escape from the inhumane treatment and executions.

73.3 As the Court of Appeal pronounces a declaratory judgment that differs from the District Court's, it quashes the District Court's ruling.

\section{Completion of the assessment on appeal}

74. In the State's statement of defence (under 2.1.4) and at the hearing it was asserted that the NIOD would carry out an exploratory (supplementary) investigation with regard to the decision-making about granting close air support and prior knowledge about an attack on the safe area Srebrenica. From newspaper articles published since it has become manifest to the Court of Appeal that this survey by the NIOD led to no further investigation at the moment due to lack of new information. The Court of Appeal overlooks this argument of supplementary investigation, therefore, as was discussed with the parties at the hearing beforehand.

75. As both parties on appeal succeeded in some and failed in other claims, the Court of Appeal orders that each party will have to pay its own costs in both cases, in first instance and in the principal and cross-appeals.

\section{Ruling}

\section{In both cases}

In the principal and the cross-appeal

The Court of Appeal:

- sets aside the contested District Court's judgment and in a new judgment

- rules that the State acted wrongfully I. by facilitating the separation of the male refugees by the Bosnian Serbs on 13 July 1995 by letting the refugees go to the buses in groups and through 'the corridor',

and II. by not offering the male refugees who were inside the compound on 13 July 1995 the choice to stay within the compound, thereby denying them the $30 \%$ chance of not being exposed to inhumane treatment and executions by the Bosnian Serbs;

- orders the State to pay damages for the loss and suffering sustained referred to under II, to be assessed and settled in accordance with the law, and declares this judgment immediately enforceable;

- dismisses all other applications made on appeal.

- orders each party to pay its own legal costs in first instance and on appeal.

This judgment was given in open court by Justices G. Dulek-Schermers, S.A. Boele and E.M. Dousma-Valk on 27 June 2017, in the presence of the clerk of the court.

\section{References}

Bakker C (2013) Dual attribution of acts committed by a UN peacekeeping force: an emerging norm of customary international law? The Dutch Supreme Courts Judgments in Nuhanović and Mustafić. Ital Yearb Int Law 23:287-297

d'Argent P (2014) State organs placed at the disposal of the UN, effective control, wrongful abstention and dual attribution of conduct. Quest Int Law/Questioni di diritto internazionale 1:17-31 
Dannenbaum $\mathrm{T}$ (2015) Dual attribution in the context of military operations. Int Organ Law Rev 12:401-426

Krieger H (2015) Addressing the accountability gap in peacekeeping: law-making by domestic courts as a way to avoid UN reform? NILR 62:259-277

Negishi Y (2017) The pro homine principle's role in regulating the relationship between conventionality control and constitutionality control. EJIL 28(2):457-481

Nollkaemper PA (2011) Dual attribution: liability of the Netherlands for conduct of Dutchbat in Srebrenica. J Int Crim Justice 9:1143-1157

Nollkaemper PA, Jacobs D (2012-2013) Shared responsibility in international law: a conceptual framework. Mich J Int Law 34:359-438

Noyes JE, Smith BD (1988) State responsibility and the principle of joint and several liability. Yale J Int Law 13(2):225-267

Saul B (2009) The implementation of the Genocide Convention at the national level. In: Gaeta P (ed) The UN Genocide Convention: a commentary. Oxford University Press, Oxford, pp 58-83

Schabas WA (2009) Genocide: the crime of crimes, 2nd edn. Cambridge University Press, Cambridge 